Prepared in cooperation with the

CITY OF WICHITA, KANSAS, as part of the Equus Beds Ground-Water

Recharge Project

\title{
Geochemical Effects of Induced Stream-Water and Artificial Recharge on the Equus Beds Aquifer, South-Central Kansas, 1995-2004
}

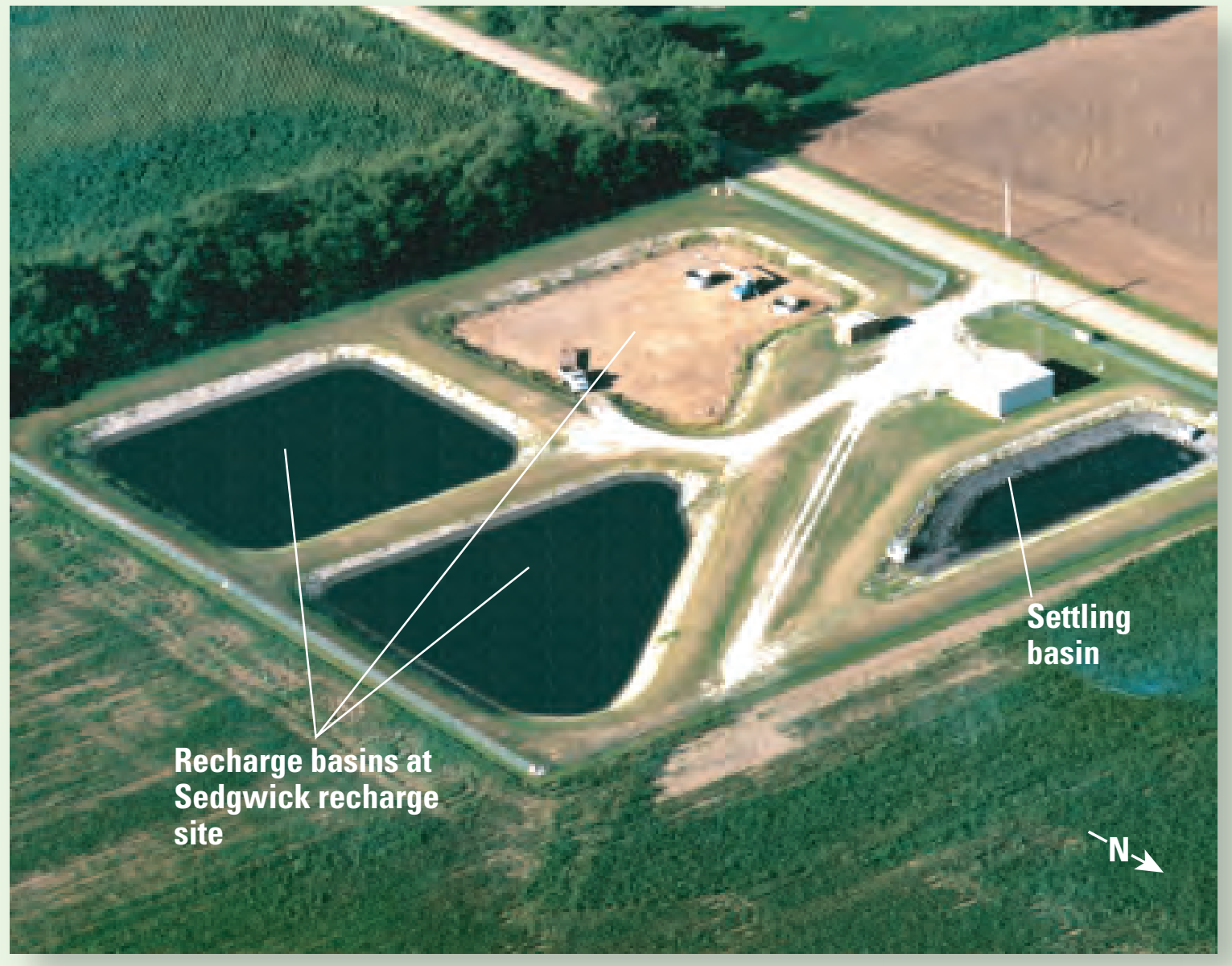

Scientific Investigations Report 2007-5025 



\section{Geochemical Effects of Induced Stream- Water and Artificial Recharge on the Equus Beds Aquifer, South-Central Kansas, 1995- 2004}

By Heather C. Ross Schmidt, Andrew C. Ziegler, and David L. Parkhurst

Prepared in cooperation with the

CITY OF WICHITA, KANSAS, as part of the

Equus Beds Ground-Water Recharge Project

Scientific Investigations Report 2007-5025 


\title{
U.S. Department of the Interior DIRK KEMPTHORNE, Secretary
}

\author{
U.S. Geological Survey \\ Mark D. Myers, Director
}

\section{U.S. Geological Survey, Reston, Virginia: 2007}

For product and ordering information:

World Wide Web: http://www.usgs.gov/pubprod

Telephone: 1-888-ASK-USGS

For more information on the USGS--the Federal source for science about the Earth, its natural and living resources, natural hazards, and the environment:

World Wide Web: http://www.usgs.gov

Telephone: 1-888-ASK-USGS

Any use of trade, product, or firm names is for descriptive purposes only and does not imply endorsement by the U.S. Government.

Although this report is in the public domain, permission must be secured from the individual copyright owners to reproduce any copyrighted materials contained within this report.

Suggested citation:

Schmidt, H.C. Ross, Ziegler, A.C., and Parkhurst, D.L., 2007, Geochemical effects of induced stream-water and artificial recharge on the Equus Beds aquifer, south-central Kansas, 1995-2004: U.S. Geological Survey Scientific Investigations Report 2007-5025, 58 p.

Front cover: Aerial photograph of Sedgwick recharge site (taken by Dave Stous, Burns and McDonnell Engineering Consultants, 1997).

Back cover: Photograph of recharge basins at Halstead recharge site (taken by Dave Stous, Burns and McDonnell Engineering Consultants, 1997). 


\section{Contents}

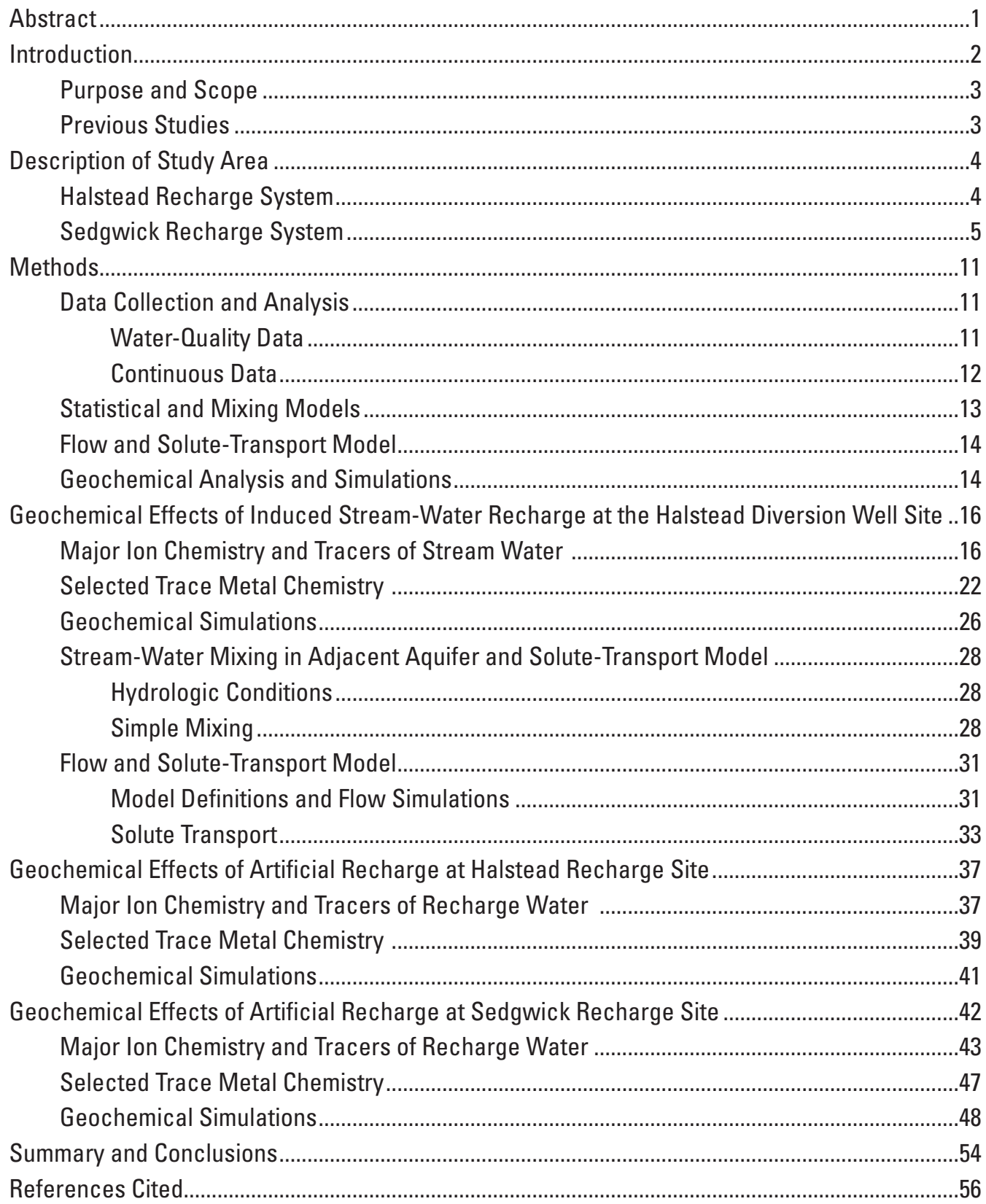

\section{Figures}

1. Maps showing location of study area in south-central Kansas

2. Maps showing features of Halstead recharge system including Halstead diversion well site and Halstead recharge site...................................................................................

3. Hydrogeologic section showing lithology at Halstead diversion well site .........................8

4. Hydrogeologic section showing lithology at Halstead recharge site ...............................9

5. Map showing features of Sedgwick recharge site .....................................................10

6. Hydrogeologic section showing lithology at Sedgwick recharge site ...........................11 
7. Graph showing relation between chloride concentrations and streamflow in Little Arkansas River at Highway 50 near Halstead during demonstration recharge period, April 1996-June 2002.

8. Graph showing estimated chloride concentrations in the Little Arkansas River at Highway 50 near Halstead using regression models based on streamflow and specific conductance measurements compared to measured chloride concentrations in water samples from the Little Arkansas River, 1995-2004

9. Piper diagrams describing major ion chemistry of water samples from monitoring wells and diversion well water at the Halstead diversion well site during March 1996, July 1996, June 2001, and May 2003.

10-16. Graphs showing:

10. Measured and estimated chloride concentrations in water samples from Little Arkansas River at Highway 50 near Halstead and from monitoring wells and diversion well water at Halstead diversion well site, February 1995-December 2004

11. Relation between chloride concentrations and specific conductance measurements in water from the diversion well at Halstead diversion well site, February 1995-May 2002

12. Measured and estimated atrazine concentrations in water from Little Arkansas River at Highway 50 near Halstead and from monitoring wells and diversion well water at Halstead diversion well site, February 1995-December 2004.

13. Measured and estimated arsenic concentrations in water samples from Little Arkansas River at Highway 50 near Halstead and from monitoring wells and diversion well water at Halstead diversion well site, February 1995-December 2004

14. Arsenic, iron, and manganese concentrations in deep monitoring well EB-145-PD5 at Halstead diversion well site, February 1995-December 2004........26

15. Iron concentrations in water samples from Little Arkansas River at Highway 50 near Halstead and from monitoring wells and diversion well water at Halstead diversion well site, February 1995-December 2004

16. Water-level altitudes in monitoring wells at Halstead diversion well site and in Little Arkansas River at Halstead for November 1995-December 2004 and for January 2004-December 2004.

17. Piper diagrams showing median major ion chemistry in water samples from Little Arkansas River at Highway 50 near Halstead, diversion well, and shallow monitoring well EB-145-A5 at the Halstead diversion well site

18. Computer screen capture showing model grid for the flow and solute-transport model at the Halstead diversion well site

19. Maps showing simulated water-level contours for the upper and lower parts of the aquifer adjacent to the Little Arkansas River at the Halstead diversion well site. .34

20. Graphs showing simulated and measured water-level response to pumping at the Halstead well site .... .35

21. Computer screen capture showing initial chloride distribution for solute-transport model at the Halstead diversion well site.

22. Graph showing simulated fraction of stream chloride concentration in Halstead diversion well over a 100 -year simulation

23. Piper diagrams showing major ion chemistry in water samples from the Halstead recharge site in May 1997, May 1999, and April 2003. 
24-27. Graphs showing:

24. Chloride concentrations in ground-water samples from the diversion well at Halstead diversion well site and monitoring wells at Halstead recharge site, May 1997-December 2004

25. Atrazine concentrations in ground-water samples from diversion well water at Halstead diversion site and monitoring wells at Halstead recharge site compared to concentrations in diverted recharge water, May 1997-December 2004............42

26. Arsenic concentrations in ground-water samples from diversion well water at Halstead diversion site and monitoring wells at Halstead recharge site compared to concentrations in diverted recharge water, May 1997-December 2004............43

27. Iron concentrations in ground-water samples from diversion well water at Halstead diversion site and monitoring wells at Halstead recharge site compared

to concentrations in diverted recharge water, May 1997-December 2004 . .44

28. Piper diagrams showing major ion chemistry in water samples from the Sedgwick recharge site in July 1997, May 1999, and August 2002

29-33. Graphs showing:

29. Measured and estimated chloride concentrations in water samples from Little Arkansas River near Sedgwick, treated diverted stream water, and monitoring wells at the Sedgwick recharge site, February 1995-December 2004.

30. Atrazine concentrations in water samples from Little Arkansas River near Sedgwick, treated diverted stream water, and monitoring wells at the Sedgwick recharge site, February 1995- December 2004

31. Arsenic concentrations in water samples from Little Arkansas River near Sedgwick, treated diverted stream water, and monitoring wells at the Sedgwick recharge site, February 1995-December 2004

32. Iron concentrations in water samples from Little Arkansas River near Sedgwick, treated diverted stream water, and monitoring wells at the Sedgwick recharge site, February 1995-December 2004

33. Saturation indices for calcite and amorphous iron oxide, and modeled $\mathrm{pH}$ for theoretical mixing model of artificial recharge by injection of treated stream water into the Equus Beds aquifer.

\section{Tables}

1. Description of data-collection sites for Equus Beds Ground-Water Recharge Project, south-central Kansas, 1995-2004

2. Results of analysis of atrazine degradation products in water samples from the Little Arkansas River, from monitoring wells, and the diversion well at the Halstead diversion well site, south-central Kansas, 1995-2004.

3. Saturation indices calculated for ground-water samples collected from Halstead diversion well site, south-central Kansas, March 1995-July 2003.

4. Saturation indices calculated for ground-water samples collected from monitoring wells at Halstead recharge site and Halstead diversion well, south-central Kansas, May 1997-April 2003.

5. Saturation indices calculated for ground-water samples collected from monitoring wells at Sedgwick recharge site and for samples of treated diverted stream water, south-central Kansas, July 1997-April 2003. 


\section{Conversion Factors, Abbreviations, and Datums}

\begin{tabular}{lll}
\hline \multicolumn{1}{c}{ Multiply } & By & \multicolumn{1}{c}{ To obtain } \\
\hline inch (in.) & Length & \\
foot (ft) & 2.54 & centimeter $(\mathrm{cm})$ \\
mile $(\mathrm{mi})$ & 0.3048 & meter $(\mathrm{m})$ \\
meter $(\mathrm{m})$ & 1.609 & kilometer $(\mathrm{km})$ \\
yard $(\mathrm{yd})$ & 3.28 & foot $(\mathrm{ft})$ \\
\hline & 0.9144 & meter $(\mathrm{m})$ \\
\hline acre & Area & \\
square mile $\left(\mathrm{mi}^{2}\right)$ & 4,047 & square meter $\left(\mathrm{m}^{2}\right)$ \\
& 2.590 & square kilometer $\left(\mathrm{km}^{2}\right)$ \\
\hline cubic foot per second $\left(\mathrm{ft}{ }^{3} / \mathrm{s}\right)$ & Flow rate & \\
foot per day $(\mathrm{ft} / \mathrm{d})$ & 0.02832 & cubic meter per second $\left(\mathrm{m}^{3} / \mathrm{s}\right)$ \\
gallon per minute $(\mathrm{gal} / \mathrm{min})$ & 0.3048 & meter per day $(\mathrm{m} / \mathrm{d})$ \\
inch per year $(\mathrm{in} / \mathrm{yr})$ & 0.06309 & liter per second $(\mathrm{L} / \mathrm{s})$ \\
\hline & 2.54 & centimeters per year $(\mathrm{cm} / \mathrm{yr})$ \\
\hline gallon $($ gal $)$ & Volume & \\
micrograms per liter $(\mu \mathrm{g} / \mathrm{L})$ & 0.003785 & cubic meter $\left(\mathrm{m}^{3}\right)$ \\
milligrams per liter $(\mathrm{mg} / \mathrm{L})$ & 1.0 & part per billion $(\mathrm{ppb})$ \\
million gallons $(\mathrm{Mgal})$ & 1.0 & part per million $(\mathrm{ppm})$ \\
\hline
\end{tabular}

Temperature in degrees Celsius $\left({ }^{\circ} \mathrm{C}\right)$ may be converted to degrees Fahrenheit $\left({ }^{\circ} \mathrm{F}\right)$ as follows:

$$
{ }^{\circ} \mathrm{F}=\left(1.8 x^{\circ} \mathrm{C}\right)+32 .
$$

Temperature in degrees Fahrenheit $\left({ }^{\circ} \mathrm{F}\right)$ may be converted to degrees Celsius $\left({ }^{\circ} \mathrm{C}\right)$ as follows:

$$
{ }^{\circ} \mathrm{C}=\left({ }^{\circ} \mathrm{F}-32\right) / 1.8 \text {. }
$$

Specific conductance is reported in microsiemens per centimeter at 25 degrees Celsius $(\mu \mathrm{S} / \mathrm{cm}$ at $\left.25^{\circ} \mathrm{C}\right)$.

\section{Datums}

Vertical coordinate information is referenced to the North American Vertical Datum of 1988 (NAVD 88).

Horizontal coordinate information is referenced to the North American Datum of 1983 (NAD 83).

Altitude, as used in this report, refers to distance above the vertical datum. 


\title{
Geochemical Effects of Induced Stream-Water and Artificial Recharge on the Equus Beds Aquifer, South- Central Kansas, 1995-2004
}

\author{
By Heather C. Ross Schmidt, Andrew C. Ziegler, and David L. Parkhurst
}

\section{Abstract}

Artificial recharge of the Equus Beds aquifer is part of a strategy implemented by the city of Wichita, Kansas, to preserve future water supply and address declining water levels in the aquifer of as much as 30 feet caused by withdrawals for water supply and irrigation since the 1940s. Water-level declines represent a diminished water supply and also may accelerate migration of saltwater from the Burrton oil field to the northwest and the Arkansas River to the southwest into the freshwater of the Equus Beds aquifer.

Artificial recharge, as a part of the Equus Beds GroundWater Recharge Project, involves capturing flows larger than base flow from the Little Arkansas River and recharging the water to the Equus Beds aquifer by means of infiltration or injection. The geochemical effects on the Equus Beds aquifer of induced stream-water and artificial recharge at the Halstead and Sedgwick sites were determined through collection and analysis of hydrologic and water-quality data and the application of statistical, mixing, flow and solute-transport, and geochemical model simulations.

Chloride and atrazine concentrations in the Little Arkansas River and arsenic concentrations in ground water at the Halstead recharge site frequently exceeded regulatory criteria. During 30 percent of the time from 1999 through 2004, continuous estimated chloride concentrations in the Little Arkansas River at Highway 50 near Halstead exceeded the Secondary Drinking-Water Regulation of 250 milligrams per liter established by the U.S. Environmental Protection Agency. Chloride concentrations in shallow monitoring wells located adjacent to the stream exceeded the drinking-water criterion five times from 1995 through 2004. Atrazine concentrations in water sampled from the Little Arkansas River had large variability and were at or near the drinking-water Maximum Contaminant Level of 3.0 micrograms per liter as an annual average established by the U.S. Environmental Protection Agency. Atrazine concentrations were much smaller than the drinking-water criterion and were detected at much smaller concentrations in shallow monitoring wells and diversion well water located adjacent to the stream probably because of sorption on aquifer sediment. Before and after artificial recharge, large, naturally occurring arsenic concentrations in the recharge water for the Halstead diversion well and recharge site exceeded the Maximum Contaminant Level of 10 micrograms per liter established by the U.S. Environmental Protection Agency for drinking water. Arsenic and iron concentrations decreased when water was recharged through recharge basins or a trench; however, chemical precipitation and potential biofouling eventually may decrease the artificial recharge efficiency through basins and trenches.

At the Sedgwick site, chloride concentrations infrequently exceeded regulatory criteria. Large concentrations of atrazine were treated to decrease concentrations to less than regulatory criteria. Recharge of treated stream water through recharge basins avoids potentially large concentrations of arsenic and iron that exist at the Halstead diversion site.

Results from a simple mixing model using chloride as a tracer indicated that the water chemistry in shallow monitoring well located adjacent to the Little Arkansas River was 80 percent of stream water, demonstrating effective recharge of the alluvial aquifer by the stream. Results also indicated that about 25 percent of the water chemistry of the diversion well water was from the shallow part of the aquifer. Additionally, diverting water through a diversion well located adjacent to the stream removed about 75 percent of the atrazine, probably through sorption to aquifer sediment, and decreased the need for additional water treatment to remove atrazine.

A flow and solute-transport model was developed using water-level and chloride concentration data to simulate and better evaluate the quantity of stream-water flow to the pumping diversion well. Simulation results indicate that chloride concentrations in the diversion well are dependent on the chloride distribution in the aquifer during the first few years of pumping. About 75 percent of the water in the diversion well originates from stream water after long-term continuous pumping for decades.

A theoretical geochemical model was developed to simulate the effects of artificially recharging fully oxygenated, treated stream water, by injection into the aquifer. Results indicate that chemical precipitation of calcite and iron oxyhydroxide are likely to occur and the potential increase of iron bacteria may combine to cause reduced efficiency of injection wells. 


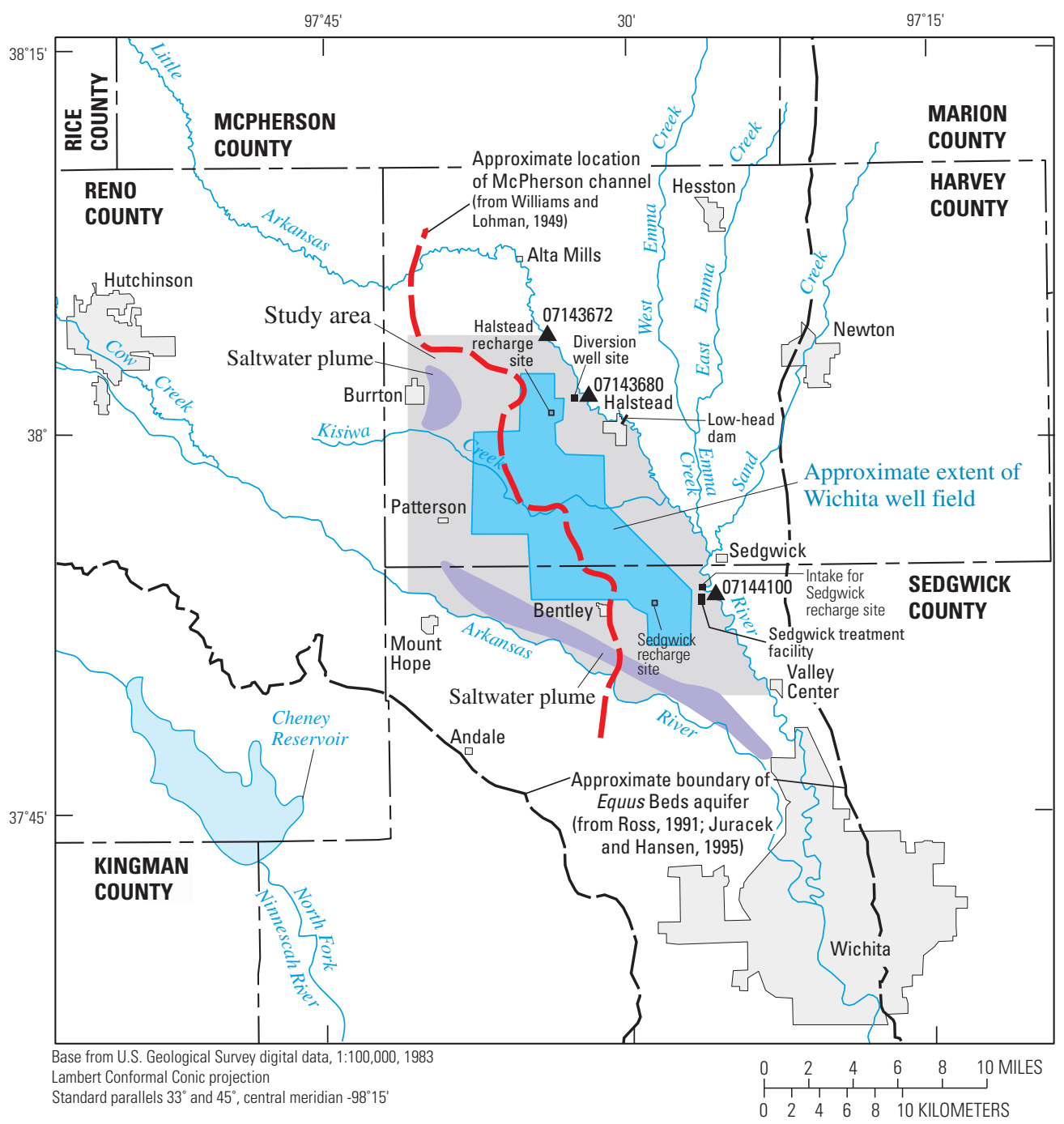

EXPLANATION

${ }^{07144100}$ U.S. Geological Survey stream-gaging station and number
Index map

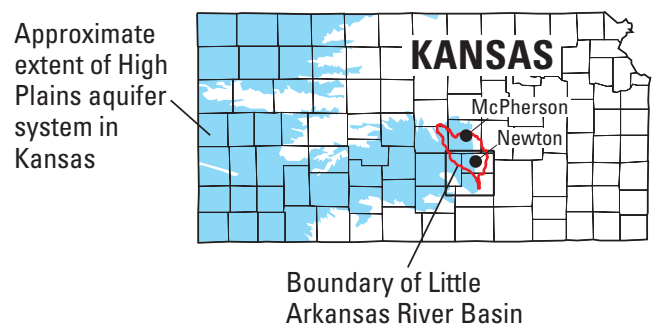

Figure 1. Location of study area in south-central Kansas.

\section{Introduction}

The Wichita well field, developed in the 1940s in the Equus Beds aquifer, is one of the primary sources of water for the city of Wichita and the surrounding area in south-central Kansas (fig. 1). Historical water use for municipal supply and irrigation have caused water levels in the Equus Beds aquifer to decline more than $30 \mathrm{ft}$ by 1993 in some areas (Aucott and others, 1998). Water-level declines represent a diminished water supply and also may accelerate migration of saltwa- ter from the Burrton oil field to the northwest and from the Arkansas River to the southwest into the freshwater of the Equus Beds aquifer (Myers and others, 1996).

Cheney Reservoir was first used in 1965 to supplement Wichita's water supply from the Wichita well field (fig. 1). From 1965 through the mid-1990s, the city of Wichita's water supply consisted of a mixture of 40 percent water from Cheney Reservoir and 60 percent water from the Equus Beds aquifer (Warren and others, 1995). Water-supply withdrawals were revised in the mid-1990s to use reservoir water for 
a larger percentage of the drinking-water supply because of declining water levels in the Equus Beds aquifer. Since 1993, ground-water levels have recovered more than $20 \mathrm{ft}$ in some areas of the Wichita well field, primarily because of increased water use from Cheney Reservoir and decreased pumping in the well field area (Hansen and Aucott, 2004). In 2003, water from Cheney Reservoir was used for 60 percent of the water supply for the city of Wichita (Joan Kenny, U.S. Geological Survey, written commun., January 28, 2005). However, an expected increase in demand could cause supply shortages in the future (2050) (Jerry Blain, Water Supply Projects Administrator, city of Wichita Water and Sewer Department, oral commun., 2005).

Artificial recharge of the Equus Beds aquifer will be used to augment the city of Wichita's future water supply and help to preserve all existing aquifer uses from degradation by saltwater migration from the Burrton oil field and the Arkansas River by increasing water levels in the aquifer (fig. 1). Artificial recharge, as a part of the Equus Beds Ground-Water Recharge Project, involves capturing streamflows larger than base flow from the Little Arkansas River and recharging the water to the Equus Beds aquifer by means of infiltration or injection. The Equus Beds aquifer is recharged naturally by precipitation, subsurface inflow, streamflow losses, and irrigation return flow (Myers and others, 1996). Precipitation recharge, the major source of natural recharge for the Equus Beds aquifer, is estimated to be approximately $3 \mathrm{in} / \mathrm{yr}$ (Hansen, 1991).

Artificial recharge adds a larger volume of water to the aquifer over a shorter period of time than would occur with natural infiltration. Artificially recharged water, however, may not have time to equilibrate to the existing ground-water chemical composition. Potential effects of artificial recharge include altering the $\mathrm{pH}$ and (or) dissolved oxygen concentration of the water, which could affect the solubility and mobility of ions important to water quality, such as calcium, bicarbonate, arsenic, and iron. Changes in dissolved oxygen could increase or decrease bacterial activity and potentially increase iron concentrations. Increased bacterial activity can create biofilms that reduce the effectiveness of artificial recharge. Dissolution of aquifer material can release constituents, such as arsenic, into ground water. Precipitation of minerals could reduce the size of aquifer pores, which could result in slower flow velocities through and smaller storage volumes in the aquifer (Drever, 1997).

A demonstration project for the Equus Beds GroundWater Recharge Project was conducted from April 1995 through May 2002 to determine the feasibility of proposed artificial recharge methods, as well as to determine the effects of artificial recharge on the water quality of the aquifer. Different methods of capturing and recharging flows larger than base flow in the Little Arkansas River were used in two different recharge systems. The Halstead recharge system consisted of a diversion well, operated only when adjacent streamflows were larger than base flow, and a recharge facility $2 \mathrm{mi}$ away where recharge water from the diversion well was distributed to surface-spreading basins, a recharge trench, or an injection well.
In the Sedgwick recharge system, flows greater than base flow were diverted directly from the Little Arkansas River. The water then was treated and artificially recharged to the aquifer through surface-spreading recharge basins.

The Equus Beds Ground-Water Recharge Project is a cooperative effort between the city of Wichita and the U.S. Geological Survey (USGS). The USGS role in the cooperative study is to document changes in historic hydrologic and water-quality conditions, identify probable causes of the changes in the study area, and define pre-recharge conditions for evaluating the effects of artificial recharge related to water quantity and water quality. Additional participants in the study are the Equus Beds Groundwater Management District No. 2 (Halstead, Kansas), Bureau of Reclamation (U.S. Department of Interior), and the U.S. Environmental Protection Agency (USEPA). Project work is coordinated with the Kansas Department of Health and Environment (KDHE), the Kansas Water Office, and the Kansas Department of Agriculture, Division of Water Resources. Burns and McDonnell Engineering Consultants (Kansas City, Missouri) and Mid-Kansas Engineering Consultants (Wichita, Kansas) provide engineering expertise and project management. The maintenance and operation of the recharge facilities are performed by the city of Wichita.

\section{Purpose and Scope}

This report describes the geochemical effects of induced stream-water recharge at the Halstead diversion site and artificial recharge on part of the Equus Beds aquifer at the Halstead and Sedgwick recharge sites. Effects of induced stream-water recharge through a pumping well at the Halstead diversion well site are described by analyses of water levels, water chemistry of stream and recharge water, a simple chloride-based mixing model to estimate the percentage of stream water in the adjacent aquifer over time, and a flow and solute-transport model to estimate the amount of stream water in the diversion well.

Water-quality data collected during 1995-2004 from ground- and stream-water sites were used to describe the geochemical effects of artificial recharge processes. Changes in water chemistry as well as the multifunctional geochemical model PHREEQC (Parkhurst and Appelo, 1999) were used to describe geochemical processes caused by artificial recharge. Methods described in this report can be applied to similar recharge studies in other parts of the United States and foreign lands with similar hydrologic conditions.

\section{Previous Studies}

This report is one of several that are based upon the extensive data set collected as part of the Equus Beds GroundWater Recharge Project. Two previous reports presented results that are pertinent to the study described in this report. The first water-quality summary report, "Baseline Water Quality and Preliminary Effects of Artificial Recharge on Ground 
Water, South-Central Kansas, 1995-98" (Ziegler and others, 1999) presented results that indicate the initial effects of artificial recharge were minimal, that the water types involved in the recharge process were compatible, and that the primary constituents of concern for artificial recharge were chloride and atrazine because of generally larger concentrations of these constituents in stream water when compared to native ground water. Chloride and atrazine also were identified as constituents of concern because concentrations of these constituents in the stream water exceeded USEPA regulatory criteria. Other potential constituents of concern were sodium, nitrite plus nitrate, iron, manganese, and total coliform bacteria.

A second water-quality summary report "Effects of Artificial Recharge on Water Quality in the Equus Beds Aquifer, South-Central Kansas, 1995-2000" (Ziegler and others, 2001) found that the overall effects of 3 years of artificial recharge did not substantially change ground-water quality. The report identified chloride, atrazine, total coliform bacteria, and additionally arsenic, as constituents of concern for recharge activities. Arsenic concentrations in the recharge water at Halstead ranged from 16 to $24 \mu \mathrm{g} / \mathrm{L}$. Pre-artificial recharge arsenic concentrations in samples from monitoring wells at the Halstead recharge site ranged from less than 1 to $11 \mu \mathrm{g} / \mathrm{L}$, and larger dissolved arsenic concentrations likely came from aquifer material (Ziegler and others, 2001). Arsenic was not included in the 1999 report because the USEPA Maximum Contaminant Level (MCL) for drinking water in 1999 was $50 \mu \mathrm{g} / \mathrm{L}$, and arsenic concentrations in water sampled as a part of the artificial recharge demonstration project did not approach $50 \mu \mathrm{g} / \mathrm{L}$ (Ziegler and others, 2001). In 2001, USEPA revised the arsenic MCL for finished drinking water to $10 \mu \mathrm{g} / \mathrm{L}$, effective in January 2006 (U.S. Environmental Protection Agency, 2004), and as a result, arsenic became a constituent of concern for artificial recharge.

\section{Description of Study Area}

The study area for the Equus Beds Ground-Water Recharge Project encompasses approximately $165 \mathrm{mi}^{2}$ and extends northwest of the city of Wichita across parts of Harvey and Sedgwick Counties in south-central Kansas (fig. 1). The study area is bounded by the Arkansas River on the southwest and the Little Arkansas River on the northeast. The drainage area for the Little Arkansas River Basin near Sedgwick (site 07144100) is about 1,165 $\mathrm{mi}^{2}$ (Ziegler and others, 1999).

South-central Kansas has a continental climate that is characterized by large variations in seasonal temperatures, moderate precipitation, and windy conditions (Hansen and Aucott, 2004). In Wichita, Kansas, long-term daily average temperatures for $1971-2000$ range from $30.2^{\circ} \mathrm{F}$ in January to $81.0^{\circ} \mathrm{F}$ in July (National Oceanic and Atmospheric Administration, 2002). The long-term annual mean precipitation for 1940-2005 at weather stations near the study area (at Halstead, Hutchinson, Mount Hope, Newton, Sedgwick, and Wichita) is 31.35 in. (National Oceanic and Atmospheric Administration, 1998-2005b). Most of this precipitation commonly occurs during spring and summer (May-September) (Hansen and Aucott, 2004).

Land use in the Little Arkansas River Basin is primarily agricultural and includes the production of livestock (pasture and rangeland) and field crops. Field crops produced include corn, sorghum, soybeans, and wheat (U.S. Department of Agriculture, 2002a,b). Agricultural chemicals applied to enhance crop production in the basin include fertilizers (such as nitrate, ammonia, and phosphorus) and pesticides (primarily alachlor and atrazine).

The Equus Beds aquifer, the easternmost extension of the larger High Plains aquifer system, consists of unconsolidated silt, clay, sand, and gravel deposits of Quaternary age (Williams and Lohman, 1949). The Equus Beds aquifer includes alluvium adjacent to the streams in the study area. The McPherson channel (fig. 1), a trough of unconsolidated deposits about $200 \mathrm{ft}$ thick within the Equus Beds aquifer, is a major flow path for ground-water movement within the aquifer and is important as it relates to the movement of chemical constituents (Williams and Lohman, 1949).

The Equus Beds aquifer is an important source of ground water for the area because of generally shallow depth to the water table, large saturated thickness, and generally good water quality (Hansen and Aucott, 2004). Near the Arkansas River, the water table may be as little as $10 \mathrm{ft}$ below land surface. Near the Little Arkansas River, the water table is at a greater depth, depending on the altitude of the land surface and the amount of water-level decline that has been caused by ground-water withdrawals. The maximum saturated thickness of the Equus Beds aquifer within the study area (almost $250 \mathrm{ft}$ ) is near the Arkansas River and corresponds to the deepest areas of the underlying bedrock surface (Myers and others, 1996).

The direction of ground-water movement in the Equus Beds aquifer generally is to the east (Aucott and others, 1998). The Little Arkansas River primarily is a gaining stream within the study area as indicated by higher water levels in wells adjacent to the stream, which causes discharge from the aquifer to the stream during base-flow conditions (Myers and others, 1996; Aucott and others, 1998). However, in the vicinity of the Halstead diversion well site, a low-head dam on the river (fig. 1) has caused river elevation to be higher than water levels in the adjacent alluvium resulting in constant recharge of water from the Little Arkansas River to the aquifer (Ziegler and others, 1999).

\section{Halstead Recharge System}

The Halstead recharge system consists of the streamgaging station and water-quality monitoring site on the Little Arkansas River at Highway 50 near Halstead (site 07143672, fig. 1), a river-stage monitoring site on the Little Arkansas 
River at Halstead (site 07143680, fig. 2A), the Halstead diversion well site (fig. $2 A$ ), and the Halstead recharge site (fig. $2 B$ ). During the demonstration phase of the recharge project, in accordance with Kansas Department of Agriculture, Division of Water Resources, permit conditions, the recharge water was diverted by pumping the diversion well adjacent to the Little Arkansas River only when flow exceeded $42 \mathrm{ft}^{3} / \mathrm{s}$ at the upstream stream-gaging station (site 07143672, fig. 1) from April 1 through September 30 and when flow exceeded $20 \mathrm{ft}^{3} / \mathrm{s}$ from October 1 through March 31 (Burns and McDonnell, written commun., 1998). Recent permit approval for Phase I of the full-scale artificial recharge and storage project (August 2005) by the Kansas Department of Agriculture, Division of Water Resources, requires minimum streamflow in the Little Arkansas River at Highway 50 near Halstead of $57 \mathrm{ft}^{3} / \mathrm{s}$ from April through September and $20 \mathrm{ft}^{3} / \mathrm{s}$ from October through March (Kansas Department of Agriculture, Division of Water Resources, written commun., August 2005).

The Halstead diversion well site includes five shallow monitoring wells identified as EB-145-A1 through EB-145-A5, one deep monitoring well EB-145-PD5, and a pumping (diversion) well (table 1). The depths of the shallow wells range from 43 to $70 \mathrm{ft}$ below land surface, and the wells are located approximately 45 to $1,600 \mathrm{ft}$ from the river. Observation wells EB-145-PD3 and EB-145-PS3 (table 1, fig. 3) were used during aquifer tests conducted by Burns and McDonnell Concultants, Kansas City, Missouri, at the site and were not used for water-quality sampling. They are included in this report to describe the lithology at the site. All wells are constructed of 2-in. diameter polyvinyl chloride (PVC) and generally are screened in the lower $10 \mathrm{ft}$ of the casing. The string of shallow wells trends in a southwest line that is roughly perpendicular to the stream at the site (fig. 2A). The deep monitoring well (EB-145-PD5) at the site is completed at a depth of approximately $120 \mathrm{ft}$ and is located approximately $60 \mathrm{ft}$ from the river. The deep monitoring well is screened over the lowest $5 \mathrm{ft}$ of the well casing. The diversion well is a pumping well located approximately $150 \mathrm{ft}$ north of the string of monitoring wells, and the depth of the well is approximately $136 \mathrm{ft}$. The diversion well is located approximately $70 \mathrm{ft}$ from the Little Arkansas River. The pumping capacity of the diversion well is about $1,000 \mathrm{gal} / \mathrm{min}$, and the well is screened throughout the lower $60 \mathrm{ft}$ of the casing (table 1).

Well logs indicate that the lithology at the diversion well site consists primarily of sand deposits interbedded with clay layers of varying thicknesses (fig. 3). A discontinuous clay layer occurs approximately $50 \mathrm{ft}$ below land surface at the diversion well site. The clay layer extends laterally beneath the Little Arkansas River to the west (Burns and McDonnell, written commun., 1998) and pinches out between monitoring well EB-145-A2 and EB-145-A3 to the west (fig. 3). Where present, the lower permeability clay slows vertical movement of water from the upper part into the lower part of the aquifer. Although this clay layer alters direct flow of stream water into the lower part of the aquifer, it does not inhibit it entirely, and there is connectivity between the upper and lower parts of the aquifer (Burns and McDonnell, written commun., 1998).

Recharge water from the diversion well was pumped about $2 \mathrm{mi}$ through a pipeline to the Halstead recharge site where it was artificially recharged into the Equus Beds aquifer by one of three methods-surface-spreading recharge basins, a recharge trench, or a direct injection well (fig. $2 B$ ). Two recharge basins at the Halstead site are each capable of initially recharging 60 to $80 \mathrm{ft} / \mathrm{d}$ into the aquifer (Burns and McDonnell, written commun., 2005). However, a clay layer with some sand approximately $30 \mathrm{ft}$ below land surface at the recharge site impedes vertical flow of recharge water into the aquifer (Ziegler and others, 1999) (fig. 4). This impediment caused water to rise to the bottom of the recharge basins, which resulted in lateral flow and slowed percolation through these basins to about 1 to $2 \mathrm{ft} / \mathrm{d}$. The addition of passive recharge wells (2-in. well completed through the clay layer) increased infiltration rates to 6 to $8 \mathrm{ft} / \mathrm{d}$ (Burns and McDonnell, written commun., 2005). A recharge trench was installed by the city of Wichita to promote vertical movement of recharge water into the aquifer. The recharge trench is $100 \mathrm{ft}$ long, $3 \mathrm{ft}$ wide, and approximately $15 \mathrm{ft}$ deep; it has been tested at recharge rates of 60 to $80 \mathrm{ft} / \mathrm{d}$ (Burns and McDonnell, written commun., 2005). In addition, a direct injection well was used to recharge water into the lower part of the Equus Beds aquifer. The injection well is $225 \mathrm{ft}$ deep and is capable of recharging about $900 \mathrm{gal} / \mathrm{min}$ to the aquifer. The vertical-flow problems associated with recharge basins at the site do not affect the injection well because the recharge water is injected beneath the clay layer.

At the Halstead site, two shallow monitoring wells (SMW-H4 and SMW-H14) are completed at depths of 29 and $27 \mathrm{ft}$, respectively; the wells are screened in the lowermost $10 \mathrm{ft}$ of the well casing. Two deep monitoring wells (DMW$\mathrm{H} 1$ and DMW-H13) also are located at the site and are completed to a depth of $220 \mathrm{ft}$. Deep monitoring wells H1 and H13 are screened from 210 to $220 \mathrm{ft}$ below land surface (table 1).

Artificial recharge began at the Halstead recharge site on May 29, 1997, and was discontinued in May 2002 when the demonstration phase of the Equus Beds Ground-Water Recharge Project ended. Almost $930 \mathrm{Mgal}$ of water were recharged at the Halstead recharge site during the demonstration project (Burns and McDonnell, written commun., 2002).

\section{Sedgwick Recharge System}

The Sedgwick recharge system consists of the streamgaging and water-quality-monitoring site in the Little Arkansas River near Sedgwick (site 07144100), a treatment facility, and the Sedgwick recharge site (fig. 1). For the Sedgwick recharge system, Kansas Department of Agriculture, Division of Water Resources, permit conditions allow water to be withdrawn from the river at all times when streamflow exceeds $40 \mathrm{ft}^{3} / \mathrm{s}$ at site 07144100 (Burns and McDonnell, written commun., 1998). 
(A)

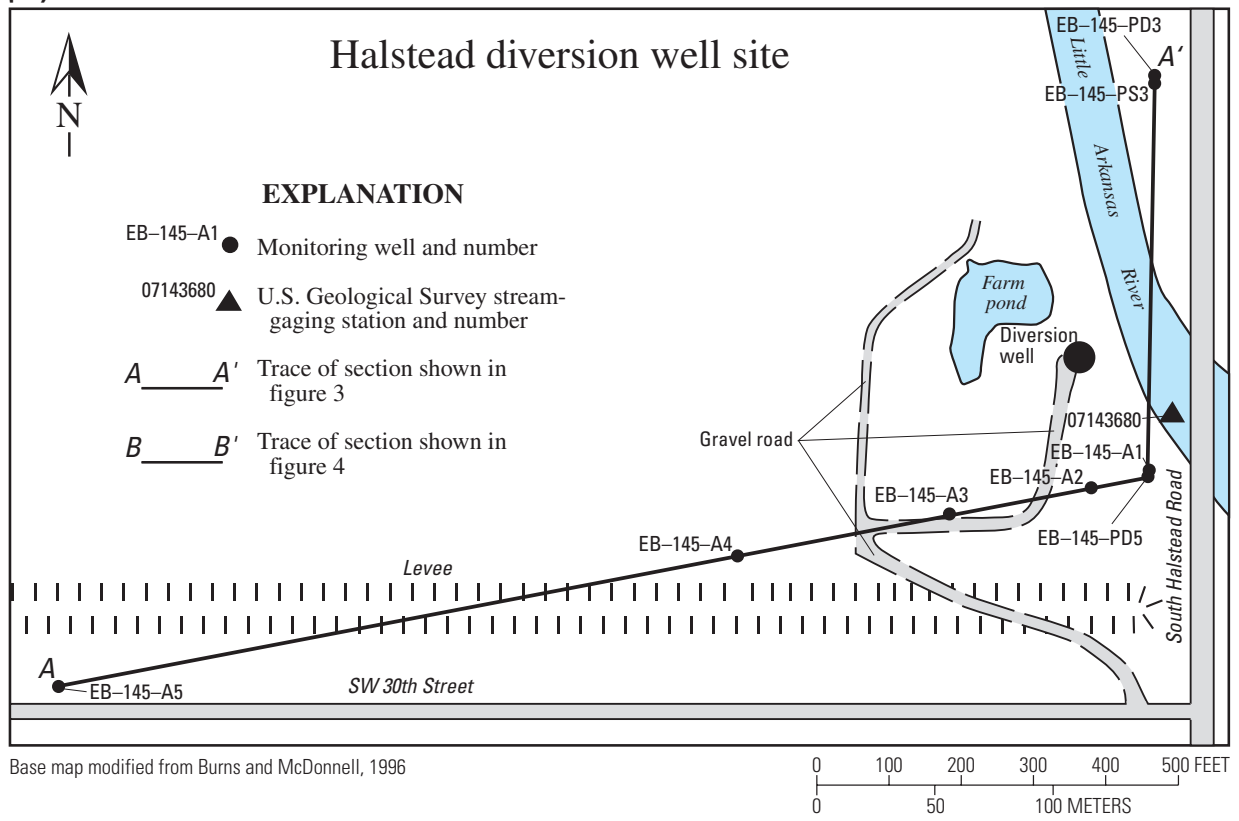

(B)

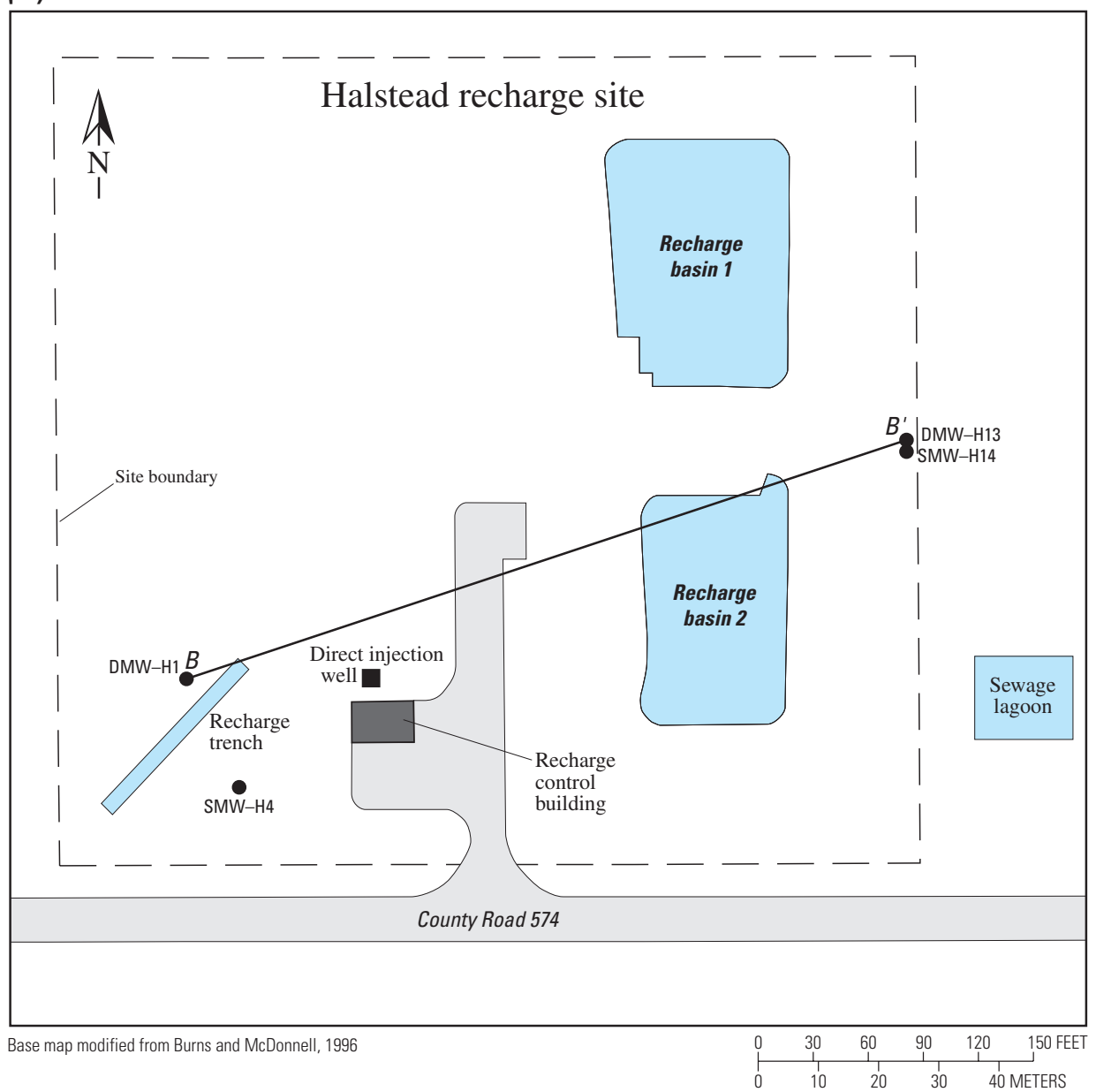

Figure 2. Features of Halstead recharge system including $(A)$ Halstead diversion well site and (B) Halstead recharge site. 


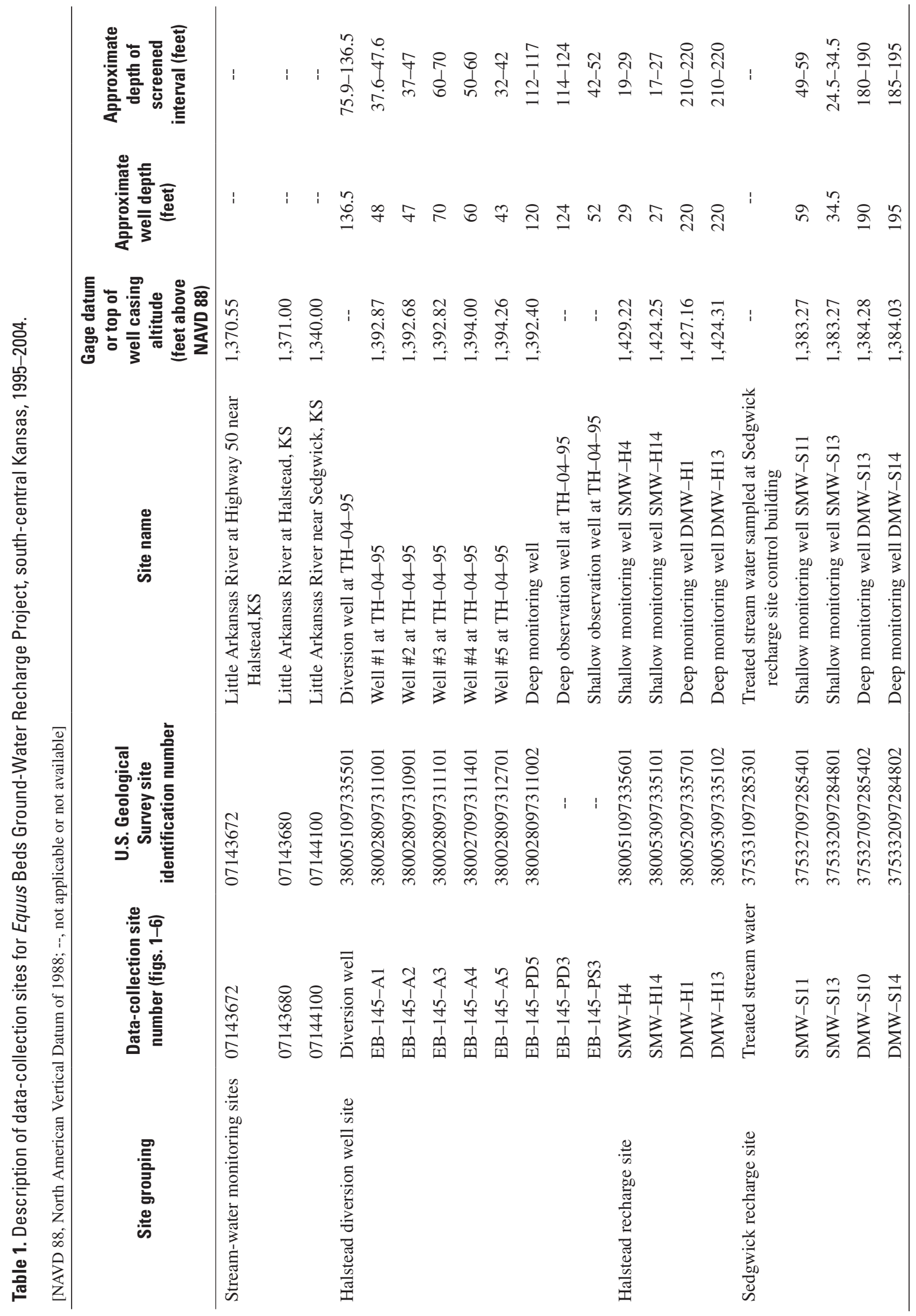




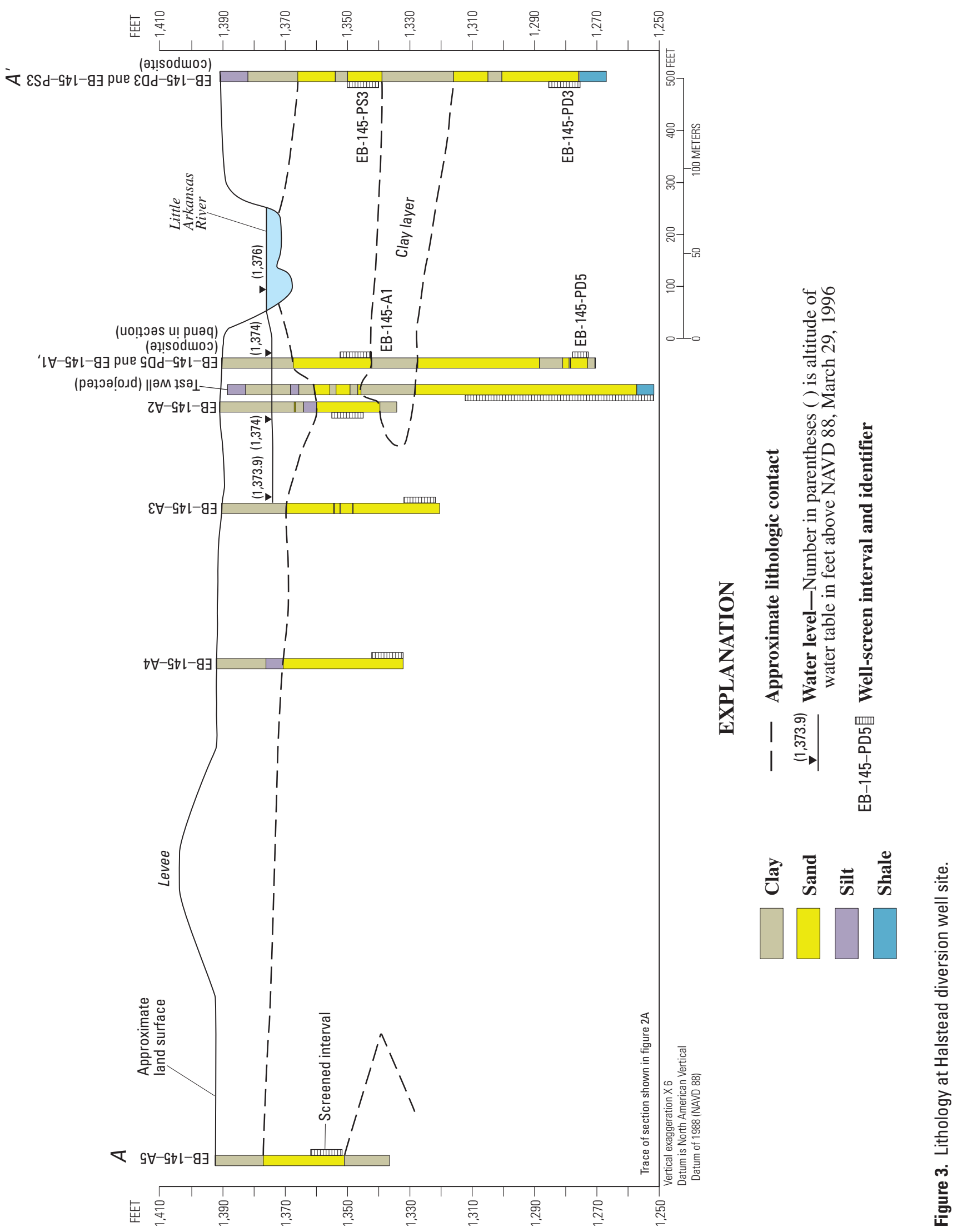




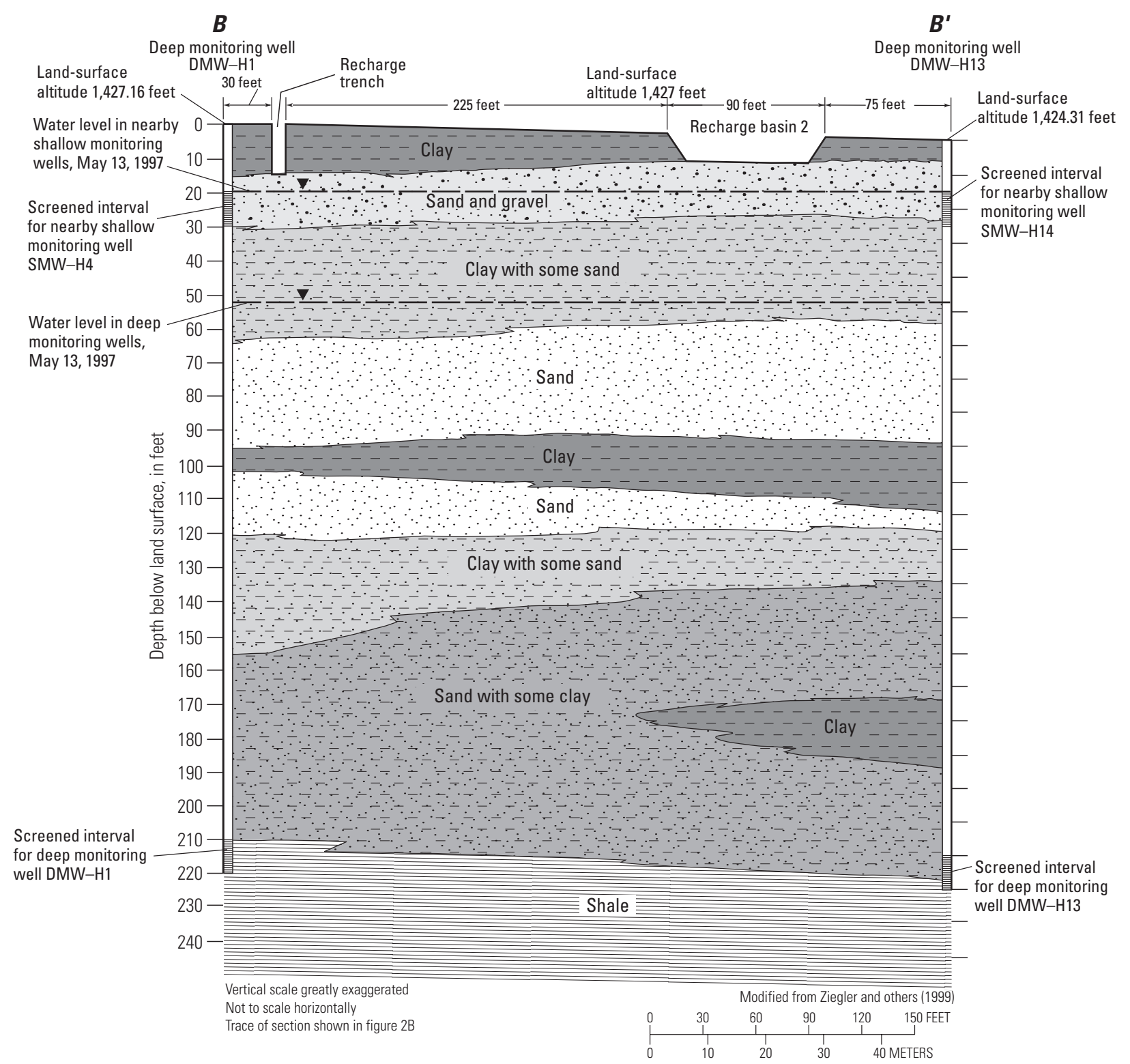

Figure 4. Lithology at Halstead recharge site.

Recharge water in the Sedgwick recharge system was diverted directly from the Little Arkansas River. After the water was diverted from the stream, it was treated with coagulants to remove sediment. Then, powdered activated carbon (PAC) was added to remove atrazine and other organic compounds from the water. After treatment, the water was pumped about $2 \mathrm{mi}$ to the Sedgwick recharge site.

At the Sedgwick recharge site (fig. 5), the treated stream water was pumped to a settling basin to allow the remaining suspended sediment and PAC to settle out of the water. From the settling basin, treated stream water was pumped to one of three surface-spreading recharge basins and allowed to infiltrate into the Equus Beds aquifer. Shallow clay layers are not present to impede vertical movement of recharge water at this location; therefore, flow of recharge water to the water table occurs rapidly (fig. 6). Water levels in the shallow (wells SMW-S11 and SMW-S13) and deep (wells DMWS10 and DMW-S14) monitoring wells are the same and indicate hydraulic connection between the upper sand-and-gravel layers and the lower layers at the Sedgwick site. Infiltration rates through the recharge basins at this site averaged 8 to $9 \mathrm{ft} / \mathrm{d}$ (Burns and McDonnell, written commun., 2005). Large permeability values of the sand-and-gravel layer underlying the recharge basins contribute to rapid infiltration.

Artificial recharge at the Sedgwick recharge site began in April 1998 and continued through 2000. Approximately $136 \mathrm{Mgal}$ of treated stream water were artificially recharged to the aquifer at the Sedgwick recharge site (Burns and McDonnell, written commun., 2002). Artificial recharge activities ended in 2000 as the demonstration phase of the Equus Beds Ground-Water Recharge Project ended at the Sedgwick site. 


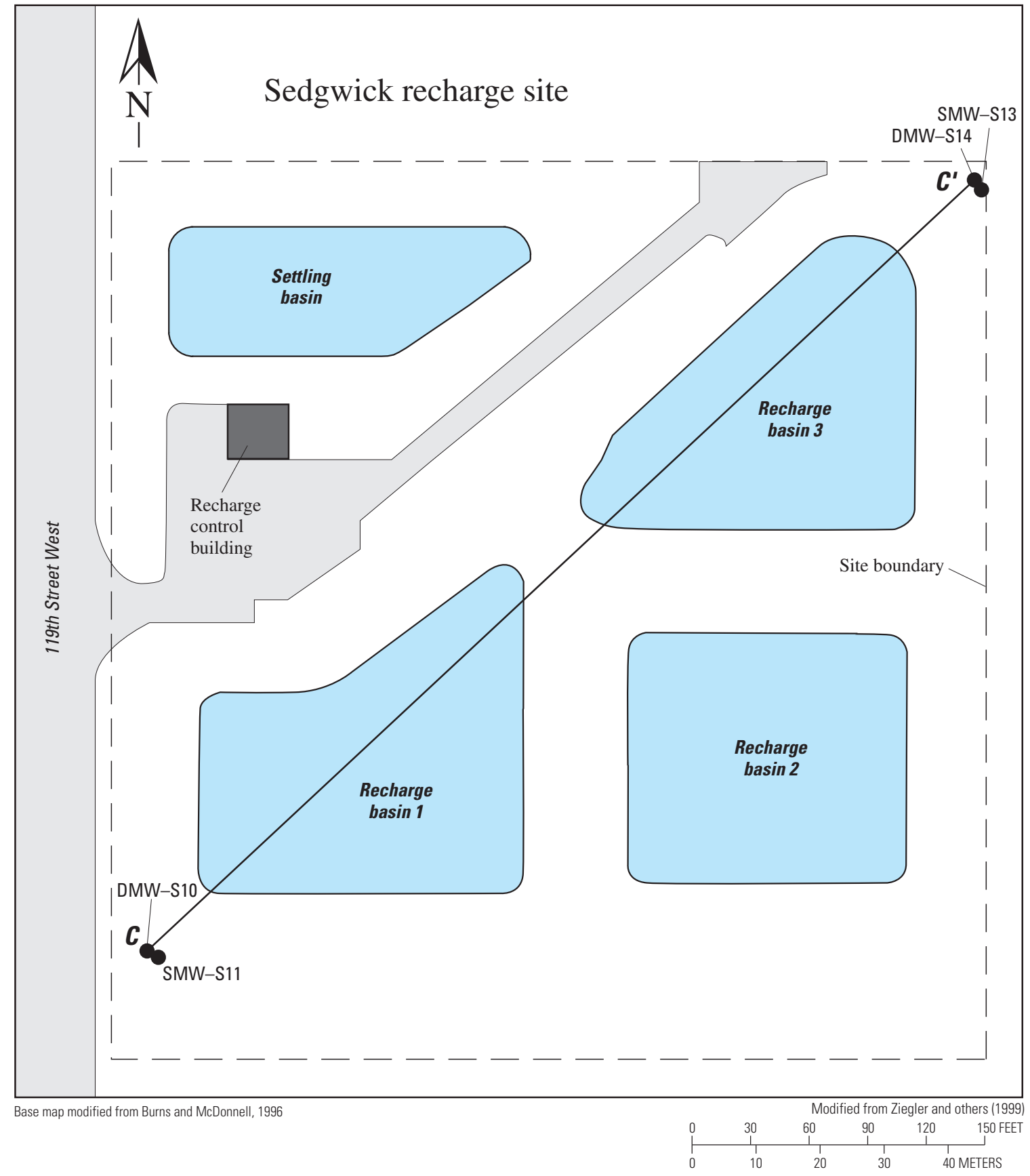

EXPLANATION

DMW-S10 Monitoring well and number

$\underline{C} \quad C^{\prime}$ Trace of section shown in figure 6

Figure 5. Features of Sedgwick recharge site. 


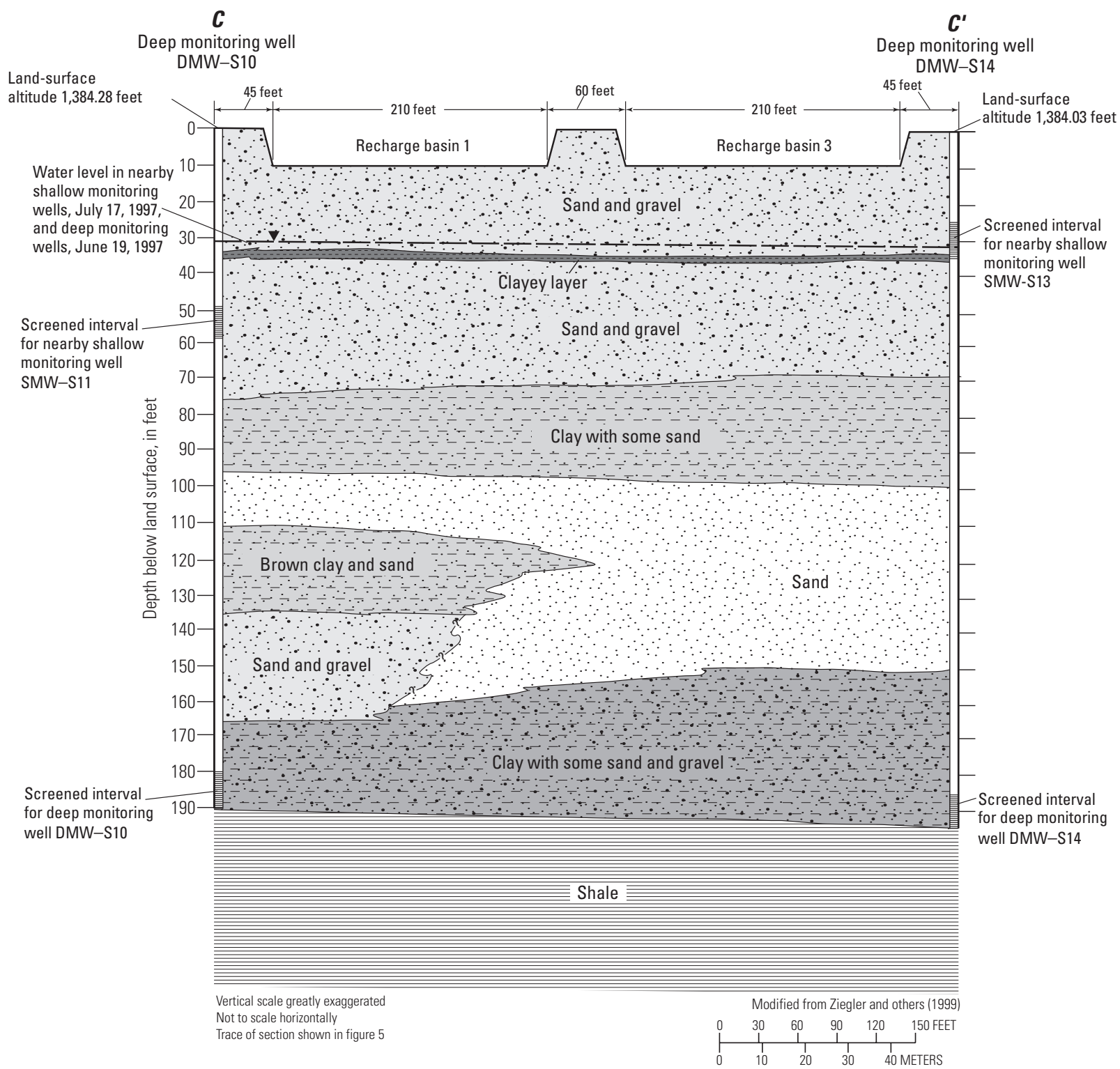

Figure 6. Lithology at Sedgwick recharge site.

\section{Methods}

\section{Data Collection and Analysis}

Discrete water-quality samples as well as continuous water-quality, water-level, and streamflow data were used in this report to describe the geochemical effects of artificial recharge activities. Discrete water-quality samples were collected at monitoring well sites, at the diversion well, from treated diverted stream water from the settling basin at the Sedgwick recharge site, and at two stream-water sites on the Little Arkansas River. Real-time continuous water-quality data were collected at the Little Arkansas River at Highway 50 near Halstead and at Sedgwick stream-gaging sites (07143672, 07144100, fig. 1).

\section{Water-Quality Data}

Discrete stream- and ground-water-quality samples were collected from February 1995 through August 2004 throughout the study area. Stream-water samples were collected using depth- and width-integrating techniques (Wilde and Radtke, 1998). Ground-water samples were collected with a submersible pump using methods described in Wood (1976), Koterba and others (1995), and Puls and Barcelona (1996).

Analyses of water samples were performed to determine concentrations of dissolved solids, total and dissolved inorganic constituents, nutrients, organic compounds, volatile organic compounds (VOCs), radionuclides, and fecal-indicator bacteria in water samples (Ziegler and Combs, 1997). Arsenic speciation data also were collected and analyzed using methods described in Garbarino and others (2002). Dissolved concentrations of major ions; calcium, magnesium, sodium, 
potassium, chloride, sulfate, and bicarbonate; trace metals; arsenic and its species; iron; and the organic compound, atrazine, are discussed in this report to describe the geochemical effects of artificial recharge. A discussion of all constituents sampled as a part of the Equus Beds Ground-Water Recharge Demonstration Project is included in Ziegler and others (1999). Samples were analyzed by the city of Wichita laboratory (Wichita, Kansas), the USGS National Water-Quality Laboratory (Denver, Colorado), and the USGS Organic Geochemistry Research Laboratory (Lawrence, Kansas).

Atrazine concentrations in water samples for this study were determined by enzyme-linked immunosorbent assay (ELISA), which is a screen for triazine compounds that include atrazine, cyanazine, propazine, and their degradation products. In addition, selected samples were confirmed as atrazine by gas chromatography/mass spectrometry (GC/MS) at the USGS Organic Geochemistry Research Laboratory, Lawrence, Kansas. The relation between triazine herbicide concentrations determined by ELISA and atrazine concentrations determined by GC/MS for water collected from the Little Arkansas River is expressed by the equation:

$$
y=0.81 x,
$$

where $x$ is the triazine herbicide concentration and $y$ is the atrazine concentration (Ziegler and others, 1999). This relation between triazine and atrazine concentrations indicates that atrazine made up 81 percent of triazine concentrations. For the purposes of this report, triazine compounds detected by ELISA methodology will be referred to as atrazine.

Discrete water-quality samples were collected at least monthly from two stream-water sites on the Little Arkansas River from 1995 through 2003. In 2004, eight samples per stream-water site were collected from March through July. Water-quality samples were collected at least quarterly from all monitoring wells at the Halstead and Sedgwick recharge sites and from selected monitoring wells at the Halstead diversion well site. Water from the diversion well was sampled at least monthly while in operation. The treated stream water at the Sedgwick recharge site also was sampled at least monthly during active artificial recharge activities.

Further information regarding data-collection methods, preservation, sample holding times, analytical methods, and reporting limits can be found in Ziegler and Combs (1997). A description of the data-collection sites used in this study is provided in table 1. Data used for analysis in this report are available on the Web at http://waterdata.usgs.gov/ks/nwis/qw. Statistical summaries of water-quality data are available at http://ks.water.usgs.gov/Kansas/studies/equus/ (accessed December 2006).

Replicate, blank, and standard reference samples were quality-control samples collected as a part of the Equus Beds artificial recharge project. More than 200 quality-control samples were collected from 1995 through 2004; the majority of these samples were replicate and blank samples. Replicate samples were collected to identify the variability in the sampling and analysis system (Wilde and Radtke, 1998). A replicate sample set is a set of two (or more) samples that are collected closely in time and space so that the sample sets are thought to be representative of the ambient water composition at one collection time (Wilde and Radtke, 1998). More than 100 replicate samples were collected from 1995 through 2004. Replicate samples were compared with their respective original sample by relative percentage difference (RPD) between the two samples. RPDs were calculated as the difference between the replicate and original sample concentrations divided by the average of the two values, multiplied by 100 . Generally, replicate samples had RPDs of 10 percent or less and indicated that sampling and analysis methods were consistent and did not introduce large variability into the data set.

More than 90 blank samples were collected as a part of the Equus Beds artificial recharge project from 1995 through 2004. Dissolved solids and sodium were detected in 10 percent of the blank samples at concentrations greater than 5 and $1 \mathrm{mg} / \mathrm{L}$, respectively. Fluoride was detected in 15 percent of the blank samples. The detections of sodium were small and probably because of impurities in the acid used to the preserve the samples. Fluoride detections in blank samples ranged from 0.04 to $0.10 \mathrm{mg} / \mathrm{L}$, and fluoride detected in environmental samples ranged from less than 0.02 to $0.82 \mathrm{mg} / \mathrm{L}$; therefore, fluoride concentrations in environmental samples could be affected by sampling and analytical errors.

Standard reference samples were analyzed by the Wichita Municipal Water and Wastewater Laboratory on an annual basis and submitted to the USGS Branch of Quality Systems for analysis of results and evaluation of laboratory performance. A laboratory rating is assigned for each sample type and overall. Ratings are based on the number of F-pseudosigmas the reported value is from the most probable value (MPV), which is defined as the Z-value. A rating of excellent to unsatisfactory is assigned depending on the range of the $\mathrm{Z}$-value. Absolute $\mathrm{Z}$-value ranges from 0.00 to 0.50 were excellent, 0.51 to 1.00 were good, 1.01 to 1.50 were satisfactory, 1.51 to 2.00 were marginal, and greater than 2.00 were unsatisfactory (U.S. Geological Survey, 2006). Evaluations of the Wichita laboratory were consistently good to excellent in major and minor ion analysis. However, nutrient analysis was rated marginal during some years of the Equus Beds artificial recharge project. Results are available on the Web at http:// bqs.usgs.gov/srs/.

\section{Continuous Data}

Data from continuous stream-gaging stations, continuous real-time water-quality monitors, and pressure transducers installed in monitoring wells to record real-time ground-water levels were used along with discrete-sample analytical data to aid in the interpretation of results presented in this report. Real-time monitoring of streamflow in the Little Arkansas River at Sedgwick stream-gaging site (07144100) began in October 1993. The stream-gaging site on the Little Arkansas River at Highway 50 near Halstead (site 07143672) began real-time monitoring of streamflow in May 1995. Real-time 
monitoring of river stage and nearby monitoring wells began in October 1995 at the Little Arkansas River at Halstead stream-gaging site (07143680).

Continuous real-time monitoring of specific conductance, $\mathrm{pH}$, and temperature using a multiparameter water-quality monitor began in May 1998 at the Little Arkansas River at Highway 50 near Halstead stream-gaging site (07143672) and in April 1998 at the Sedgwick stream-gaging site (07144100). Dissolved oxygen and turbidity sensors were added to the water-quality monitors at both sites in October 1998. Waterquality sensors were calibrated and maintained according to methods presented in Wilde and Radke (1998) and Wagner and others (2000).

Pressure transducers were installed to record near realtime ground-water levels in monitoring wells EB-145-A1, A2, A3, and A4 in October 1995. Pressure transducers were installed in monitoring well EB-145-A5 in November 1995 and in well EB-145-PD5 in February 1996. Realtime ground-water levels were recorded in monitoring wells EB-145-A2, A3, A4 and A5 through March 2002. Groundwater levels were recorded in monitoring wells EB-145-A1 and EB-145-PD5 through December 2004.

Streamflow, water-level, and water-quality data were transmitted by satellite to a downlink site and to a computer at the USGS Kansas Water Science Center in Lawrence, Kansas. Data are available upon request, and daily values are available on the Web at http://waterdata.usgs.gov/ks/nwis/qw.

\section{Statistical and Mixing Models}

Methods for development of statistical regression models used to estimate continuous chloride, arsenic, and atrazine concentrations in the Little Arkansas River are described in Christensen and others (2000, 2003). Simple statistical models using streamflow as an explanatory variable were used to estimate daily chloride concentrations from data collected from 1995 through 1998 from the Little Arkansas River and were developed using methods described in Helsel and Hirsch (1992). The use of statistical analysis was necessary to determine estimates of daily chloride concentrations in the stream water for use in the mixing model.

Specific conductance is a good indicator of chloride concentrations in water and was used in a regression equation developed by Christensen and others (2003) to estimate chloride concentrations in water at the Little Arkansas River at Highway 50 near Halstead stream gage. This equation was used to estimate daily chloride concentrations from May 1998 through December 2004 because continuous specific conductance data were available for this time period. The regression equation is:

$$
C l=-33.7+0.209 S C,
$$

where $\mathrm{Cl}$ equals chloride concentration in milligrams per liter $(\mathrm{mg} / \mathrm{L})$ and $S C$ equals specific conductance measurements in microsiemens per centimeter at $25^{\circ} \mathrm{C}$. The coefficient of determination $\left(\mathrm{R}^{2}\right)$ for this regression is 0.96 (Christensen and others, 2003). However, because it was necessary to establish an estimate of daily chloride concentrations in the stream from February 1995 through May 1998, before continuous specific conductance measurements were collected, another regression model was developed for estimating chloride concentrations on the basis of streamflow in the Little Arkansas River at Highway 50 near Halstead. The regression relates measured chloride values to streamflow recorded during sampling (fig. 7). The equation is:

$$
\log _{10} C l=-0.44 \log _{10} Q+2.9
$$

where $C l$ is the estimated chloride concentration in milligrams per liter, and $Q$ is streamflow in cubic feet per second. Equation 3 has an $\mathrm{R}^{2}$ of 0.64 , indicating that specific conductance is a better estimator of chloride concentrations than streamflow. Figure 8 compares continuous chloride concentrations estimated by streamflow (blue line) and continuous chloride concentrations estimated by specific conductance (red line) to measured chloride concentrations in water sampled from the Little Arkansas River at Highway 50 near Halstead (gold line). As expected, figure 8 demonstrates that the regression model developed to estimate chloride concentrations using specific conductance measurements estimated chloride concentrations more accurately than the regression model developed using streamflow. However, when specific conductance measurements were not available, streamflow was determined to be an acceptable alternative with which to estimate chloride concentrations. Continuous specific conductance and streamflow data are available on the Web at http://ks.water.usgs.gov/ Kansas/rtqw/ (accessed December 2006). Chloride concentrations estimated using specific conductance measurements also are available at http://ks.water.usgs.gov/Kansas/rtqw/.

A simple mixing model using estimated chloride concentrations in stream water and measured chloride concentrations in water sampled at the Halstead diversion well site were used to estimate the fraction of stream water pumped from the diversion well. The equation derived from Fischer and others (1979) is:

where

$$
f=\frac{\left(C-C_{a}\right)}{\left(C_{s}-C_{a}\right)},
$$

$f \quad$ is the relative concentration of the chloride in the pumped water $(f=0$ for pure aquifer water and $\mathrm{f}=1$ for pure stream water);

$C$ is the concentration of chloride in the pumped water;

$C_{a} \quad$ is the concentration of chloride in aquifer water; and

$C_{s} \quad$ is the chloride concentration in stream water.

Assumptions associated with the mixing model are related to the variable chloride concentrations in the stream water, which will be discussed further in the section "StreamWater Mixing in Adjacent Aquifer and Solute-Transport Model." 


\section{Flow and Solute-Transport Model}

The program PHAST (Parkhurst and others, 1995; Parkhurst and Kipp, 2002) was used to simulate flow and transport of chloride from the stream through the aquifer into the diversion well. PHAST is a ground-water flow and reactive solute-transport simulator with capabilities to model a wide range of equilibrium and kinetic geochemical reactions (Parkhurst and others, 2004); however, no chemical reactions were included in the simulations described in this report. Flow parameters were calibrated to water-level altitudes measured during aquifer testing. Parameters were estimated using UCODE software (Poeter and Hill, 1998; Poeter and others, 2005). UCODE performs nonlinear regression to estimate parameter values that result in the best fit between simulated values and observations. Estimated parameters included the hydraulic conductivity of the upper and lower sand and gravel aquifer, the hydraulic conductivity of the upper and lower clay layers, and the leakance of the streambed. These parameters were adjusted to accurately simulate the water levels in monitoring wells during the pumping and recovery periods of the aquifer test performed in 1996.

\section{Geochemical Analysis and Simulations}

Geochemical analysis of the effects of artificial recharge was accomplished by two analysis methods. First, an analysis of major ion and trace metal chemistry provided insight into environmental changes that may be occurring as a result of artificial recharge activities. Arsenic and iron are two constituents present in some of the ground water in the artificial recharge system and are sensitive to the $\mathrm{pH}$ and dissolved oxygen concentration in the system. Second, saturation indices were calculated using the computer program PHREEQC (version 2). PHREEQC version 2 is a computer program written in the $\mathrm{C}$ programming language that is designed to perform a wide variety of low-temperature aqueous geochemical calculations including speciation and saturation-index calculations (Parkhurst and Appelo, 1999). Data input in PHREEQC included water temperature, dissolved oxygen concentration, onsite alkalinity, and dissolved concentrations of calcium, magnesium, sodium, potassium, sulfate, chloride, arsenic, iron, and manganese. Measurements of the oxidation-reduction potential (Eh) were used when dissolved oxygen concentrations were less than $0.1 \mathrm{mg} / \mathrm{L}$.

The saturation index $(S I)$ indicates the degree of disequilibrium of a solution with respect to a certain mineral; if a solution is at equilibrium with a given mineral, the mineral will not dissolve or precipitate. The saturation index with respect to a certain mineral (such as calcite, discussed in the following paragraph) can be used to determine the likelihood of a mineral or phase dissolving into or precipitating from a solution. A negative (-) saturation index indicates that the solution is undersaturated with respect to the mineral. If the solution is undersaturated, it has the potential to dissolve the mineral if it is present and kinetics allow. If a saturation index is positive (+), the solution is oversaturated with respect to a mineral, and there is the potential for the mineral to

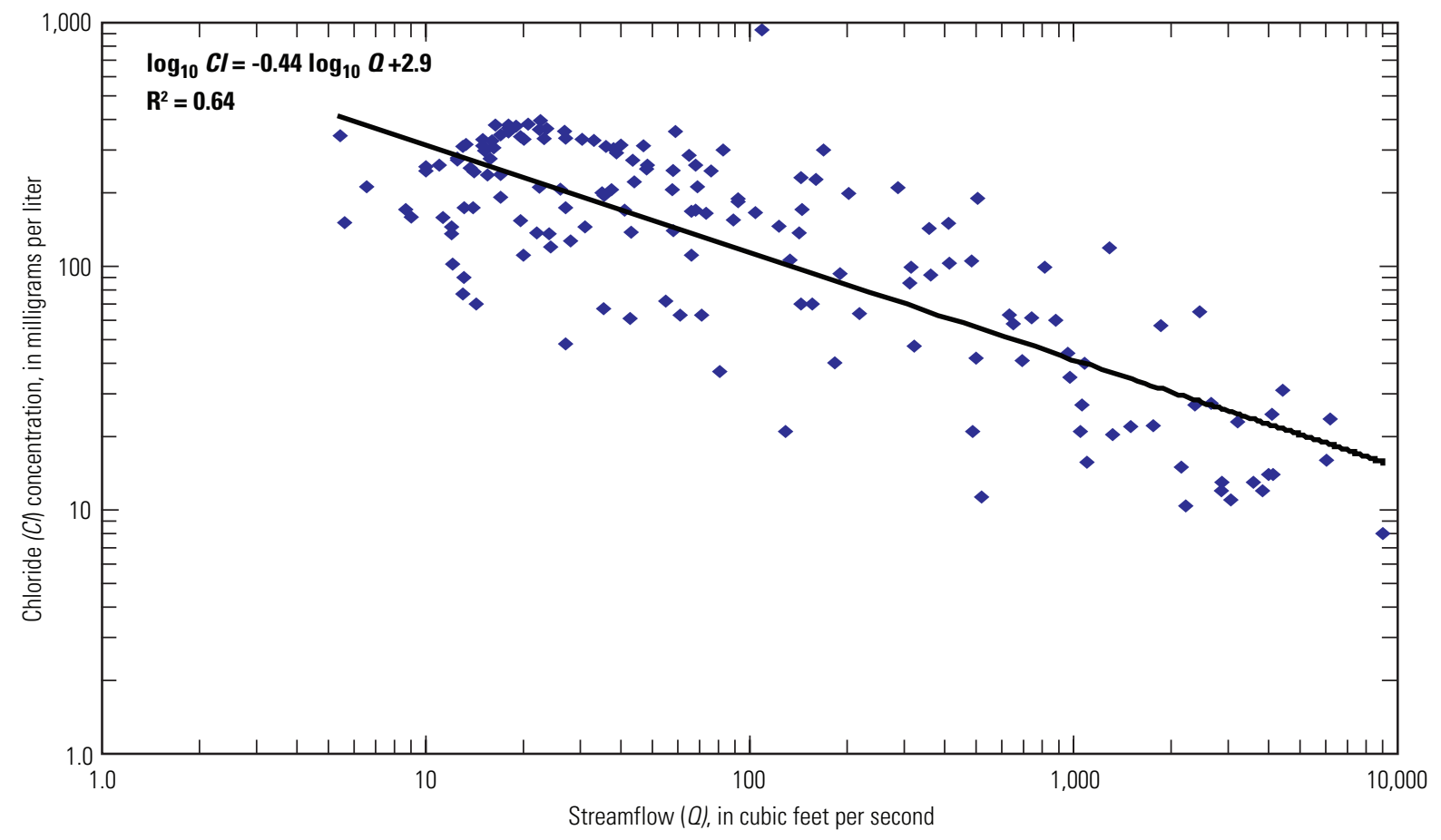

Figure 7. Relation between chloride concentrations and streamflow in Little Arkansas River at Highway 50 near Halstead during demonstration recharge period, April 1996-June 2002. 


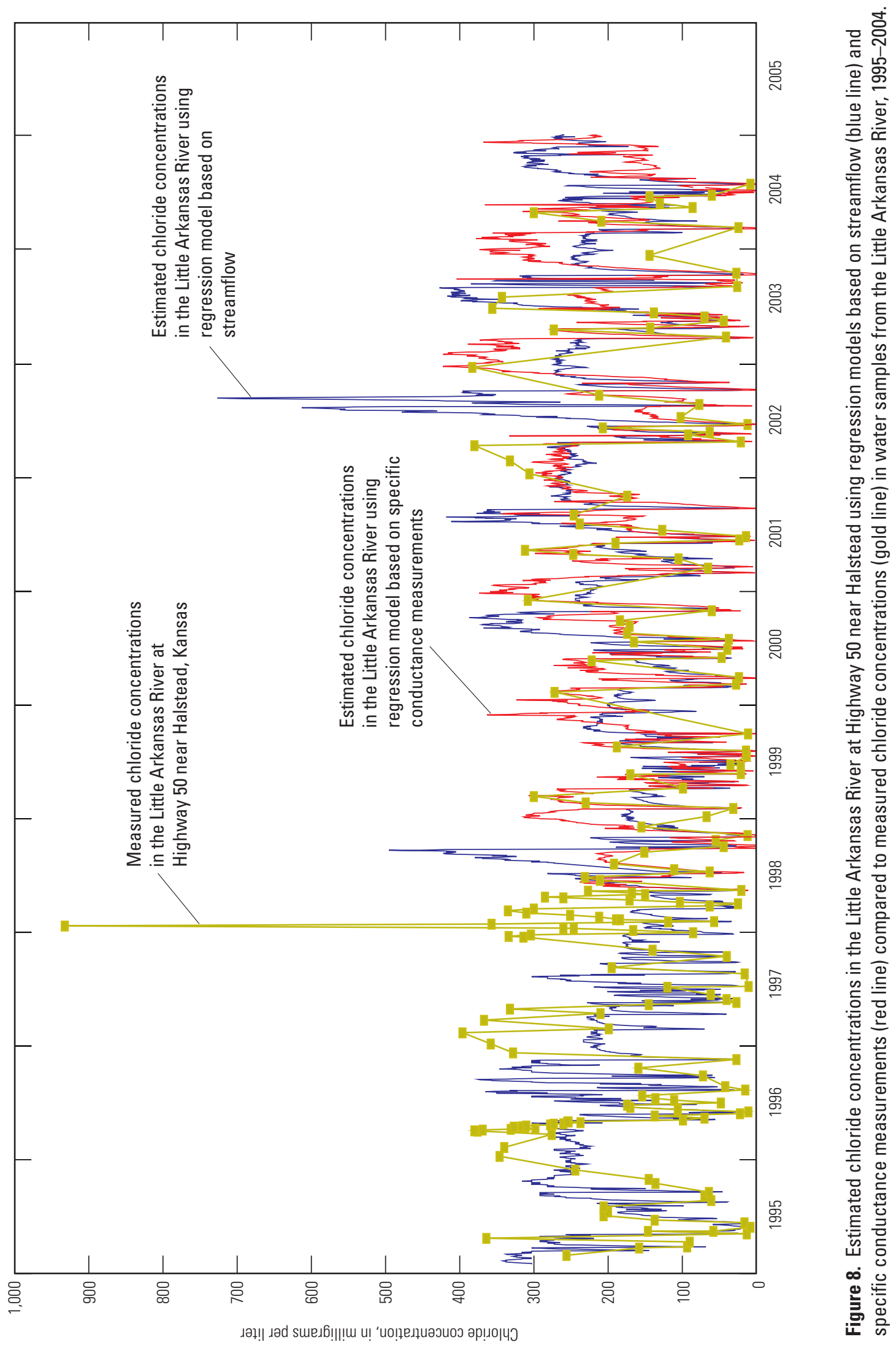


precipitate. A saturation index near 0 indicates that the solution is near equilibrium with the mineral reacting fast enough to maintain equilibrium.

Saturation indices are calculated with respect to certain minerals. The saturation index $(S I)$ is the log of the ion-activity product of a solution divided by the solubility product $\left(K_{\mathrm{sp}}\right)$ (Drever, 1997). For example, the saturation index of calcite $\left(\mathrm{CaCO}_{3}\right)$ is:

$$
\mathrm{SI}=\log \frac{\left[\mathrm{Ca}^{2+}\right]\left[\mathrm{CO}_{3}^{2-}\right]}{K_{\text {sp(calcite) }}}
$$

where $\left[\mathrm{Ca}^{2+}\right]$ is the activity of the calcium ion, $\left[\mathrm{CO}_{3}^{2-}\right]$ is the activity of the carbonate ion, and $K_{\mathrm{sp}}$ is the solubility product of calcite.

The saturation indices for minerals reported herein were identified to be the most important minerals determined by predominant water types. These minerals include carbonate minerals [calcite $\left(\mathrm{CaCO}_{3}\right)$ and dolomite $\left.\left(\mathrm{CaMg}\left(\mathrm{CO}_{3}\right)_{2}\right)\right]$ and iron hydroxides [iron hydroxide (amorphous) $\left(\mathrm{Fe}(\mathrm{OH})_{3}(\mathrm{a})\right]$.

\section{Geochemical Effects of Induced Stream-Water Recharge at the Halstead Diversion Well Site}

A pumping diversion well in the aquifer adjacent to the stream was used to capture water for artificial recharge. Water collected at the Halstead diversion well site was pumped without treatment for recharge at the Halstead recharge site. The pumping diversion well was operated only when streamflow was greater than base-flow conditions described in the previous "Halstead Recharge System" section. Operating a pumping well adjacent to a stream causes a decline in ground-water levels adjacent to the stream, thereby increasing the hydraulic gradient into the adjacent aquifer. The larger hydraulic gradient "induces" stream water to flow into the aquifer toward the pumping well resulting in recharging the adjacent aquifer with stream water. Because all ground-water rights in the area were already fully appropriated, the pumping well was required to induce enough stream water into the adjacent aquifer to replace the water pumped from the well (Jerry Blain, Water Supply Projects Administrator, city of Wichita Water and Sewer Department, written commun., August 2005). The water from the diversion well then was piped $2 \mathrm{mi}$ to the Halstead recharge site for use as recharge water (fig. 1).

Operation of the diversion well will cause a large volume of water to flow to the lower part of the aquifer adjacent to the Little Arkansas River. This flow has the potential for causing changes in $\mathrm{pH}$, water temperature, and dissolved oxygen concentrations, which can have an effect on the solubility and mobility of ions in the aquifer. Mixing two different types of water also can cause precipitation or dissolution of minerals.

\section{Major Ion Chemistry and Tracers of Stream Water}

Piper diagrams (Piper, 1944) were created using calcium, magnesium, sodium, potassium, bicarbonate, sulfate, and chloride concentrations to illustrate major ion chemistry in water sampled from the Little Arkansas River, monitoring wells, and the diversion well at the Halstead diversion well site (fig. 9A-D). A Piper diagram is a way to classify water on the basis of relative proportions of the major ions in the water sample (Drever, 1997). Piper diagrams were constructed with water samples from March 1996 (fig. 9A), representing pre-pumping conditions; July1996 (fig. 9B), representing post aquifer-test conditions; June 2001 (fig. 9C), representing conditions after approximately $700 \mathrm{Mgal}$ of water had been pumped from the diversion well; and May 2003 (fig. 9D), representing conditions after the end of the demonstration project. The dominant cation percentage of water sampled from all monitoring wells and the diversion well at the diversion well site ranged from no dominant type to calcium bicarbonate type water. The dominant anion was bicarbonate for water sampled from the monitoring wells and diversion well at the site. Water types for all monitoring wells trended toward the calcium bicarbonate fields for samples collected during and after artificial recharge activities.

Chloride and the triazine herbicide, atrazine, generally occurred in larger concentrations in stream water than in ground water not affected by stream chemistry at the Halstead diversion well site. The source of dissolved chloride concentrations in the Little Arkansas River may be related to past oil and gas activities near McPherson and Burrton or wastewater-treatment and industrial discharges from McPherson and Newton (Donald Whittemore, Kansas Geological Survey, oral commun., 1999). USEPA has established a Secondary Drinking-Water Regulation (SDWR) of $250 \mathrm{mg} / \mathrm{L}$ for chloride concentrations in drinking water (U.S. Environmental Protection Agency, 2004). Chloride is a conservative constituent and does not degrade chemically or readily react with other constituents as it moves through the hydrologic system (Hem, 1992). The difference between the chloride concentrations in the ground water and stream water at the diversion well site were distinct enough to use chloride as a natural tracer of stream water into the adjacent aquifer.

Chloride concentrations generally were larger in shallow monitoring wells EB-145-A1, EB-145-A2, and EB-145-A3, which are less than $500 \mathrm{ft}$ from the Little Arkansas River and, therefore, are more affected by the stream-water chemistry (fig. $10 A-B$ ) than in shallow monitoring wells EB-145-A4 and EB-145-A5. The shallow monitoring wells also are screened above the clay layer. Measured chloride concentrations in water sampled from the Little Arkansas River at Highway 50 near Halstead ranged from 5 to $930 \mathrm{mg} / \mathrm{L}$ with a median concentration of $153 \mathrm{mg} / \mathrm{L}$ (fig. 10A). Continuous chloride concentrations estimated from measured specific conductance values were available from 1999 through 2004 for the Little Arkansas River at Highway 50 near Halstead 
(data available on the Web at http://ks.water.usgs.gov/Kansas/ $r t q w /$, accessed December 2006). Estimated chloride concentrations ranged from less than 5 to $445 \mathrm{mg} / \mathrm{L}$ with a median concentration of $193 \mathrm{mg} / \mathrm{L}$. Estimated chloride concentrations exceeded the SDWR of $250 \mathrm{mg} / \mathrm{L} 30$ percent of the time during the 6-year period. Chloride concentrations in water samples from shallow monitoring well EB-145-A1, located closest to the stream, were variable and ranged from 80 to $275 \mathrm{mg} / \mathrm{L}$ with a median concentration of $159 \mathrm{mg} / \mathrm{L}$ (fig. 10B). Chloride concentrations in water samples from well EB-145-A1 exceeded the SDWR in 5 of 61 samples collected from 1995 through 2004. Chloride concentrations in water samples from monitoring wells EB-145-A2 and EB-145-A3 were less variable than in samples from well EB-145-A1 and ranged from 139 to $203 \mathrm{mg} / \mathrm{L}$ with a median concentration of $164 \mathrm{mg} / \mathrm{L}$ and 88 to $178 \mathrm{mg} / \mathrm{L}$ with a median concentration of $146 \mathrm{mg} / \mathrm{L}$, respectively (fig. 10B). Monitoring wells EB-145-A4 and EB-145-A5 were not affected by the stream-water chemistry and had small median chloride concentrations of 19 and $32 \mathrm{mg} / \mathrm{L}$, respectively (fig. 10C), which are considered background concentrations in this part of the aquifer.

Chloride concentrations were about $15 \mathrm{mg} / \mathrm{L}$ in water samples from deep monitoring well EB-145-PD5 prior to recharge activities beginning at the site (fig. 10C). Pumping at the site, which began with an aquifer test in April 1996,

\section{(A) March 1996}

\section{EXPLANATION}

A Monitoring well EB-145-A1

$\checkmark$ Monitoring well EB-145-A2

O Monitoring well EB-145-PD5

- Diversion well

$\star$ Little Arkansas River at Highway 50 near Halstead

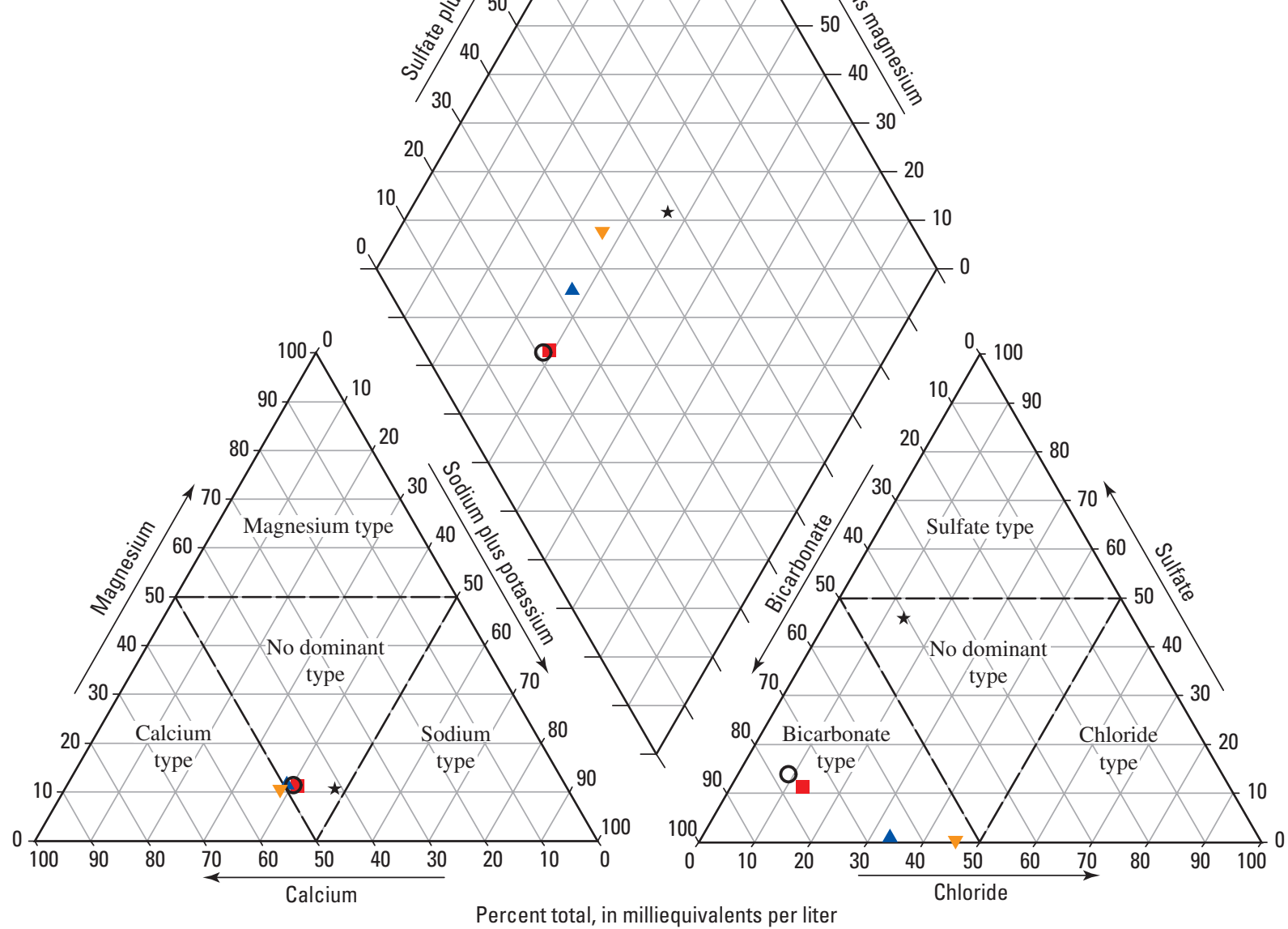

Figure 9. Major ion chemistry of water samples from monitoring wells and diversion well at the Halstead diversion well site during (A) March 1996, (B) July 1996, (C) June 2001, and (D) May 2003. 
caused an increase in chloride concentrations in water sampled from well EB-145-PD5 as ground water affected by streamwater chemistry flowed into the deeper part of the aquifer. At the conclusion of the aquifer test in July 1996, the chloride concentrations in water samples from well EB-145-PD5 had increased from a background concentration of approximately 15 to approximately $30 \mathrm{mg} / \mathrm{L}$. When pumping resumed in May 1997 and continued intermittently until May 2002, the end of the demonstration project, chloride concentrations increased to a maximum concentration of about $130 \mathrm{mg} / \mathrm{L}$ in March 2002. Chloride concentrations in water sampled from well EB-145-PD5 steadily decreased to a concentration of about $40 \mathrm{mg} / \mathrm{L}$ after artificial recharge activities ended (fig. 10B).
Chloride concentrations in water samples from the diversion well, the recharge water used at the Halstead recharge site, were initially about $20 \mathrm{mg} / \mathrm{L}$ but steadily increased to about $55 \mathrm{mg} / \mathrm{L}$ near the end of the aquifer test in July 1996 (fig. 10C). When the pumping for the demonstration project resumed, chloride concentrations in water samples from the diversion well reached a stable median concentration of about 60 mg/L from May 1997 through June 2002.

Specific conductance in recharge water collected from the diversion well can be monitored on a real-time basis and provides a reliable estimate of chloride concentrations. Therefore, artificial recharge practices could be altered if estimated chloride concentrations in recharge water exceeded the SDWR of

\section{(B) July 1996}

\section{EXPLANATION}

• Monitoring well EB-145-A1

$\checkmark$ Monitoring well EB-145-A2

+ Monitoring well EB-145-A3

$\times$ Monitoring well EB-145-A4

- Monitoring well EB-145-A5

O Monitoring well EB-145-PD5

- Diversion well

$\star$ Little Arkansas River at

Highway 50 near Halstead
100

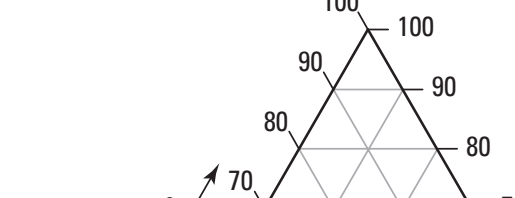

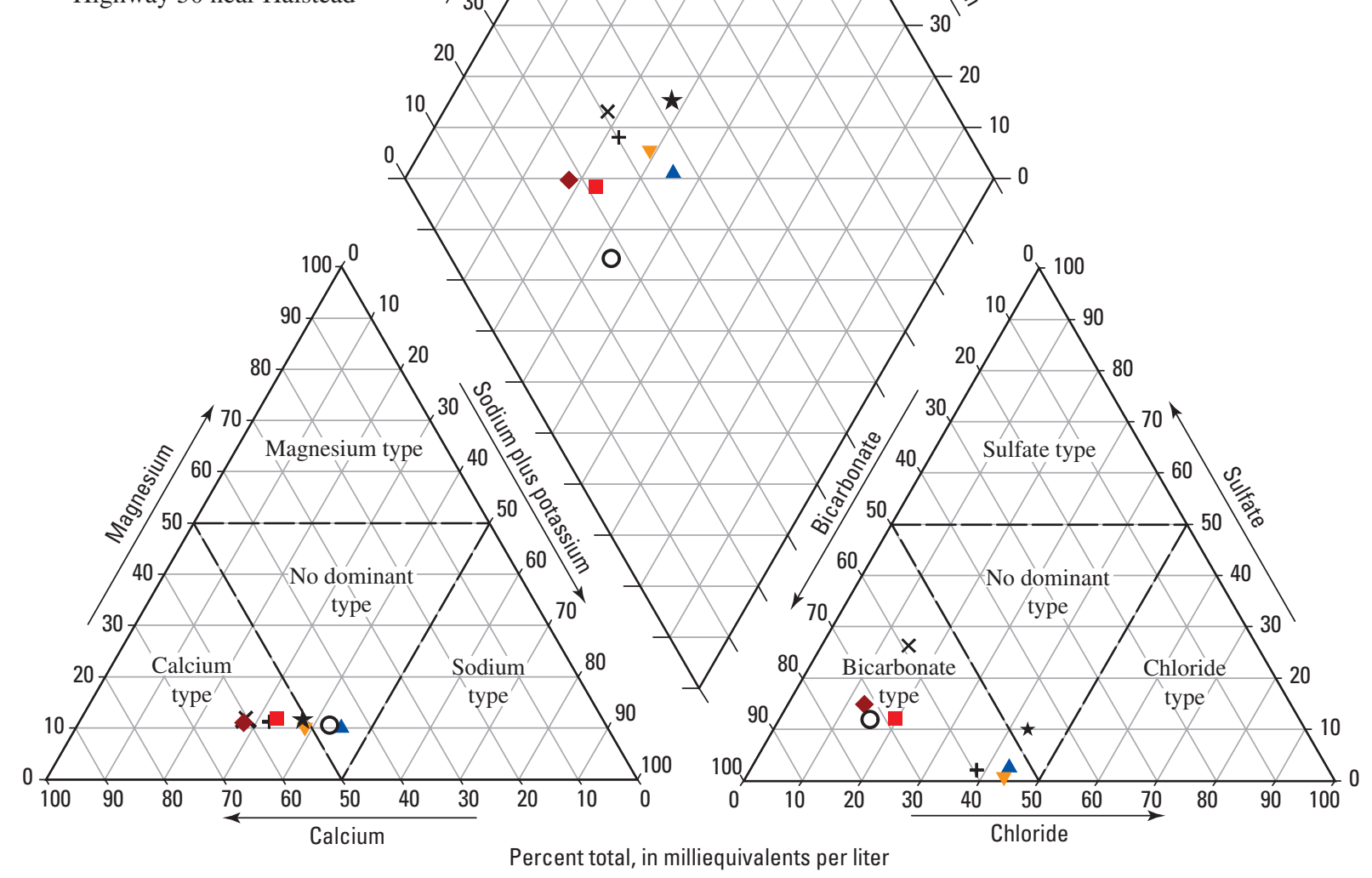

Figure 9. Major ion chemistry of water samples from monitoring wells and diversion well at the Halstead diversion well site during (A) March 1996, (B) July 1996, (C) June 2001, and (D) May 2003-Continued. 
$250 \mathrm{mg} / \mathrm{L}$, which would help prevent degradation of the Equus Beds aquifer by chloride. A regression model was developed for future monitoring which relates specific conductance measurements to chloride concentrations in the water sampled from the diversion well (fig. 11). The model equation is:

$$
C l=-45.8+0.131 S C,
$$

where $\mathrm{Cl}$ is chloride concentration in milligrams per liter and $S C$ is specific conductance in microsiemens per centimeter at $25^{\circ} \mathrm{C}$. The regression has an $\mathrm{R}^{2}$ of 0.86 .

Atrazine is a broadleaf, pre-emergent herbicide that is used for weed control in corn and grain sorghum. Atrazine commonly is applied to crops in the study area and is detected frequently in the Little Arkansas River, especially during the growing season (April-September). Atrazine has an MCL of $3.0 \mu \mathrm{g} / \mathrm{L}$ as an annual average (U.S. Environmental Protection Agency, 2004). Atrazine degrades chemically in the environment and does not occur naturally. Therefore, the presence of atrazine in the pumped diversion well water indicates movement of stream-affected ground water towards the deep pumping well. In addition to chloride, the presence of atrazine concentrations was used as evidence of the movement of shallow ground water into the deeper part of the aquifer.

Atrazine concentrations in discrete water-quality samples collected from the Little Arkansas River at Highway 50 ranged from less than 0.10 to $47 \mu \mathrm{g} / \mathrm{L}$ (fig. $12 A$ ). Continuous atrazine

\section{(C) June 2001}

\section{EXPLANATION}

A Monitoring well EB-145-A1

$\checkmark$ Monitoring well EB-145-A2

+ Monitoring well EB-145-A3

$\times$ Monitoring well EB-145-A4

$\checkmark$ Monitoring well EB-145-A5

O Monitoring well EB-145-PD5

- Diversion well

$\star$ Little Arkansas River at

Highway 50 near Halstead

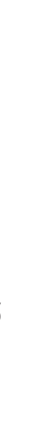

100

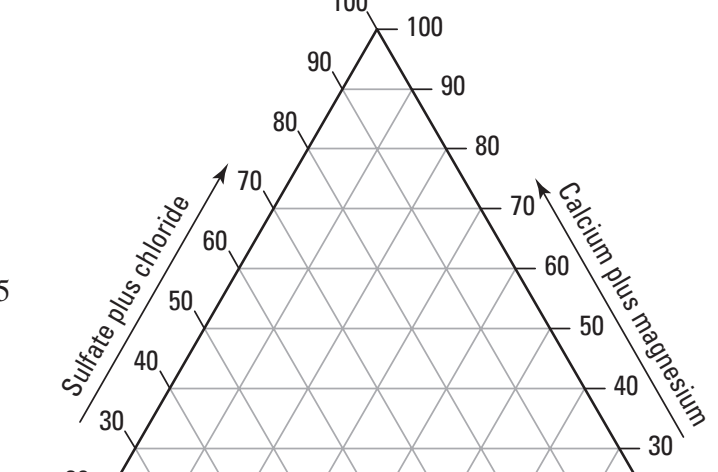

0

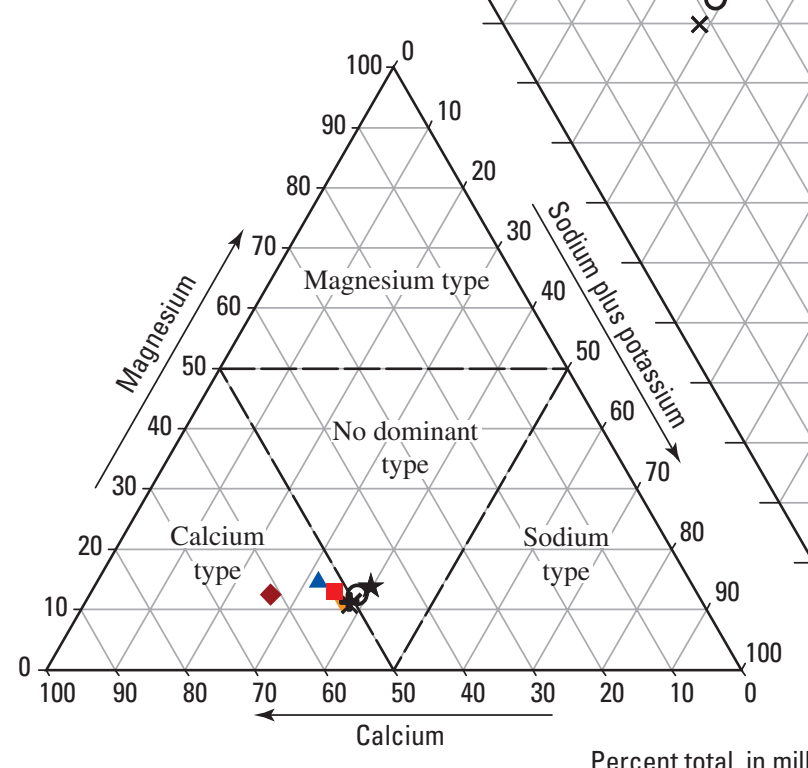

Percent total, in milliequivalents per liter

Figure 9. Major ion chemistry of water samples from monitoring wells and diversion well at the Halstead diversion well site during (A) March 1996, (B) July 1996, (C) June 2001, and (D) May 2003-Continued. 
concentrations were estimated by the regression model:

$$
\begin{gathered}
\log _{10} \text { atrazine }=0.430-0.643 \cos \left(\frac{2 \pi D}{365}\right)+ \\
0.359 \sin \left(\frac{2 \pi D}{365}\right)-0.00079 S C,
\end{gathered}
$$

where atrazine is in micrograms per liter, $D$ equals the julian day of year, and $S C$ equals specific conductance measurements in microsiemens per centimeter at $25^{\circ} \mathrm{C}$ (Christensen and others, 2000, 2003). Continuous data are available on the Web at http://ks.water.usgs.gov/Kansas/rtqw/ (accessed December 2006).

Annual averages calculated from daily estimates of atrazine were equal to the MCL of $3.0 \mu \mathrm{g} / \mathrm{L}$ in 1999 and smaller than $3.0 \mu \mathrm{g} / \mathrm{L}$ from 2000 through 2004. Average rather than median concentrations of atrazine are discussed in this report to facilitate a direct comparison of measured and estimated atrazine concentrations to the MCL, which is defined as an annual average. Atrazine concentrations in water samples from shallow monitoring wells EB-145-A1, EB-145-A2, and EB-145-A3 were the largest when compared to all samples from the monitoring wells at the diversion well site, and concentrations fluctuated from less than 0.10 to about $2.6 \mu \mathrm{g} / \mathrm{L}$ (fig. 12B). Atrazine was not detected in water from shallow monitoring wells EB-145-A4 and EB-145-A5.

Atrazine concentrations in water samples from deep monitoring well EB-145-PD5 were less than or equal to 0.10 $\mu \mathrm{g} / \mathrm{L}$ from October 1995 through May 1996 (fig. 12C). Detec-

\section{(D) May 2003}

\section{EXPLANATION}

A Monitoring well EB-145-A1

$\nabla$ Monitoring well EB-145-A2

+ Monitoring well EB-145-A3

$\times$ Monitoring well EB-145-A4

- Monitoring well EB-145-A5

O Monitoring well EB-145-PD5

$\star$ Little Arkansas River at Highway 50 near Halstead

5

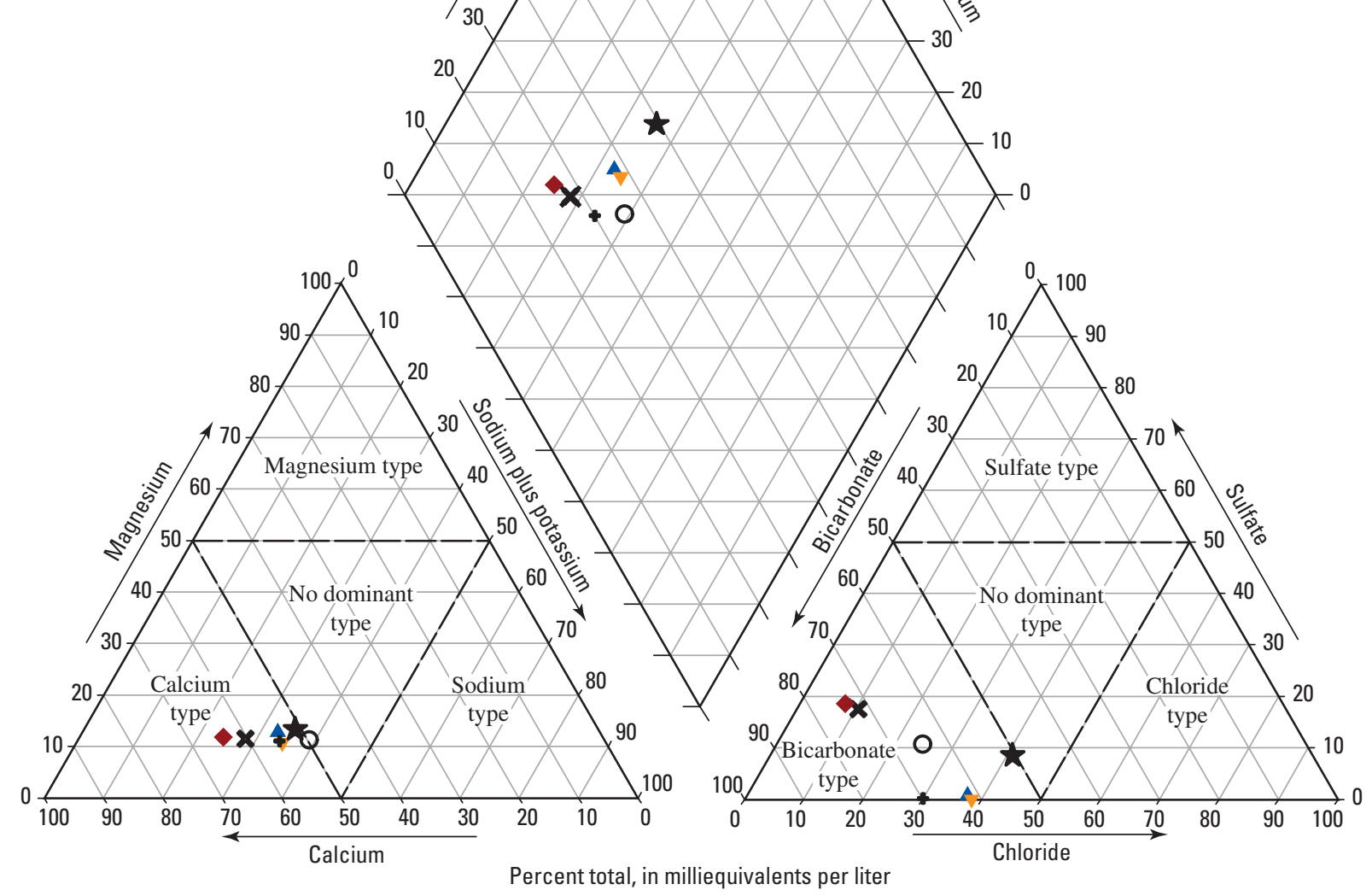

Figure 9. Major ion chemistry of water samples from monitoring wells and diversion well at the Halstead diversion well site during (A) March 1996, (B) July 1996, (C) June 2001, and (D) May 2003-Continued. 

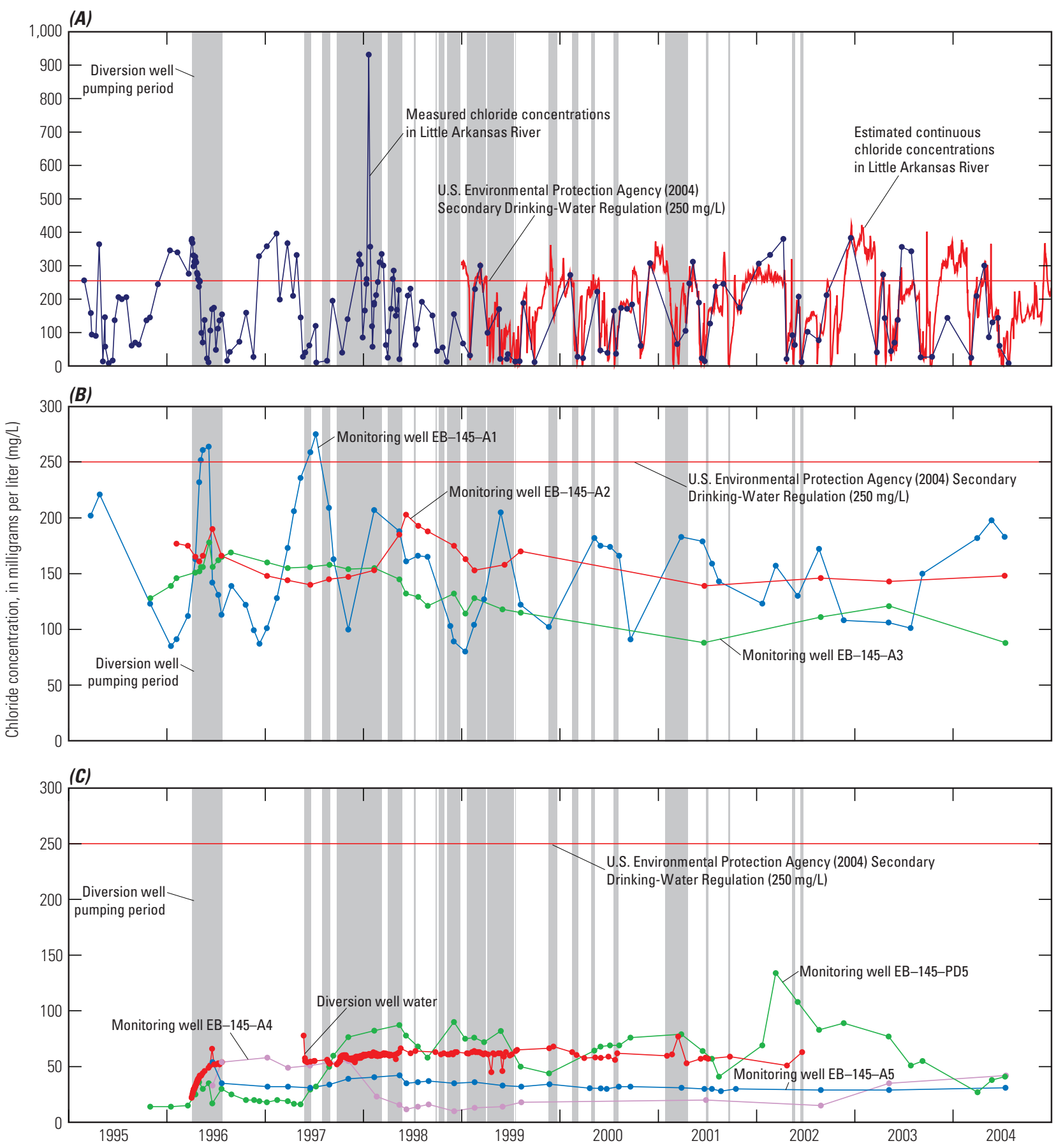

Figure 10. Measured and estimated chloride concentrations in water samples from (A) Little Arkansas River at Highway 50 near Halstead (site 07143672, fig. 1), (B) shallow monitoring wells EB-145-A1, EB-145-A2, and EB-145-A3, and (C) shallow monitoring wells EB-145-A4 and EB-145-A5, deep monitoring well EB-145-PD5, and diversion well water at Halstead diversion well site, February 1995-December 2004.

tions of atrazine larger than $0.10 \mu \mathrm{g} / \mathrm{L}$ increased after September 1997 with the largest concentration of $0.33 \mu \mathrm{g} / \mathrm{L}$ occurring in December 1998. The increase in atrazine concentrations in water from well EB-145-PD5 corresponded with the increase in chloride concentrations and indicates the presence of ground water from the upper part of the adjacent aquifer flowing to the lower part of the aquifer. Pumping of ground water at the Halstead diversion well site has caused increased chloride concentrations from 15 to $130 \mathrm{mg} / \mathrm{L}$ and increased atrazine concentrations from less than 0.10 to $0.33 \mu \mathrm{g} / \mathrm{L}$ in deep monitoring well EB-145-PD5. 


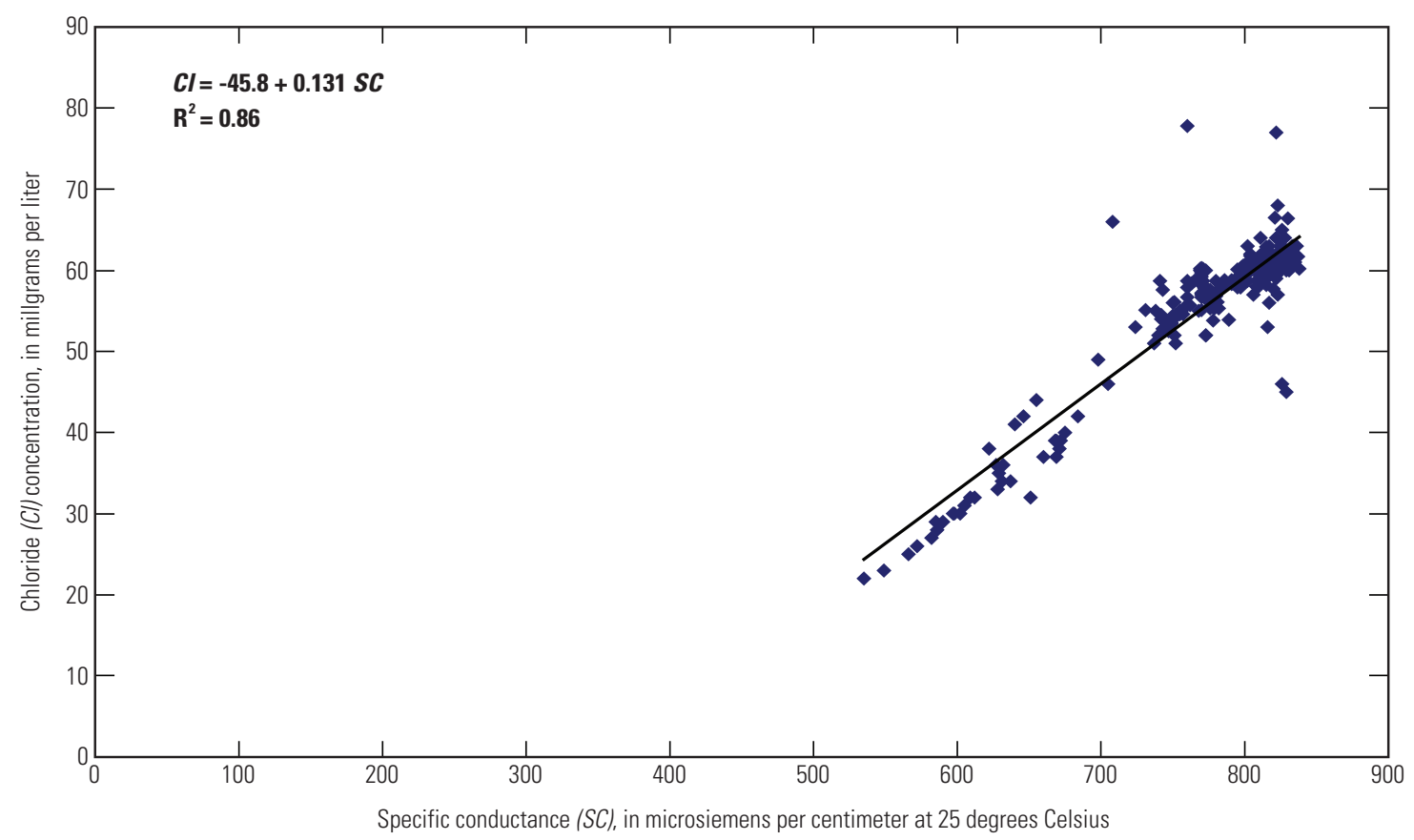

Figure 11. Relation between chloride concentrations and specific conductance measurements in water from diversion well at Halstead diversion well site, February 1995-May 2002.

Atrazine was detected in 48 of 282 (17 percent) water samples from the diversion well. Atrazine initially was detected about 4 months after pumping began at the site and was detected periodically throughout the remainder of the demonstration project with the largest detection of $0.42 \mu \mathrm{g} / \mathrm{L}$ occurring in June 2000.

Deethylatrazine and deisopropylatrazine are degradation products of atrazine (table 2). Deethylatrazine concentrations in water sampled from the Little Arkansas River ranged from less than 0.05 to $1.8 \mu \mathrm{g} / \mathrm{L}$ (table 2). The largest detection of deethylatrazine was $0.17 \mu \mathrm{g} / \mathrm{L}$ in water from well EB-145-A1 and $0.08 \mu \mathrm{g} / \mathrm{L}$ in water from well EB-145-A2 (table 2). Concentrations of deisopropylatrazine ranged from less than 0.05 to $1.2 \mu \mathrm{g} / \mathrm{L}$ in stream water. There were two detections in 32 samples analyzed for deisopropylatrazine in the water samples from monitoring well EB-145-A1 at the Halstead diversion well site. Deisopropylatrazine was not detected in water from any other monitoring well or in water sampled from the diversion well at the site. Detections of atrazine degradation products were rare, which indicates decreases in atrazine concentration are more likely because of adsorption by aquifer material than because of degradation.

\section{Selected Trace Metal Chemistry}

The influx of stream water caused by operation of the pumping well could affect the mobility of dissolved arsenic at the diversion well site. Also, induced stream-water recharge could stimulate growth of iron bacteria and cause precipita- tion of iron minerals from ground water. If arsenic is dissolved from the aquifer material, it could increase the dissolved arsenic concentration in the local ground water; dissolved arsenic has an MCL of $10 \mu \mathrm{g} / \mathrm{L}$ in drinking water established by USEPA (U.S. Environmental Protection Agency, 2004).

Arsenic is a trace element that occurs naturally in the environment; however, large concentrations of arsenic have been shown to be detrimental to human health (Hem, 1992). In 2004, USEPA revised the arsenic drinking-water criterion for arsenic from 50 to $10 \mu \mathrm{g} / \mathrm{L}$. The new criterion became effective on January 23, 2006 (U.S. Environmental Protection Agency, 2004). Adsorption or coprecipitation by iron oxyhydroxide and association with sulfide in reduced bottom mud appear to be major inorganic factors that can maintain arsenic at very small concentrations in water (Hem, 1992). Arsenic is considered to be naturally occurring in clay layers in the Equus Beds aquifer.

The mobility of arsenic in the hydrologic environment generally is controlled by two categories of processesadsorption and desorption reactions and solid-phase precipitation and dissolution reactions (Hinkle and Polette, 1999). These processes are affected by $\mathrm{pH}$, redox reactions, and the presence of competing anions in the water, all of which could be altered as a result of artificial recharge activities. The adsorption of arsenic to iron-oxide surfaces tends to decrease as $\mathrm{pH}$ increases; therefore, changes in ground-water $\mathrm{pH}$ can promote adsorption or desorption of arsenic. The redox state in which arsenic occurs has an important effect on the mobility of arsenic. Arsenate (As V) is dominant under oxidizing con- 


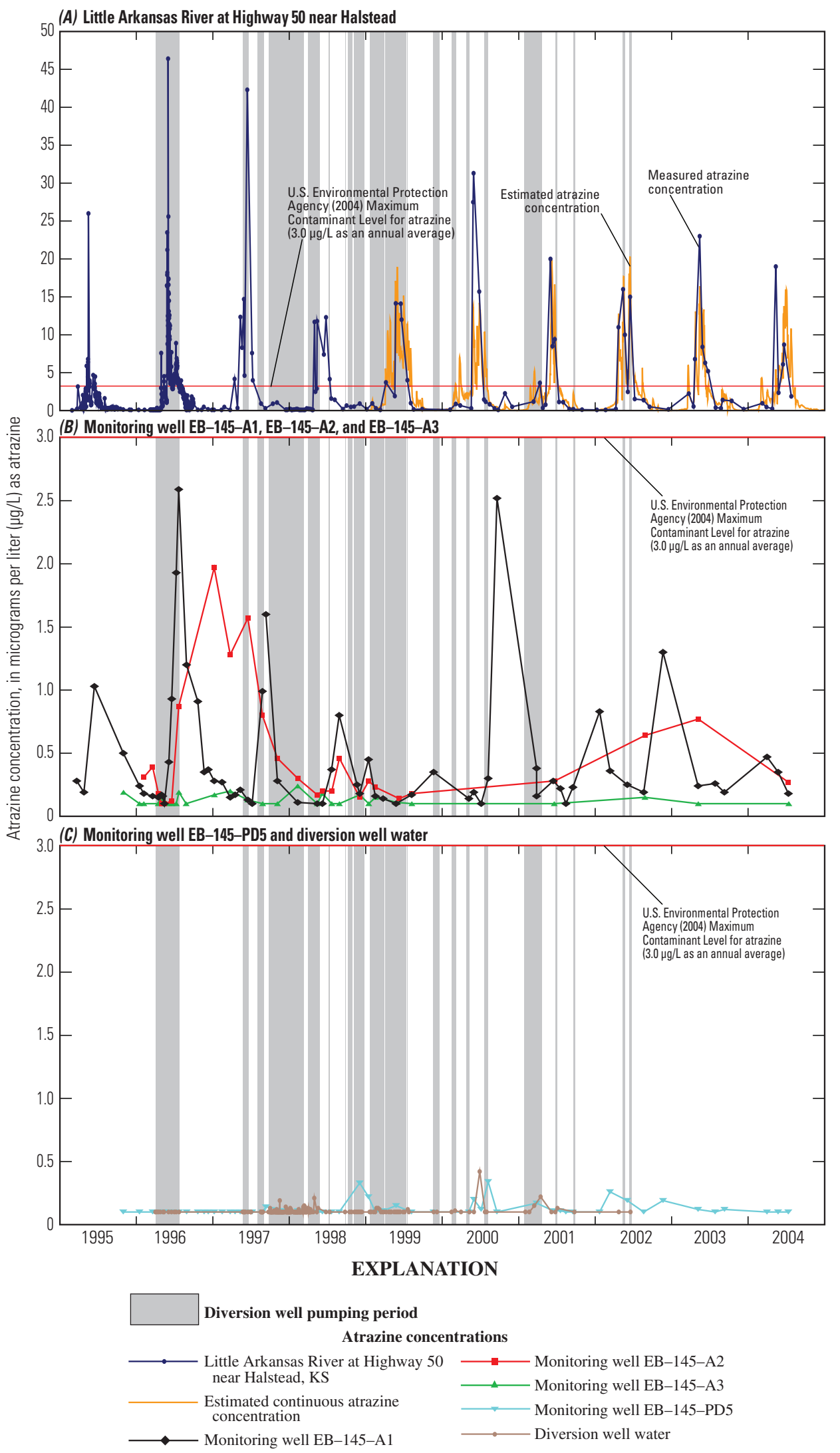

Figure 12. Measured and estimated atrazine concentrations $(A)$ in water from Little Arkansas River at Highway 50 near Halstead (station 07143672, fig. 1) and from (B) shallow monitoring wells EB-145-A1, EB-145-A2, and EB-145-A3, (C) deep monitoring well EB-145-PD5, and diversion well water at Halstead diversion well site, February 1995-December 2004. 
Table 2. Results of analysis of atrazine degradation products in water samples from the Little Arkansas River, from monitoring wells, and the diversion well at the Halstead diversion well site, south-central Kansas, 1995-2004.

$[\mu \mathrm{g} / \mathrm{L}$, micrograms per liter; <, less than; ND, not detected]

\begin{tabular}{|c|c|c|c|c|c|c|}
\hline \multirow[b]{2}{*}{ Sampling site (fig. 2) } & \multicolumn{3}{|c|}{ Deethylatrazine } & \multicolumn{3}{|c|}{ Deisopropylatrazine } \\
\hline & $\begin{array}{l}\text { Number of } \\
\text { samples }\end{array}$ & $\begin{array}{l}\text { Number of } \\
\text { detections }\end{array}$ & $\begin{array}{c}\text { Range in } \\
\text { concentration } \\
(\mu \mathrm{g} / \mathrm{L})\end{array}$ & $\begin{array}{l}\text { Number of } \\
\text { samples }\end{array}$ & $\begin{array}{l}\text { Number of } \\
\text { detections }\end{array}$ & $\begin{array}{c}\text { Range in } \\
\text { concentration } \\
(\mu \mathrm{g} / \mathrm{L})\end{array}$ \\
\hline $\begin{array}{l}\text { Little Arkansas River at Highway } 50 \text { near } \\
\text { Halstead }\end{array}$ & 77 & 43 & $<0.05-1.8$ & 47 & 35 & $<0.05-1.2$ \\
\hline Shallow monitoring well EB-145-A3 & 19 & 0 & ND & 15 & 0 & ND \\
\hline Shallow monitoring well EB-145-A4 & 10 & 0 & ND & 7 & 0 & ND \\
\hline Shallow monitoring well EB-145-A5 & 14 & 0 & ND & 11 & 0 & ND \\
\hline
\end{tabular}

ditions, and arsenite (As III) is dominant under more reducing conditions.

Arsenic concentrations in 13 percent of the 54 discrete water-quality samples from the Little Arkansas River at Highway 50 near Halstead exceeded the MCL of $10 \mu \mathrm{g} / \mathrm{L}$ (fig. 13A). Arsenic speciation data were collected for selected samples from March 2003 through July 2004. Arsenate $\left(\mathrm{AsO}_{4}^{-3}\right)$ was the dominant arsenic species in samples collected from the Little Arkansas River at Highway 50 near Halstead, which is typical of oxygenated water. Continuous arsenic concentrations were estimated by the regression model:

$$
\log _{10} \text { arsenic }=1.16-0.227 \log _{10} Q,
$$

where arsenic is in micrograms per liter and $Q$ is streamflow in cubic feet per second from the Little Arkansas River at Highway 50 near Halstead. The regression $\mathrm{R}^{2}$ is 0.66 (Christensen and others, 2003). Data are available on the Web at http://ks.water.usgs.gov/Kansas/rtqw/ (accessed December 2006). Estimated arsenic concentrations exceeded the MCL 10 percent of the days from 1999 through 2004. Larger arsenic concentrations in stream water generally occurred during times of low streamflow when base flow to the stream is supplied from the ground water.

Initial water samples from well EB-145-A1 had arsenic concentrations of 10 and $5 \mu \mathrm{g} / \mathrm{L}$, but arsenic was not detected in the remainder of the water samples from this well. Arsenic concentrations in samples from shallow monitoring wells EB-145-A2 and EB-145-A3 were slightly larger than the detection limit and did not vary substantially throughout the study period indicating that the induced stream-water recharge at this site did not transport dissolved arsenic or mobilize sorbed arsenic near this well.
Arsenic concentrations consistently were larger than the MCL in water from shallow monitoring wells EB-145-A4 and EB-145-A5 (fig. 13B). Median arsenic concentrations were 16 and $25 \mu \mathrm{g} / \mathrm{L}$ in water samples from wells EB-145-A4 and EB-145-A5, respectively. Arsenite (As III), the dominant species in more reducing conditions, was the dominant arsenic species in these two wells. Stream water does not appear to migrate as far as wells EB-145-A4 and A5 as demonstrated by chloride and atrazine concentrations; therefore, it is not expected that arsenic concentrations in water sampled from these two wells would be affected by diversion activities.

The median arsenic concentration calculated from water sampled from deep monitoring well EB-145-PD5 was $22 \mu \mathrm{g} / \mathrm{L}$ throughout the entire study period. However, there was a substantial increase in concentrations from March 2001 through July 2003 after the majority of pumping of the diversion well ended. Arsenic concentrations in water samples from well EB-145-PD5 reached a maximum concentration of $49 \mu \mathrm{g} / \mathrm{L}$ in July 2003 and steadily decreased to concentrations of about $37 \mu \mathrm{g} / \mathrm{L}$ through July 2004 . The arsenic peak in July 2003 followed peak concentrations in iron and manganese in November 2002 (fig. 14). Guo and others (1997) found that arsenic was released after iron and manganese had dissolved during experiments where spiked sediment columns were progressively reduced, suggesting that dissolution rather than desorption was the dominant process (Smedley and Kinniburgh, 2002). The increase in iron and manganese concentrations followed by the increase in arsenic at this site indicates the local area became more reducing temporarily and caused dissolution of arsenic from aquifer material. The increase in arsenic concentrations also corresponded to the lowest naturally occurring (not caused by pumping of diverion well) water levels recorded at the site. Arsenic speciation data collected 

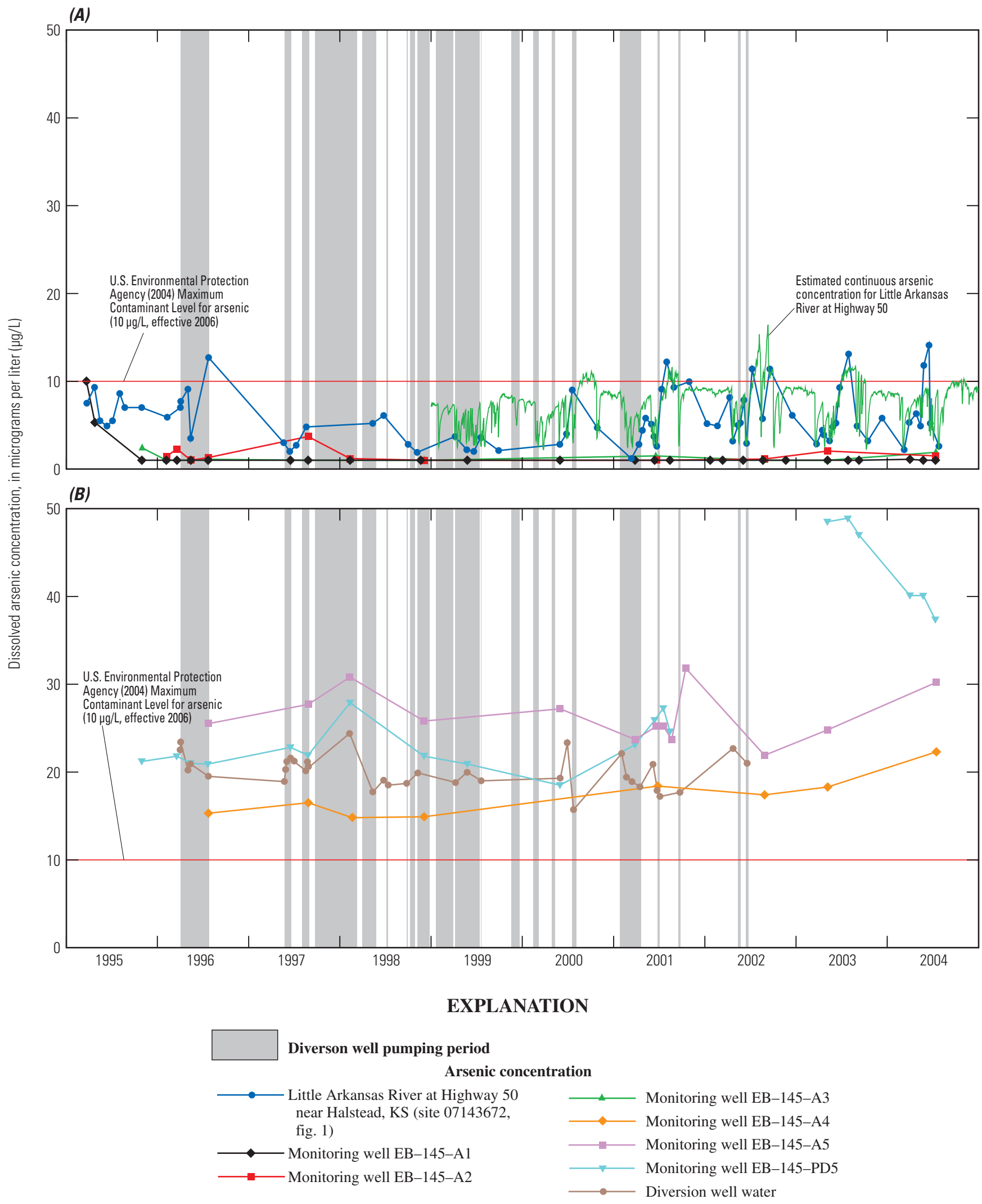

Figure 13. Measured and estimated arsenic concentrations in $(A)$ water samples from Little Arkansas River at Highway 50 near Halstead and from shallow monitoring wells EB-145-A1, EB-145-A2, and EB-145-A3 and (B) shallow monitoring wells EB-145-A4, EB-145-A5, deep monitoring well EB-145-PD5, and diverted recharge water at Halstead diversion well site, February 1995-December 2004. Location of wells shown in figure $2 A$. 


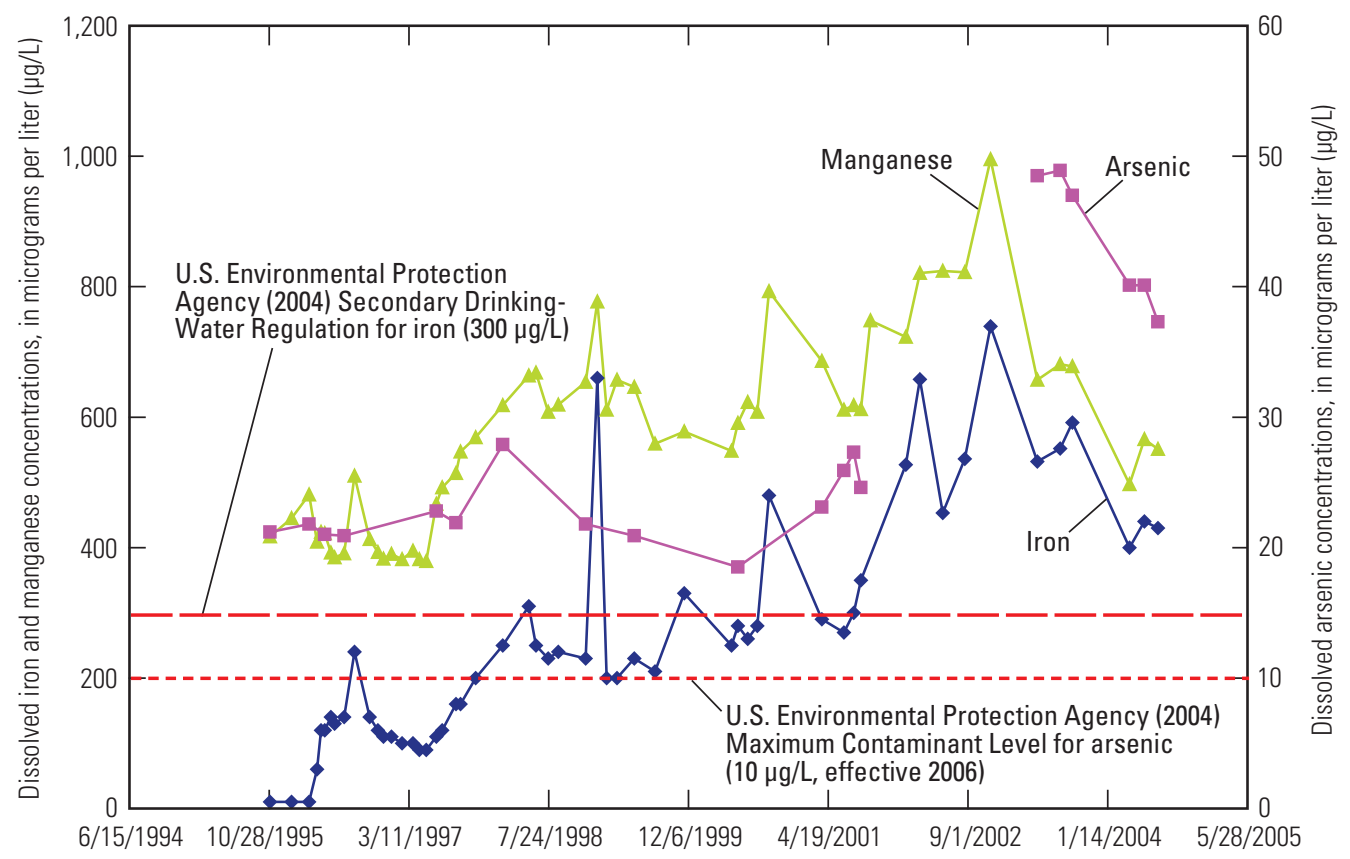

Figure 14. Arsenic, iron, and manganese concentrations, in deep monitoring well EB-145-PD5 at Halstead diversion well site, February 1995-December 2004.

from May 2003 through July 2004 indicate arsenite (As III) is the dominant species in monitoring well EB-145-PD5, which is the dominant species under more reducing conditions.

Water sampled from the diversion well had a median arsenic concentration of $20 \mu \mathrm{g} / \mathrm{L}$, and arsenic concentrations did not change substantially during pumping. Arsenic concentrations in water from the diversion well were consistent with concentrations in water from shallow monitoring wells EB-145-A4 and EB-145-A5 and in water from well EB-145-PD5 prior to March 2001.

Iron concentrations also are affected by the $\mathrm{pH}$ and dissolved oxygen concentrations of a hydrologic system. Iron is a trace metal that generally occurs in small concentrations in water. The chemical reactions of iron and its solubility in water depend largely on the degree of oxidation and the bacterial activity in the hydrologic system (Hem, 1992). USEPA established a SDWR of $300 \mu \mathrm{g} / \mathrm{L}$ for iron in finished drinking water because iron can cause taste-and-odor problems, corrosion of pipes, deposits of scale or sediment, and staining of laundry (U.S. Environmental Protection Agency, 2004). Iron bacteria can have an effect on dissolved iron concentrations in an aquifer and can be of particular concern in artificial recharge operations. The addition of oxygenated water to a system could create favorable conditions for increased bacterial activity. In turn, increased biological activity can produce a biofilm that can clog well screens and reduce the efficiency of injection wells. Bacterial activity may increase or decrease dissolved iron concentrations in water intercepted by wells (Hem, 1992).

Dissolved iron concentrations observed in the Little Arkansas River, monitoring wells, and the diversion well at the
Halstead diversion well site varied from less than 5 to $6,250 \mu \mathrm{g} / \mathrm{L}$ (fig. $15 A-B$ ). The largest and most variable concentrations of iron occurred in water samples from shallow monitoring well EB-145-A1, which is closest to the stream. Iron concentrations in water from this well ranged from 1,600 to $6,250 \mu \mathrm{g} / \mathrm{L}$. Iron concentrations increased in water samples from well EB-145-A1 beginning in July 2003 after the end of diversion well pumping. Samples from monitoring well EB145-A2 also had relatively large iron concentrations, ranging from 1,600 to $2,700 \mu \mathrm{g} / \mathrm{L}$. The iron concentrations in shallow monitoring wells EB-145-A3, EB-145-A4, and EB-145-A5 increased in response to pumping from less than or equal to $300 \mu \mathrm{g} / \mathrm{L}$ to between 300 and 1,000 $\mu \mathrm{g} / \mathrm{L}$. Iron concentrations in water samples from deep monitoring well EB-145-PD5, initially less than $10 \mu \mathrm{g} / \mathrm{L}$, increased in response to pumping and continued to increase to a maximum of $740 \mu \mathrm{g} / \mathrm{L}$ until 2003, and have decreased from 2003 through 2004 (fig. 15B).

\section{Geochemical Simulations}

Saturation indices were calculated for water samples collected before, during, and after diversion activities to determine the effect on mineral solubility. Saturation indices (SI) were calculated using PHREEQC from constituent concentrations in water samples from all monitoring wells and the diversion well from March 1995 through May 2003 (table 3). The March 1995 and March 1996 samples were collected before the April 1996 aquifer test at the site (Burns and McDonnell, written commun., 1998) and, therefore, are considered prediversion samples because they were not affected by diver- 


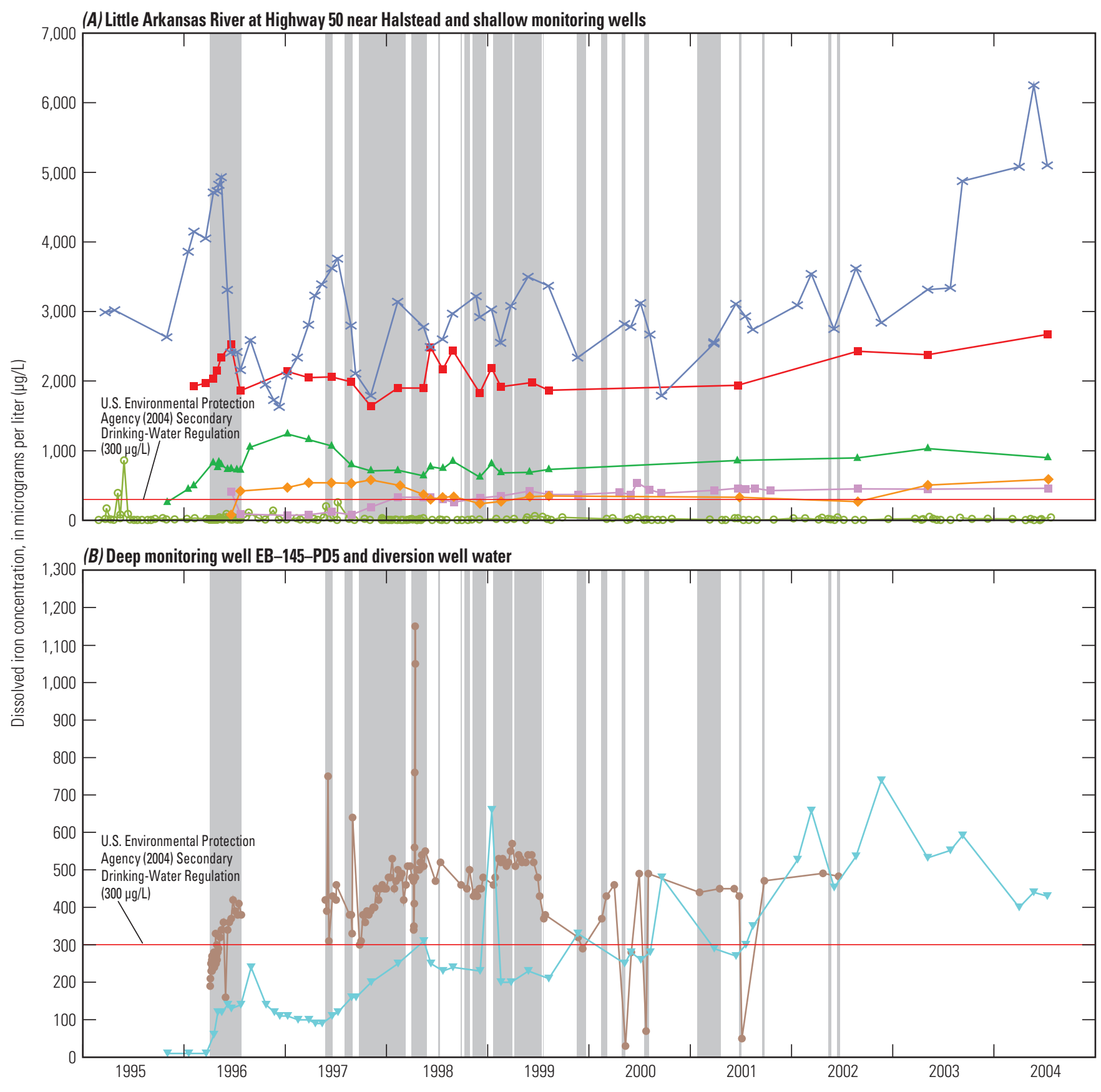

EXPLANATION

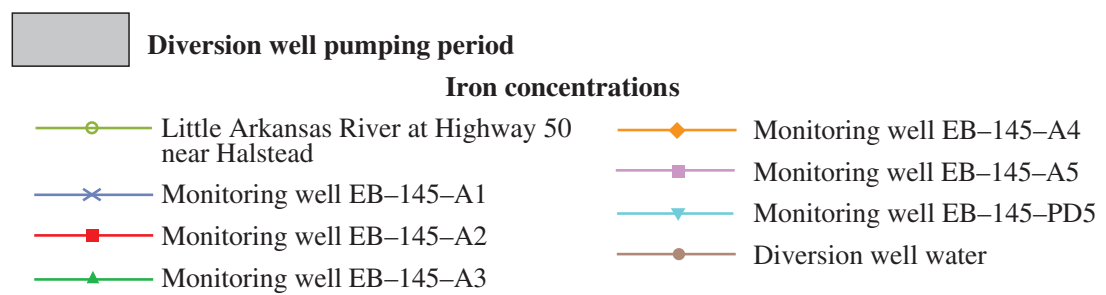

Figure 15. Iron concentrations in water samples from (A) Little Arkansas River at Highway 50 near Halstead and from shallow monitoring wells and (B) deep monitoring well EB-145-PD5 and diversion well water at Halstead diversion well site, February 1995December 2004. 
sion activities. Saturation indices with respect to calcite and dolomite (table 3 ) indicate the potential for dissolution if the minerals are present in the aquifer. However, the absence of water samples with near-equilibrium saturation indices probably indicate that calcite and dolomite are not present in the aquifer at this site.

Saturation indices with respect to amorphous ferric (iron) oxyhydroxide $\left[\mathrm{Fe}(\mathrm{OH})_{3}(\mathrm{a})\right]$ were oversaturated in water samples from wells EB-145-A1, EB-145-A2, and EB-145-A4 indicating that amorphous iron oxyhydroxide could precipitate from the water. Amorphous iron oxyhydroxide saturation indices in water from well EB-145-A3 were near equilibrium in the July 1996 sample and were oversaturated for the remainder of the study period. The July 1996 sample was collected at the end of the 75-day aquifer test. Saturation indices with respect to amorphous iron oxyhydroxide in water sampled from well EB-145-A5 were undersaturated in the July 1996 sample and oversaturated in all remaining samples throughout the study period. However, dissolved iron concentrations in shallow monitoring wells EB-145-A1 through A5 were variable (fig. 15) and did not change in response to diversion activities at the site.

Dissolved iron present in water sampled from the diversion well along with mostly oversaturated saturation indices with respect to amorphous iron hydroxides indicate the potential for iron oxyhydroxide to precipitate from this water. However, the dissolved iron in the diversion well samples is assumed to be mostly ferrous (reduced) iron because ferric iron oxyhyroxides have extremely small solubilities. Thus, the precipitation of ferric oxyhydroxides is expected to be limited unless dissolved oxygen (or other oxidants, such as nitrate) is introduced into the recharge water. Iron oxide precipitates were observed on the floors of the recharge basin and trench at the Halstead recharge site where water from the diversion well is exposed to atmospheric oxygen before being recharged into the Equus Beds aquifer.

\section{Stream-Water Mixing in Adjacent Aquifer and Solute-Transport Model}

\section{Hydrologic Conditions}

The Little Arkansas River is a gaining stream throughout most of its length in the study area, meaning that ground water flows into the river. However, at the diversion well site, a low-head dam on the river about 2 mi downstream (fig. 1) causes stream elevation at the site to be higher than groundwater levels in the adjacent aquifer resulting in waterflow from the Little Arkansas River to the aquifer (fig. 16A). During both pumping and nonpumping conditions, water levels in monitoring wells at the diversion well site responded within a few days to water-level changes in the Little Arkansas River (fig. 16B). Operation of the pumping well caused water levels in monitoring wells completed in the adjacent aquifer to decline. Maximum drawdown was $16 \mathrm{ft}$ in monitoring well EB-145-PD5, the well screened closest to the pumping well (fig. 16A). Water levels in well EB-145-A1, the well nearest to the stream, declined as much as $8 \mathrm{ft}$ during pumping.

The effect of the clay layer (described previously in "Description of Study Area") on the hydrological response of the adjacent aquifer to pumping of the diversion well was analyzed in detail by Burns and McDonnell (written commun., 1998) during an aquifer test of the diversion well that occurred before full-scale demonstration activities began. It was found that two cones of depression formed in the aquifer as a result of pumping the well. One formed in the lower part of the aquifer, beneath the clay layer, and centered over the pumping well. The other formed in the upper part of the aquifer, above the clay layer, and the center was offset to the west of the pumping well by the clay layer (Burns and McDonnell, written commun., 1998).

\section{Simple Mixing}

Piper diagrams were constructed using the median concentrations of calcium, magnesium, sodium, potassium, bicarbonate, sulfate, and chloride in water samples from the Little Arkansas River, the diversion well, and shallow monitoring well EB-145-A5 throughout the study period. The Piper diagram in figure 17 shows that median chemical concentrations in the diversion well water plot along a line drawn between the stream-water and ground-water samples, indicating that water sampled from the diversion well is a mixture of stream and ground water.

A simple mixing model (described in previous "Methods" section) was used to estimate the percentage of stream water entering the aquifer adjacent to the stream above the clay layer and also to estimate the percentage of ground water from the upper part of the adjacent aquifer reaching the diversion well in the deeper part of the aquifer. Increases in water levels in well EB-145-A1 following periods of high flow in the Little Arkansas River illustrate that the stream effectively recharges the adjacent aquifer at this site (fig. 16A). Chloride concentrations in the Little Arkansas River were temporally variable, which made it difficult to define a stream-water end member for use in the mixing model. Therefore, the median value (193 mg/L) from estimated chloride concentrations for the Little Arkansas River at Highway 50 near Halstead for 19952004 was used in the mixing model (fig. 10). This median was calculated from daily chloride concentrations estimated from continuous specific conductance or streamflow measurements. The ground-water end member chloride concentration was $32 \mathrm{mg} / \mathrm{L}$ (fig. 10), the median chloride concentration from monitoring well EB-145-A5.

The estimated mixture of water sampled from monitoring well EB-145-A1 was about 80 percent stream water and about 20 percent ground water on the basis of the end members mentioned in the previous paragraph and the median value of $159 \mathrm{mg} / \mathrm{L}$ for chloride concentrations from monitoring well EB-145-A1. This estimated mixture of water along 
Table 3. Saturation indices calculated for ground-water samples collected from Halstead diversion well site, south-central Kansas, March 1995-July 2003.

[--, not available or not calculated]

\begin{tabular}{|c|c|c|c|}
\hline \multirow[b]{2}{*}{ Date of sample } & \multicolumn{3}{|c|}{ Mineral (chemical formula) saturated indices } \\
\hline & $\begin{array}{l}\text { Calcite } \\
\left(\mathrm{CaCO}_{3}\right)\end{array}$ & $\begin{array}{c}\text { Dolomite } \\
\left(\mathrm{MgCa}\left(\mathrm{CO}_{3}\right)_{2}\right)\end{array}$ & $\begin{array}{c}\text { Amorphous iron } \\
\left(\mathrm{Fe}(\mathrm{OH})_{3}(\mathrm{a})\right)\end{array}$ \\
\hline \multicolumn{4}{|c|}{ Shallow monitoring well EB-145-A1 (fig. 2) } \\
\hline March 1995 & -0.35 & -1.37 & 1.62 \\
\hline March 1996 & -.27 & -1.20 & 1.67 \\
\hline July 1996 & -.84 & -2.32 & .85 \\
\hline June 2001 & -.67 & -1.91 & .90 \\
\hline May 2003 & -.69 & -1.98 & 1.07 \\
\hline \multicolumn{4}{|c|}{ Shallow monitoring well EB-145-A2 (fig. 2) } \\
\hline March 1995 & -- & -- & -- \\
\hline March 1996 & -.16 & -.99 & 1.58 \\
\hline July 1996 & -.64 & -1.97 & .26 \\
\hline June 2001 & -.46 & -1.56 & 1.20 \\
\hline May 2003 & -.29 & -1.23 & 1.78 \\
\hline \multicolumn{4}{|c|}{ Shallow monitoring well EB-145-A3 (fig. 2) } \\
\hline March 1995 & -- & -- & -- \\
\hline March 1996 & -- & -- & -- \\
\hline July 1996 & -.41 & -1.53 & -.02 \\
\hline June 2001 & -.47 & -1.58 & .89 \\
\hline May 2003 & -.14 & -.93 & 1.39 \\
\hline \multicolumn{4}{|c|}{ Shallow monitoring well EB-145-A4 (fig. 2) } \\
\hline March 1995 & -- & -- & -- \\
\hline March 1996 & -- & -- & -- \\
\hline July 1996 & -.33 & -1.36 & .40 \\
\hline June 2001 & -.22 & -1.10 & 1.88 \\
\hline May 2003 & -.15 & -.98 & 1.54 \\
\hline \multicolumn{4}{|c|}{ Shallow monitoring well EB-145-A5 (fig. 2) } \\
\hline March 1995 & -- & -- & -- \\
\hline March 1996 & -- & -- & -- \\
\hline July 1996 & -.41 & -1.57 & -.12 \\
\hline June 2001 & -.28 & -1.25 & 1.00 \\
\hline May 2003 & -.34 & -1.37 & .81 \\
\hline \multicolumn{4}{|c|}{ Deep monitoring well EB-145-PD5 (fig. 2) } \\
\hline March 1995 & -- & -- & -- \\
\hline March 1996 & -.05 & -.73 & .79 \\
\hline July 1996 & -.63 & -1.90 & .57 \\
\hline June 2001 & -.33 & -1.26 & 1.23 \\
\hline May 2003 & -.07 & -.74 & 2.09 \\
\hline \multicolumn{4}{|c|}{ Diversion well (fig. 2) } \\
\hline March 1995 & -- & -- & -- \\
\hline April 1996 & -.30 & -- & 1.83 \\
\hline July 1996 & -.45 & -- & .58 \\
\hline May 2000 & -.18 & -- & .25 \\
\hline
\end{tabular}




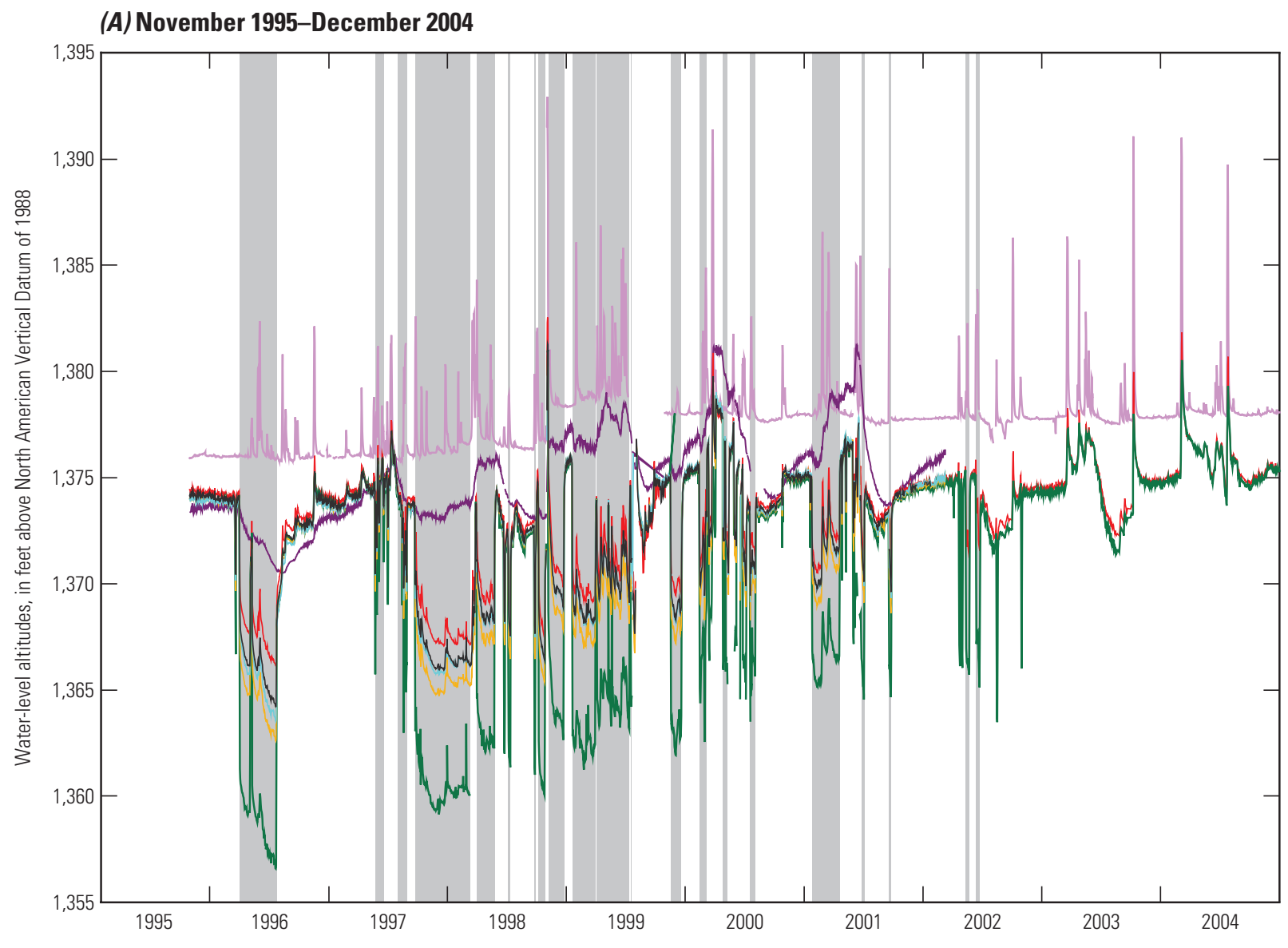

\section{EXPLANATION}

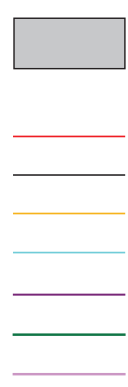

Diversion well pumping period

Water-level altitudes

Monitoring well EB-145-A1

Monitoring well EB-145-A2

Monitoring well EB-145-A3

Monitoring well EB-145-A4

Monitoring well EB-145-A5

Monitoring well EB-145-PD5

Little Arkansas River at Halstead, KS

Figure 16. (A) Water-level altitudes in monitoring wells at Halstead diversion well site and in Little Arkansas River at Halstead (site 07143680) for November 1995-December 2004 and (B) for January 2004-December 2004. Location of monitoring wells shown in figure $2 B$. Location of stream-gaging site shown in figure 1.

with water-level evidence demonstrate recharge of the adjacent aquifer by the stream. The estimated mixture of water sampled from the diversion well (median concentration $60 \mathrm{mg} / \mathrm{L}$ ) was about 25 percent water from monitoring well EB-145-A1 and about 75 percent from ground water.

The presence of atrazine in water samples from deep monitoring well EB-145-PD5 and in water samples from the diversion well indicates the migration of stream water into the deeper part of the adjacent aquifer. One advantage of using the induced stream-water recharge approach to capture stream water for use in artificial recharge is that organic compounds, such as atrazine, are sorbed by or attached to aquifer material as the water moves into the adjacent aquifer. The average concentration of atrazine in the Little Arkansas River at Highway 50 near Halstead from 1999 through 2004 was $2.4 \mu \mathrm{g} / \mathrm{L}$. The average atrazine concentration in monitoring well EB-145-A1 was $0.45 \mu \mathrm{g} / \mathrm{L}$. If mixing model percentages of 80 percent surface water and 20 percent ground water in monitoring well EB-145-A1 are applied to average atrazine concentrations from the surface water $(2.4 \mu \mathrm{g} / \mathrm{L})$ and ground water $(0.05 \mu \mathrm{g} / \mathrm{L})$, the resulting estimated average atrazine concentrations in well EB-145-A1 is $1.93 \mu \mathrm{g} / \mathrm{L}$. The estimated atra- 
(B) January 2004-December 2004

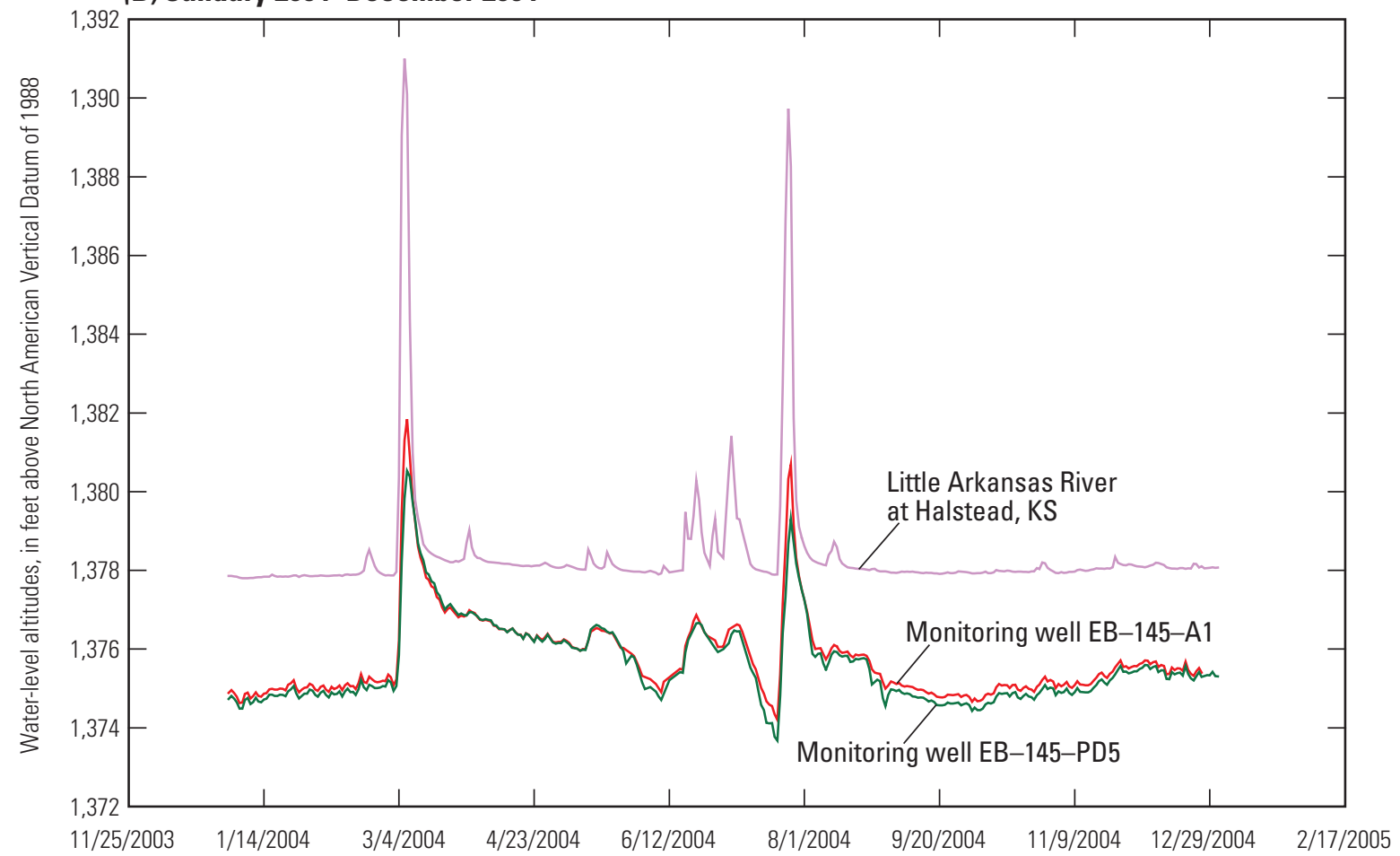

Figure 16. (A) Water-level altitudes in monitoring wells at Halstead diversion well site and in Little Arkansas River at Halstead (site 07143680) for November 1995-December 2004 and (B) for January 2004-December 2004. Location of monitoring wells shown in figure $2 B$. Location of stream-gaging site shown in figure 1-Continued.

zine concentration is much larger than the measured average atrazine concentration of $0.45 \mu \mathrm{g} / \mathrm{L}$ in water sampled from this well, indicating a large amount (about 75 percent) of atrazine likely is sorbed to the aquifer material.

\section{Flow and Solute-Transport Model}

Flow and transport simulations were performed with the solute-transport model PHAST (Parkhurst and others, 2004) to better evaluate the quantity of flow between the Little Arkansas River and the diversion well at the Halstead diversion well site. The model was calibrated to drawdown data at six monitoring wells and then used to simulate the transport of stream-derived chloride to the diversion well over a period of 10 years. Results are used to provide a preliminary estimate of mixing of stream water and ground water at the diversion well.

\section{Model Definitions and Flow Simulations}

Burns and McDonnell (written commun., 1998) conducted aquifer tests and developed a subregional model for the area including the Halstead diversion site. The hydraulic conductivity (K) in subregional model was $60 \mathrm{ft} / \mathrm{d}$ for sand and gravel layers. Transmissivity of clay layer was $359 \mathrm{ft}^{2} / \mathrm{d}$ and a storativity of 0.02 . The grid spacing was $1,000 \mathrm{ft}$.

The flow model described in this report was developed in metric units with an assigned vertical datum of $50 \mathrm{~m}$. For this report, spatial data from the model have been converted to feet and rounded to the nearest $0.1 \mathrm{ft}$. Altitudes and hydraulic heads are reported relative to NAVD 88, and the 50-m vertical datum represents an altitude of $1,390 \mathrm{ft}$, which is approximately land-surface altitude at the Halstead recharge site. The model considered the effects of pumpage on an initially flat water table and a stream that was maintained at a water level $2 \mathrm{ft}$ above the initial water table. Water was allowed to flow in through the side boundaries of the model domain through leaky boundary conditions. Precipitation recharge and the regional hydraulic-head gradients were ignored.

Horizontal model-grid coordinates ranged from -8,202.1 to $+8,202.1 \mathrm{ft}$ in the $\mathrm{x}$ and $\mathrm{y}$ directions, with coordinate $\mathrm{x}=0$, $\mathrm{y}=0$ at the diversion well. Horizontal grid nodes were variably spaced with closest spacing near the diversion well $(13.1 \mathrm{ft})$, fractionally increasing to the largest spacing at the borders $(1,380.4 \mathrm{ft})$. Constant node spacing of $32.6 \mathrm{ft}$ was overlaid on the $\mathrm{x}$ axis from $\mathrm{x}=0$ to $\mathrm{x}=300$ to enhance resolution in the vicinity of the Little Arkansas River. The y axis of the grid was rotated about 15 degrees counterclockwise relative to north so that it was aligned with the Little Arkansas River north of the observation wells (fig. 18). Vertical grid coordinates ( $\mathrm{z}$ direction) ranged from 1,252.9 to 1,390.0 ft. Vertical grid spacing was $16.4 \mathrm{ft}$ below 1,324.4 ft altitude and $8.2 \mathrm{ft}$ above that altitude. The total numbers of grid nodes in each direction were 70 (x direction), 53 (y direction), and 12 ( $\mathrm{z}$ direction). 


\section{EXPLANATION}

$\star$ Little Arkansas River at Highway 50 near Halstead

- Diversion well

- Monitoring well EB-145-A5

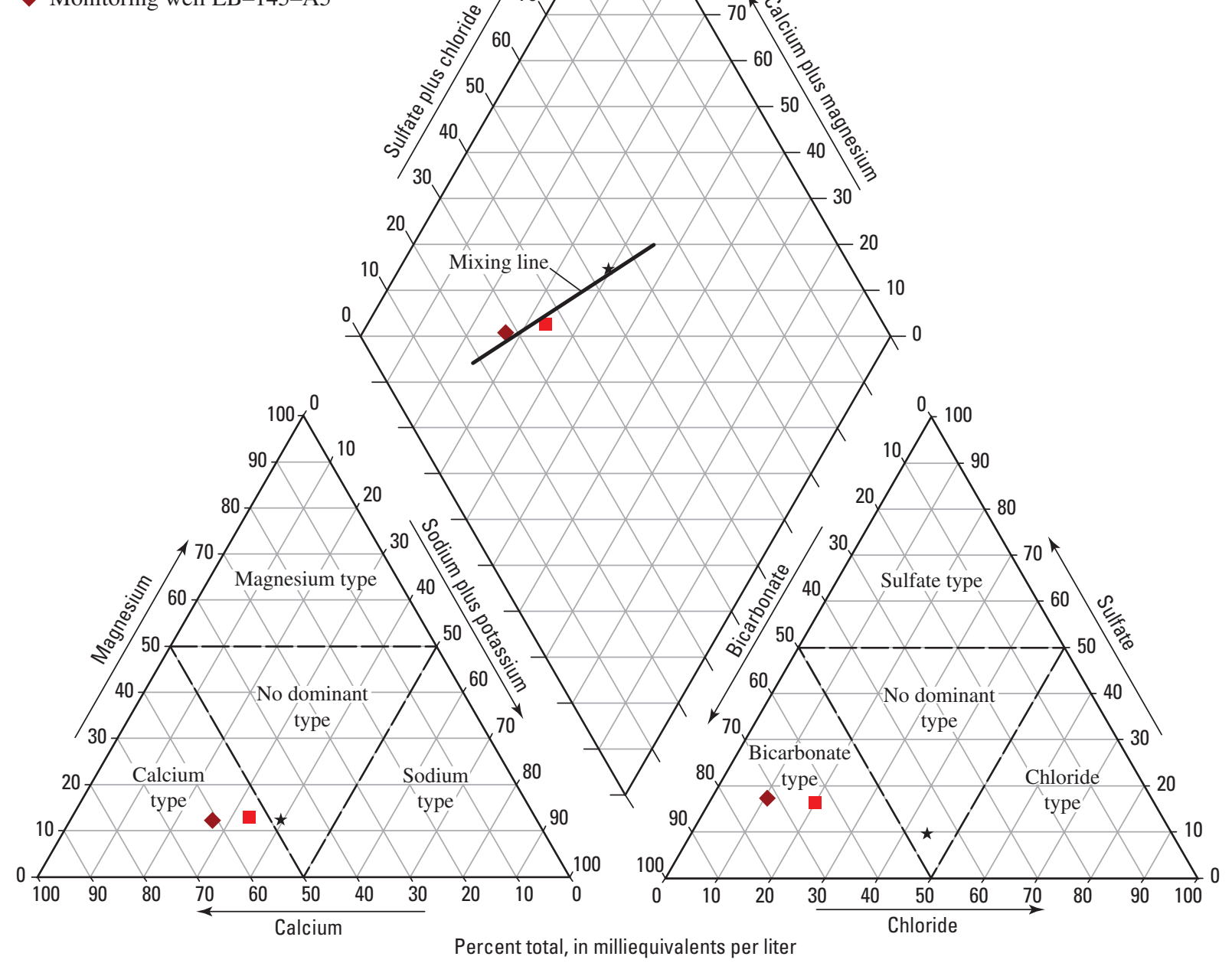

Figure 17. Median major ion chemistry in water samples from Little Arkansas River at Highway 50 near Halstead, diversion well, and shallow monitoring well EB-145-A5 at the Halstead diversion well site.

Moving upward from an assumed impermeable shale boundary at $1,252.9 \mathrm{ft}$, the hydrologic units considered in the model included a lower sand and gravel aquifer from 1,252.9 to $1,324.4 \mathrm{ft}$, a lower clay layer from $1,324.4$ to $1,340.8 \mathrm{ft}$, an upper sand and gravel aquifer from 1,340.8 to $1,365.4 \mathrm{ft}$, and an upper clay layer from $1,365.4$ to $1,390.0 \mathrm{ft}$. On the basis of lithologic information from the monitoring wells and the offset in the drawdown cones in the upper and lower aquifers during the April 1996 aquifer test, a sand and gravel window in the lower clay layer was included that ranged from $-1,148.3$ to $-164.0 \mathrm{ft}$ in the $\mathrm{x}$ direction and -328.1 to $328.1 \mathrm{ft}$ in the y direction.

The model had a free-surface boundary condition (unconfined flow), which uses the porosity as the specific storage in a cell that contains the water table and zero for specific storage in all cells not containing the water table. The stream boundary ran from top to bottom of the simulation area with a kink near the pumping well (light blue line, fig. 18). The multicolored patches surrounding the stream (fig. 18) defined hydraulic conductivity to be equal to the aquifer hydraulic conductivity from $1,365.4$ to $1,390.0 \mathrm{ft}$ altitude. For the rest of the domain, this altitude corresponds to the upper clay layer. Thus, the stream connects directly to the aquifer (not the upper clay layer), and all the resistance to flow from stream to aquifer is represented by the streambed hydraulic conductivity.

Leaky boundaries were applied at all four vertical sides of the domain. These boundaries had a constant hydraulic head $(1,373.9 \mathrm{ft})$ at a distance of $3,280.8 \mathrm{ft}$ from the edges. The diversion well pumped $978 \mathrm{gal} / \mathrm{min}$ over a 114.5 -day period representing April 1 through July 24, 1996, with an off period of 6 days in early May when pumping was suspended.

Drawdown data at six monitoring wells [EB-145-A1, EB-145-A2, EB-145-A3, EB-145-A4, EB-145-A5, and EB-145-PD5 (line of yellow dots in fig. 18)] were used to 
calibrate the flow model. Simulated hydraulic heads were calibrated to 13 points spaced at 10-day intervals at each of the six monitoring wells that spanned the pumping and recovery period (last 2 points) of the 1996 aquifer test. All data were given a 0.33 -ft standard deviation for the fitting except the data at day 40 , which were given a 3.28-ft standard deviation because of the sensitivity of the hydraulic heads to the time pumping was restarted on day 39, following the end of downtime in early May.

Parameters fit by UCODE (Poeter and Hill, 1998) included a single hydraulic conductivity for the upper and lower aquifer, which applied to the sand and gravel window in the upper clay as well and the zones connecting the stream to the aquifer; a single hydraulic conductivity for the upper and lower clay layers; and the streambed leakance. Other fixed parameters were as follows: porosity, 0.3 ; isotropic dispersivity, $16.4 \mathrm{ft}$; initial hydraulic head, 1,373.9 ft; stream width, $98.4 \mathrm{ft}$; streambed thickness, $3.28 \mathrm{ft}$; and stream altitude, $1,375.9 \mathrm{ft}$ ( $2 \mathrm{ft}$ above initial hydraulic head). The total simulation time was 130 days, with a time step of 2 days.

Fit values were aquifer hydraulic conductivity $(\mathrm{K})$, $50.1 \mathrm{ft} / \mathrm{d}$; clay layer hydraulic conductivity, $0.069 \mathrm{ft} / \mathrm{d}$; and streambed leakance, 0.029 (1/d). These values are similar to those used by Burns and McDonnell (written commun., 1998). Contours for the simulated drawdown at the end of the pumping period of the aquifer test (maximum drawdown) are shown in figure $19 A$ for the upper and figure $19 B$ for the lower aquifer units along with measured drawdowns in the observation wells. The general features of the measured drawdown are captured by the model, but there are discrepancies at individual wells. Figures $20 A-F$ show the measured drawdowns compared to the simulated drawdowns for each monitoring well. Actual and simulated drawdowns are similar for all monitoring wells. The lack of recovery of water levels in well EB-145-A5 after pumping was not possible to simulate; however, this well was the farthest from the pumping well, and during the rest of the study, water levels at this well did not always respond to pumping at the diversion well. Therefore, other factors may affect water levels in well EB-145-A5.

\section{Solute Transport}

The calibrated parameters for the flow system were used in the simulation of chloride transport. For the initial condition, chloride was distributed linearly with distance from the stream (fig. 21); fractional concentration was 1 at the stream and 0 at a distance of $656.2 \mathrm{ft}$, which is consistent with chloride concentrations in the monitoring wells. This profile applied to water in the upper clay layer $(1,332.6 \mathrm{ft})$ to the land surface. Pumping at a rate of $978 \mathrm{gal} / \mathrm{min}$ was simulated for a period of 10 years. The model time step was variable from

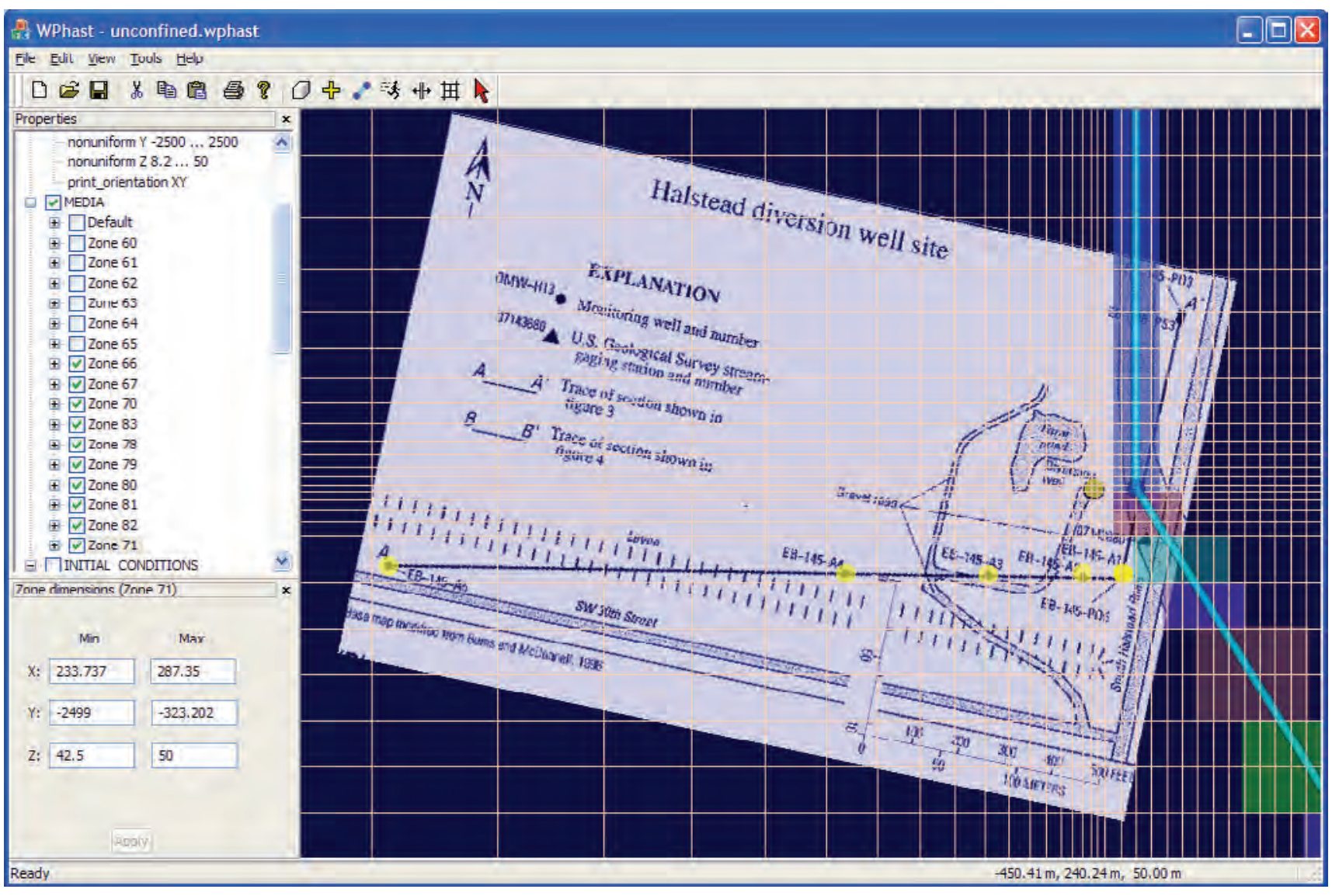

Figure 18. Model grid for the flow and solute-transport model at the Halstead diversion well site. 


\section{(A) Shallow observation wells}

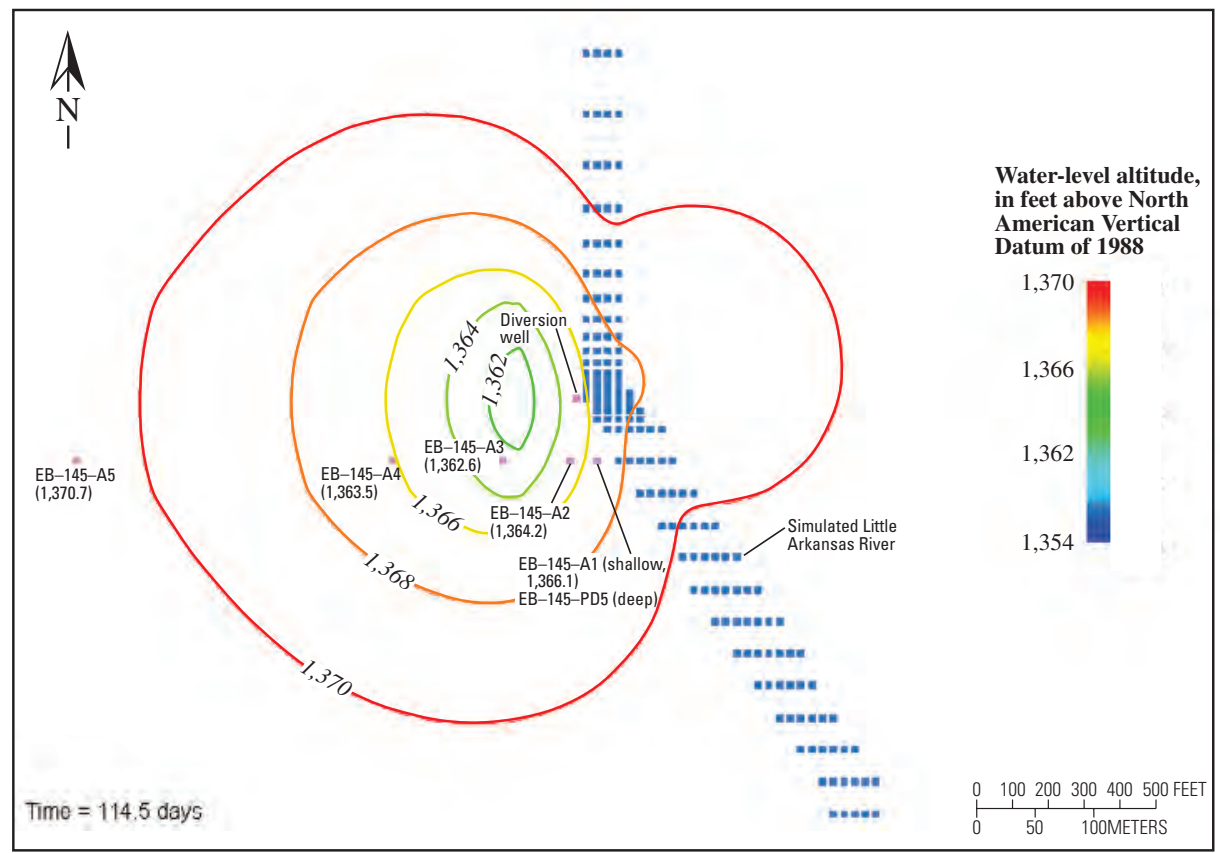

\section{(B) Deep observation wells}

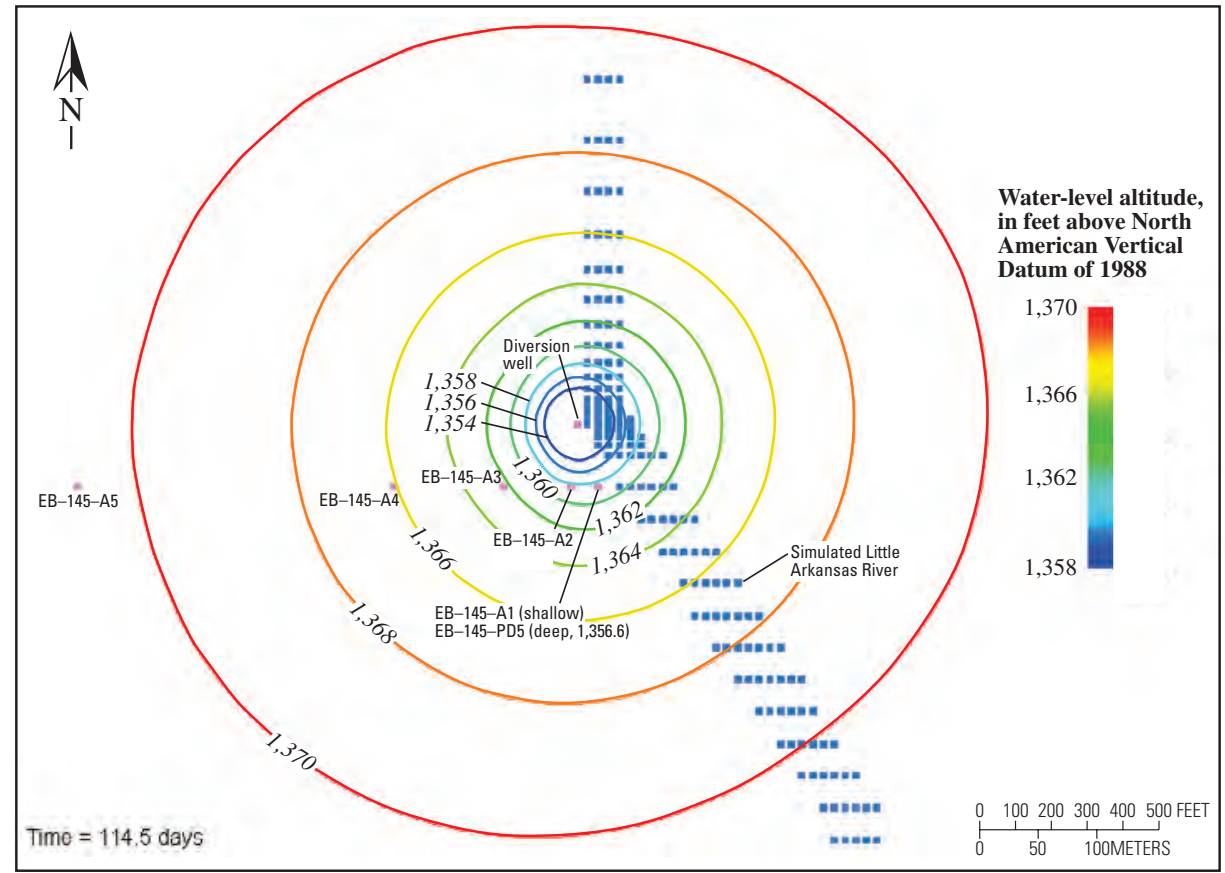

EXPLANATION

— 1,370 - Water-level contour-Shows altitude of water level. Contour interval 2 feet. Datum is North American Vertical Datum of 1988

EB-145-A5 " Observation well-Upper number is observation well identifier. Number in parentheses ( ) is water-level altitude, in feet above North American Vertical Datum of 1988

Figure 19. Simulated water-level contours for the $(A)$ upper and $(B)$ lower parts of the aquifer adjacent to the Little Arkansas River at the Halstead diversion well site. 
(A) EB-145-A1

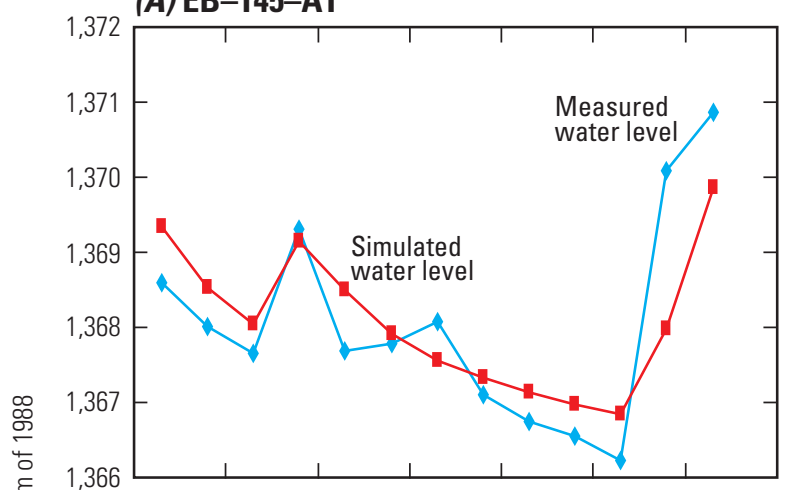

(B) EB-145-A2

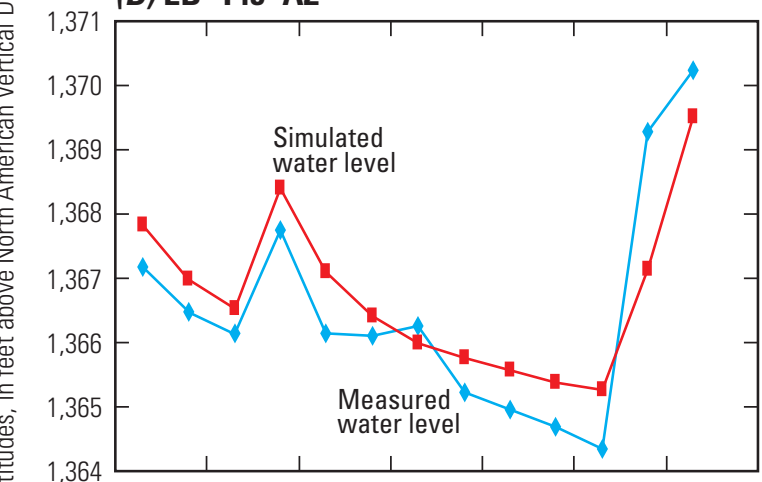

(C) EB-145-A3

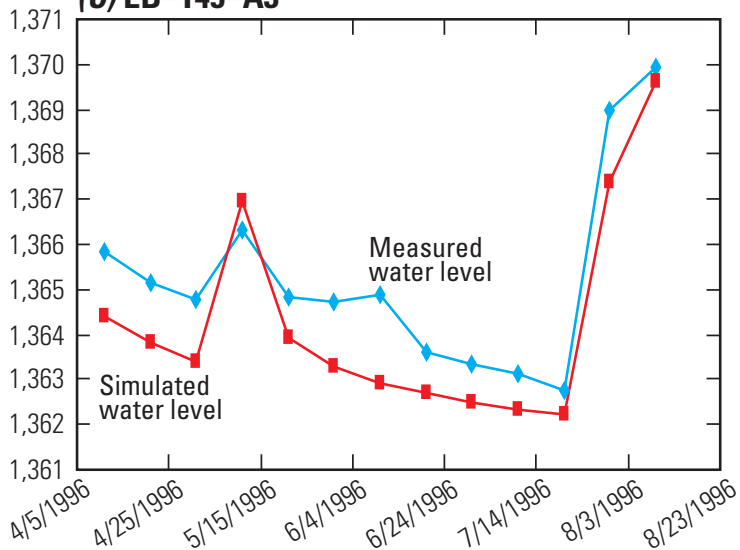

(D) EB-145-A4

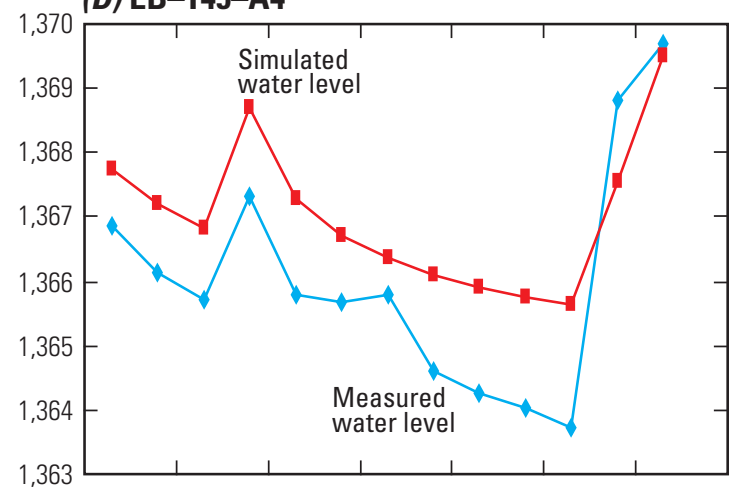

(E) EB-145-A5
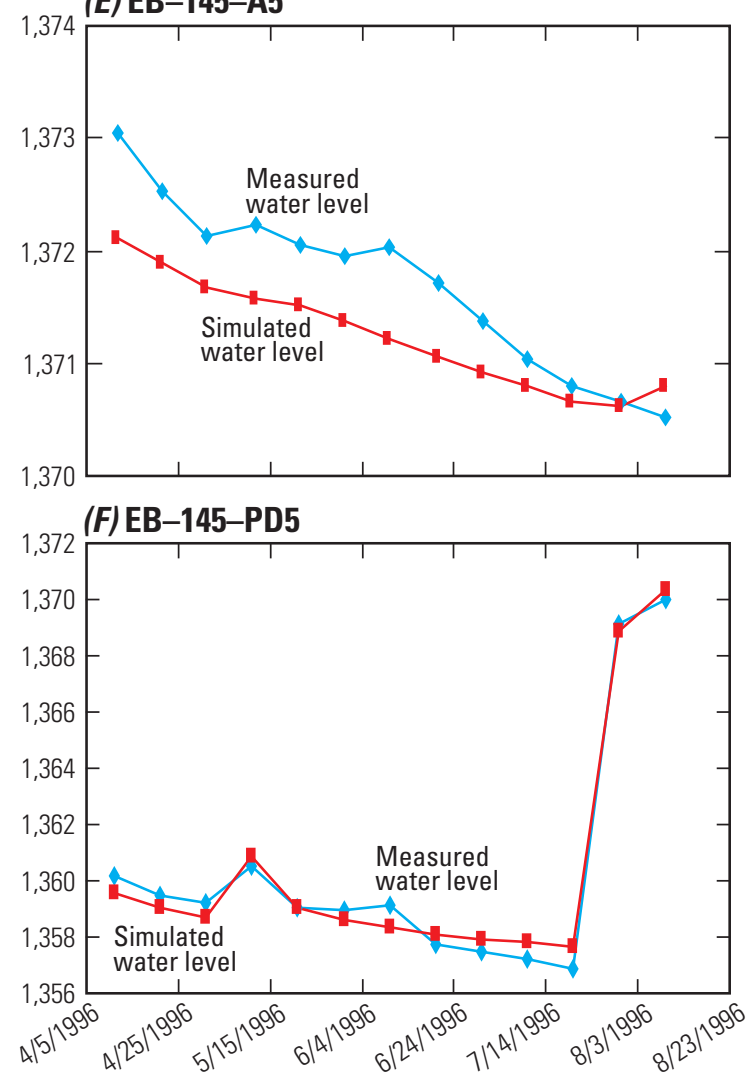

Figure 20. Simulated and measured water-level response to pumping at the Halstead diversion well site.

1 minute to 0.05 year. All induced recharge from the stream had a fractional concentration of 1.0. The distribution of chloride with time and the concentration of chloride in the pumping well were simulated.

Initially, the simulated rate of induced recharge, as determined by flow through the river boundary condition, is about 55 percent of the pumping rate; the remainder of the water pumped is taken from storage within the aquifer. The simulated rate of induced recharge increases over several years of pumping. After 10 years, the simulated rate of induced recharge is about 75 percent of the pumping rate; the rate of flow through the leaky boundaries at the edges of the domain is about 24 percent of the pumping rate; and the rate of change in storage is about 1 percent of the pumping rate. Thus, the simulation results indicate that the flow system is nearly at steady state after 10 years of continuous pumpage.

Chloride concentrations in the diversion well increase rapidly in the simulation and are similar to measured chloride concentrations in water sampled from the well (fig. 22 and fig. 10). The initial plateau in measured chloride concentration at the diversion well was about 20 percent of the concentration in stream water; the simulated concentration is less than 25 percent. However, the similarity is based on the assumed initial chloride concentrations in the aquifer. At steady state in the model, the concentration of chloride at the diversion well will be equal to the fraction of water derived from the stream. 


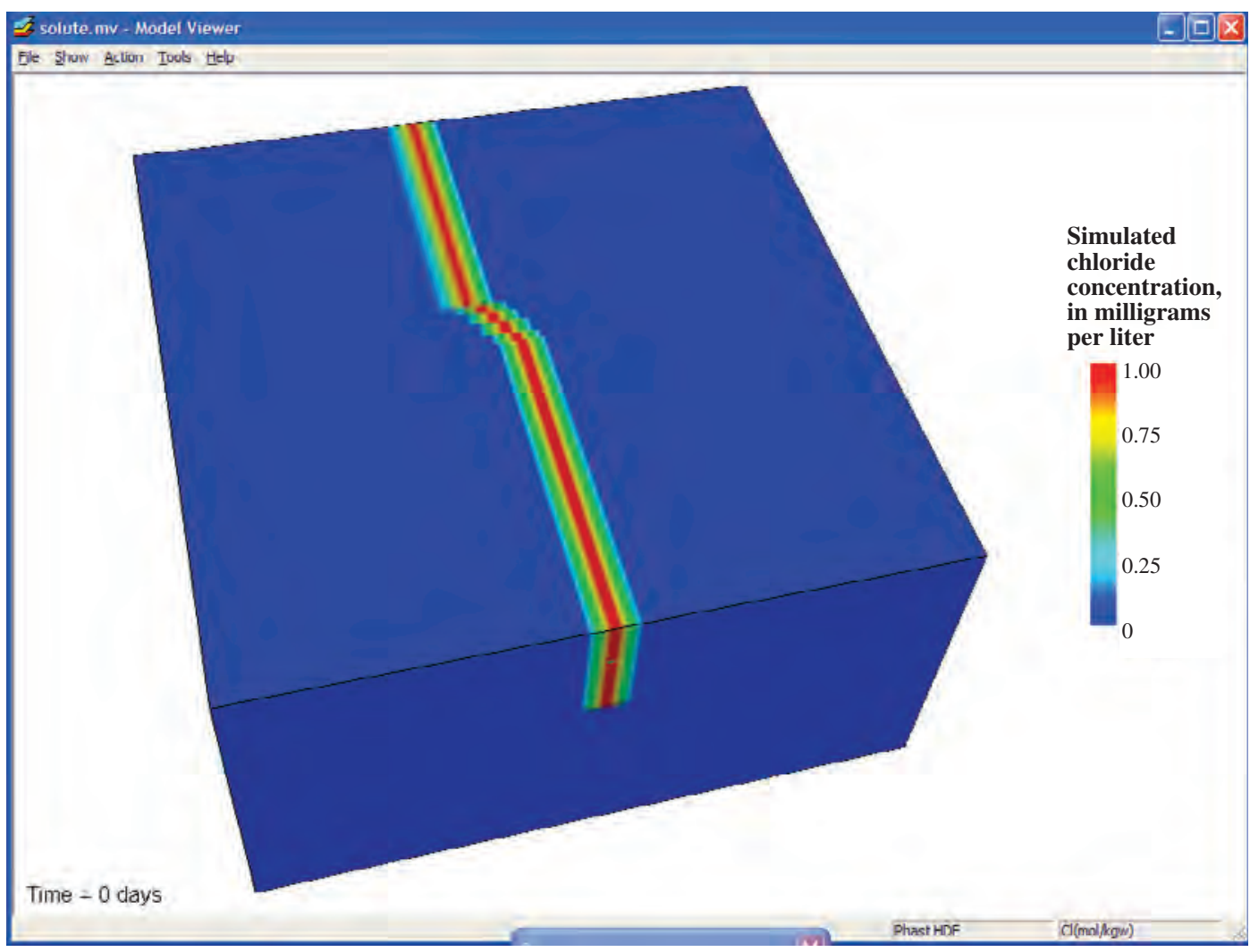

Figure 21. Initial chloride distribution for solute-transport model at the Halstead diversion well site.

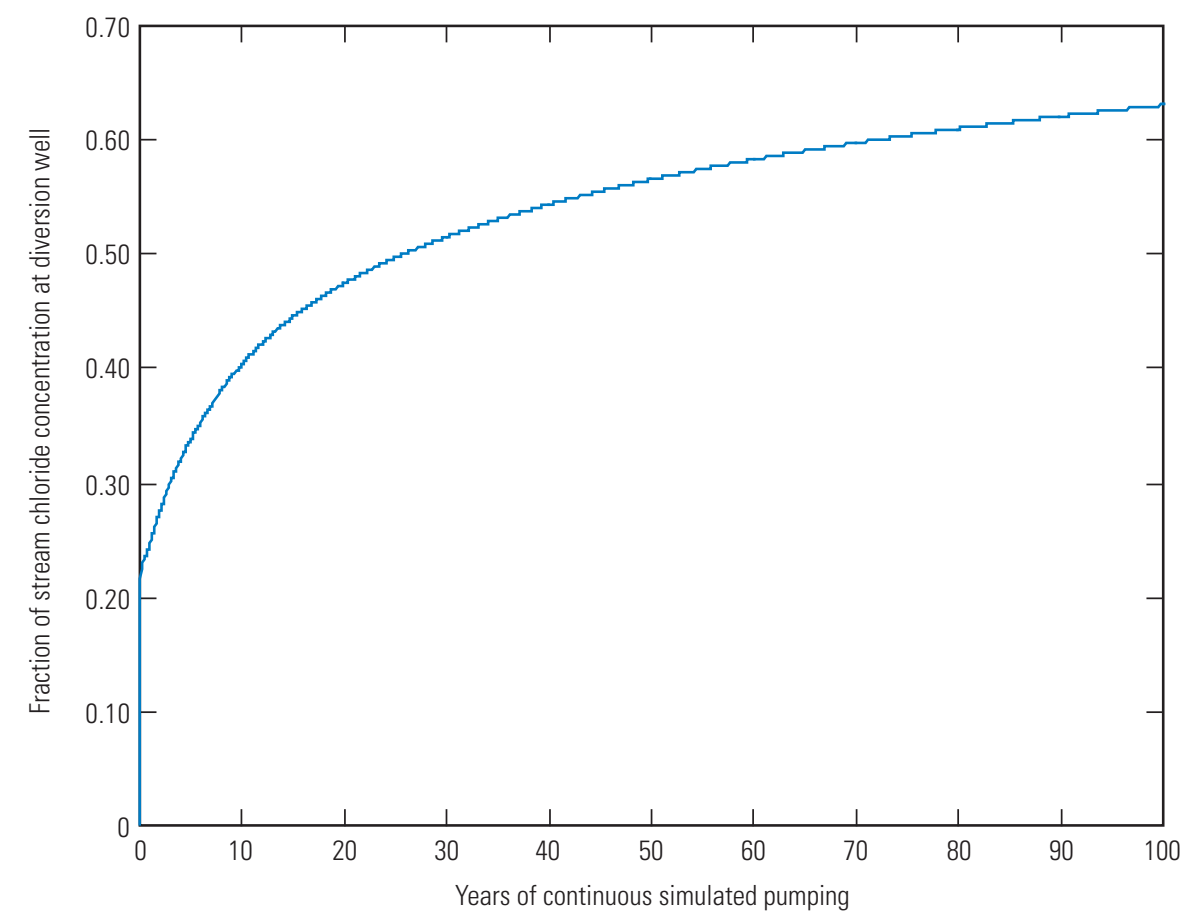

Figure 22. Simulated fraction of stream chloride concentration in Halstead diversion well over a 100-year simulation. 
Thus, ultimately (after decades) the water pumped will have a chloride concentration approximately equal to 75 percent of the concentration of water in the stream.

In summary, flow and transport simulation results indicate that with continuous pumpage the flow system requires decades to achieve steady state. At steady-state flow, the rate of induced recharge is simulated to be about 75 percent of the pumping rate. Initial chloride concentrations in the diversion well are dependent on the chloride distribution in the aquifer at the beginning of pumpage. It requires a decade for simulated chloride concentrations in the diversion well to be representative of the rate of induced stream-water recharge.

This model is limited to qualitative application and is a simplification of the natural system. This model simulates continuous pumping of the diversion well, which will not occur because of the permit restrictions; therefore, it likely will take more time to reach equilibrium. Regional gradients to and along the river, natural recharge, evapotranspiration, and other factors have been ignored. This model and the simple mixing model both qualitatively illustrate that a substantial portion of water in the diversion well originates from the stream. However, the initial pumped water contains a large proportion of water from the aquifer, and many years may be required to reach steady-state conditions with the larger contribution from the stream.

\section{Geochemical Effects of Artificial Recharge at Halstead Recharge Site}

The Equus Beds aquifer at the Halstead recharge site was artificially recharged through surface-spreading recharge basins, a recharge trench, and a direct injection recharge well (fig. 2B); therefore, possible geochemical effects depend on the method of artificial recharge. Potential issues for artificial recharge through the injection well at the Halstead site include the formation of mineral precipitates because of reactions between the recharge water and the existing ground water. Changes in $\mathrm{pH}$ and redox potential caused by artificial recharge could affect the mobility of dissolved arsenic concentrations at the Halstead site. Also, the precipitation of iron minerals from existing ground water is a potential concern because the recharge of water with $\mathrm{pH}$ and redox potential in the range of ferric iron could stimulate growth of iron bacteria.

\section{Major Ion Chemistry and Tracers of Recharge Water}

Piper diagrams were created for water sampled from shallow and deep monitoring wells at the Halstead recharge site. The diagrams presented in figures $23 A-C$ depict the major ion chemistry in May 1997, May 1999, and April 2003 at the Halstead recharge site. Samples collected during May 1997 were collected before artificial recharge began at the site and are considered baseline samples at the site. The water type for samples from shallow and deep monitoring wells SMW-H4, DMW-H1, and DMW-H13 is calcium bicarbonate, meaning that calcium is the dominant cation and bicarbonate is the dominant anion. Initial chloride concentrations in wells SMW-H4, DMW-H1, and DMW-H13 were less than $50 \mathrm{mg} / \mathrm{L}$ before artificial recharge operations began in May 1997 (fig. 24).

Water sampled from the shallow monitoring well SMW-H14 is a sodium chloride type water and noticeably different than water sampled from the other monitoring wells at the Halstead site. The initial chloride concentration in water from shallow monitoring well SMW-H14 was about $280 \mathrm{mg} / \mathrm{L}$, which was greater than the $250-\mathrm{mg} / \mathrm{L}$ SDWR. The larger chloride concentrations and the sodium chloride water type in the sample from well SMW-H14 can be attributed to the well's proximity to the sewage treatment lagoon located to the southeast of the recharge site (Ziegler and others, 1999). Piper plots show that water samples from well SMW-H14 evolved to calcium-bicarbonate-type water during artificial recharge and reverted to sodium-chloride-type water after artificial recharge activities ended (fig. 23). During the period of artificial recharge through the basins, trench, and direct injection, all monitoring wells had essentially the same major ion composition.

Water sampled from shallow monitoring wells showed evidence of recharge water soon after artificial recharge began through the recharge basins and trench. Chloride concentrations decreased in samples from shallow monitoring well SMW-H14 from $280 \mathrm{mg} / \mathrm{L}$ and increased in chloride concentrations in samples from shallow monitoring well SMW-H4 from $20 \mathrm{mg} / \mathrm{L}$ to about $60 \mathrm{mg} / \mathrm{L}$, the concentration of chloride in recharge water (fig. 24). Deep monitoring wells showed evidence of recharge water after the injection well was used for artificial recharge. Chloride concentrations in water sampled from deep monitoring wells DMW-H1 and DMW-H13 increased from about 8 to about $60 \mathrm{mg} / \mathrm{L}$ and remained constant throughout the study period except for a concentration of about $130 \mathrm{mg} / \mathrm{L}$ in a sample from well DMW-H13 in April 1999 (fig. 24).

Chloride concentrations in samples from all monitoring wells remained similar to recharge water concentrations during active artificial recharge through the recharge basins and trench from May 1997 through August 2000. After artificial recharge ended through the recharge basins and trench in 2001, the chloride concentrations in water sampled from well SMW-H14 increased to before-recharge concentrations of between 100 and $420 \mathrm{mg} / \mathrm{L}$. Chloride concentrations decreased from about 50 to about $30 \mathrm{mg} / \mathrm{L}$ in water sampled from well SMW-H4. The response of chloride concentrations in water from the shallow monitoring wells indicates a displacement of the ground water in the immediate area at the site rather than mixing. Chloride concentrations in the deep monitoring wells have remained around $60 \mathrm{mg} / \mathrm{L}$ since the end of recharge operations.

Atrazine concentrations in water from the shallow monitoring wells at the Halstead recharge site also indicate when 


\section{(A) May 1997}

\section{EXPLANATION}

$\checkmark$ Monitoring well SMW-H14

• Monitoring well SMW-H4

- Monitoring well DMW-H1

- Monitoring well DMW-H13

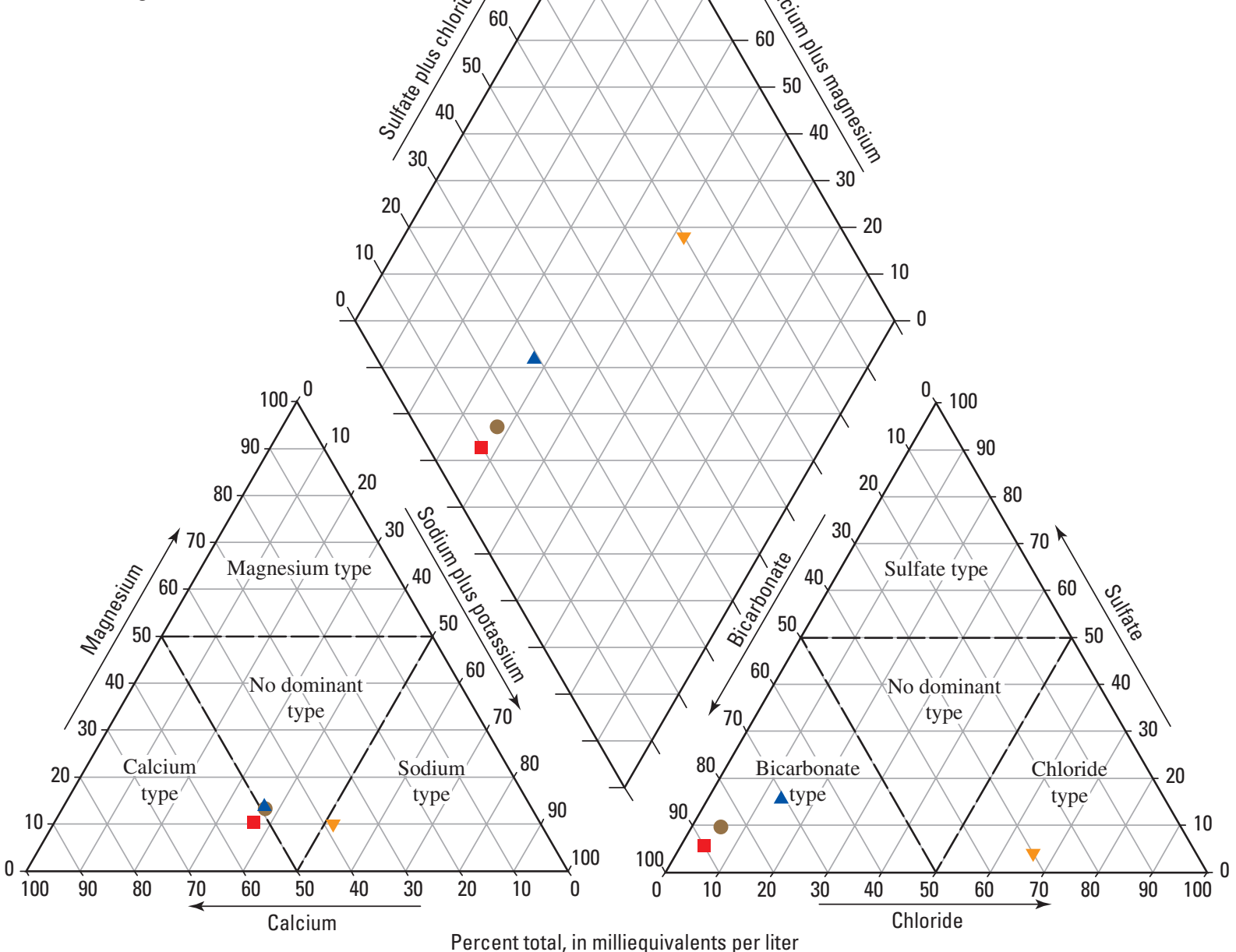

Figure 23. Major ion chemistry in water samples from the Halstead recharge site in (A) May 1997, (B) May 1999, and (C) April 2003.

artificial recharge began through the recharge basins (May 1997), and concentrations in water from the deep monitoring wells indicate when recharge by injection well began (August 1997) (fig. 25). The before-recharge concentration in the sample from well SMW-H4 was $0.14 \mu \mathrm{g} / \mathrm{L}$, which was larger than the average concentration in samples of recharge water (less than $0.10 \mu \mathrm{g} / \mathrm{L}$ ), and the before-recharge concentration in a sample from well SMW-H14 was less than $0.10 \mu \mathrm{g} / \mathrm{L}$ and equal to the average concentration in recharge water. After recharge began, atrazine concentrations in water from the shallow monitoring wells at the Halstead recharge site were similar to concentrations in the recharge water. Concentrations in shallow monitoring wells generally were $0.15 \mu \mathrm{g} / \mathrm{L}$ or less, but occasionally concentrations ranged between 0.25 and $0.50 \mu \mathrm{g} / \mathrm{L}$; large concentrations were measured more frequently toward the end of the sampling period. Atrazine concentrations in the final samples from the shallow monitoring wells (2004) were approximately $0.25 \mu \mathrm{g} / \mathrm{L}$. Atrazine concentrations in deep monitoring wells increased when artificial recharge by injection began in August 1997. Concentrations were variable, occasionally in the range of 0.10 to $0.20 \mu \mathrm{g} / \mathrm{L}$. Atrazine concentrations in all samples were considerably less than the USEPA MCL of $3.0 \mu \mathrm{g} / \mathrm{L}$ as an annual average. The changes in atrazine concentrations correspond with the changes in chloride concentrations and indicate the presence of recharge water in the Equus Beds aquifer at the Halstead site. 


\section{(B) May 1999}

\section{EXPLANATION}

$\nabla$ Monitoring well SMW-H14

• Monitoring well SMW-H4

- Monitoring well DMW-H1

- Monitoring well DMW-H13

$\checkmark$ Diversion well

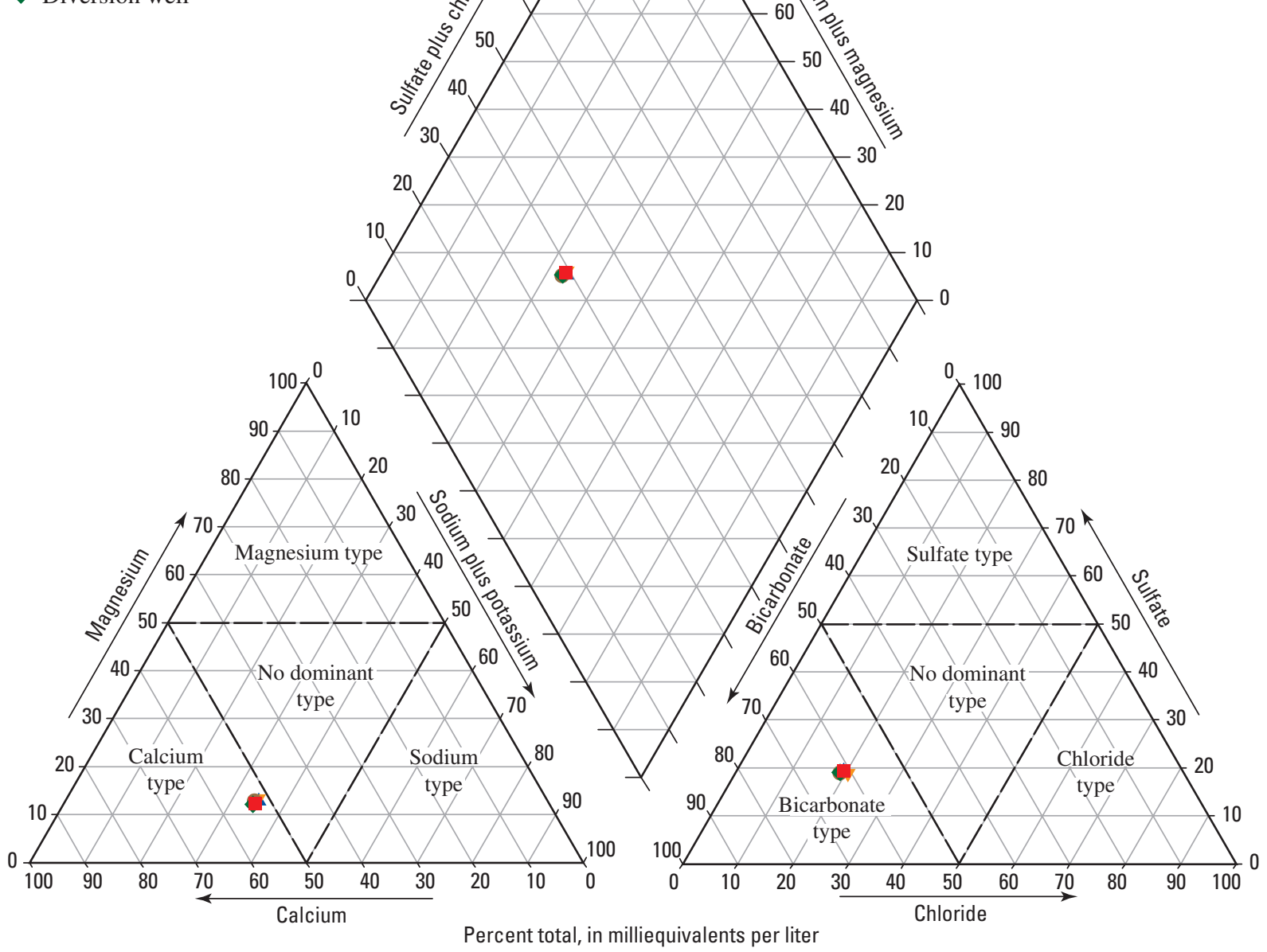

Figure 23. Major ion chemistry in water samples from the Halstead recharge site in (A) May 1997, (B) May 1999, and (C) April 2003Continued.

\section{Selected Trace Metal Chemistry}

At the Halstead recharge site, the pre-recharge concentrations of arsenic were less than $5.0 \mu \mathrm{g} / \mathrm{L}$ in samples from the shallow monitoring wells (fig. 26). Arsenic concentrations in water from the shallow monitoring wells did not increase because of artificial recharge at the site despite the median arsenic concentration of $20 \mu \mathrm{g} / \mathrm{L}$ in the recharge (diversion well) water (fig. 26). Ferric oxyhydroxide percipitates have been observed in the recharge basins and trench at the Halstead recharge site, and it is likely that sorption or co-precipitation of arsenic with ferric oxyhydroxides sequesters arsenic (Welch and others, 2000) before water recharges through the basins and trench.
The initial arsenic concentrations in water sampled from monitoring wells DMW-H1 and DMW-H13 were 8.6 and $11 \mu \mathrm{g} / \mathrm{L}$, respectively. Arsenic concentrations in water from the deep monitoring well DMW-H1 increased because of artificial recharge. Median concentrations increased to $20 \mu \mathrm{g} / \mathrm{L}$ in samples from well DMW-H1 after injection began in August 1997 (fig. 26). Arsenic concentrations at this monitoring well were similar to concentrations in the recharge (diversion well) water and increased in a similar pattern as the conservative constituent chloride. Arsenic concentrations likely increased as a result of the influx of the recharge water near monitoring well DMW-H1. Direct injection of recharge water likely allowed less contact with the atmosphere than water recharge through the basins and trench. Thus, precipi- 


\section{(C) April 2003}

\section{EXPLANATION}

v Monitoring well SMW-H14

^ Monitoring well SMW-H4

- Monitoring well DMW-H1

- Monitoring well DMW-H13

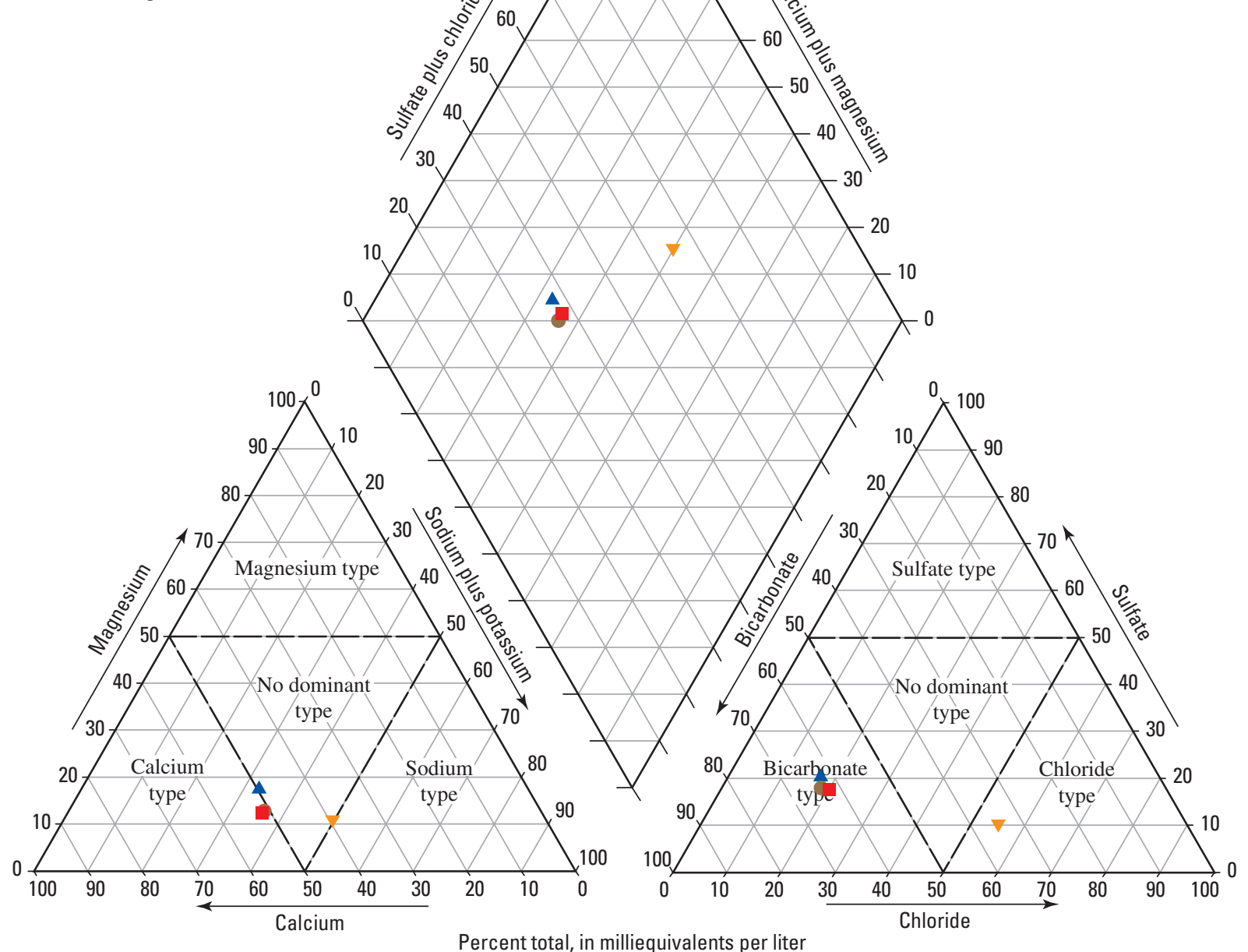

Figure 23. Major ion chemistry in water samples from the Halstead recharge site in (A) May 1997, (B) May 1999, and (C) April 2003Continued.

tation of ferric oxyhydroxides did not occur, which allowed large arsenic concentrations in the recharge water to be introduced directly into the aquifer.

Iron was detected only four times in water collected from shallow monitoring wells SMW-H4 and SMW-H14. Concentrations in the shallow monitoring wells ranged from less than 5 to $46 \mu \mathrm{g} / \mathrm{L}$ and were substantially less than the USEPA SDWR of $300 \mu \mathrm{g} / \mathrm{L}$ (U.S. Environmental Protection Agency, 2004) (fig. 27). The iron concentrations in shallow monitoring wells at the site also were substantially less than the median iron concentration of $430 \mu \mathrm{g} / \mathrm{L}$ in the recharge (diversion well) water.

Iron concentrations in water from the deep monitoring wells at the Halstead recharge site were larger than in shal- low monitoring wells and increased after injection of recharge water. Iron concentrations in water samples from monitoring well DMW-H1 were about $20 \mu \mathrm{g} / \mathrm{L}$ before injection but increased steadily to greater than $200 \mu \mathrm{g} / \mathrm{L}$ after injection recharge began in August 1997. Similar to arsenic concentrations, the iron concentrations in samples from deep well DMW-H1 indicated mixing with the recharge water and not necessarily a change in the geochemical environment. Iron concentrations in the water sampled from deep monitoring well DMW-H13 increased after injection recharge began and were substantially larger than iron concentrations in the recharge (diversion well) water (fig. 27). This mobilization of iron could be caused by reduction of ferric oxyhydroxides, increased bacterial activity, or some other change in the 


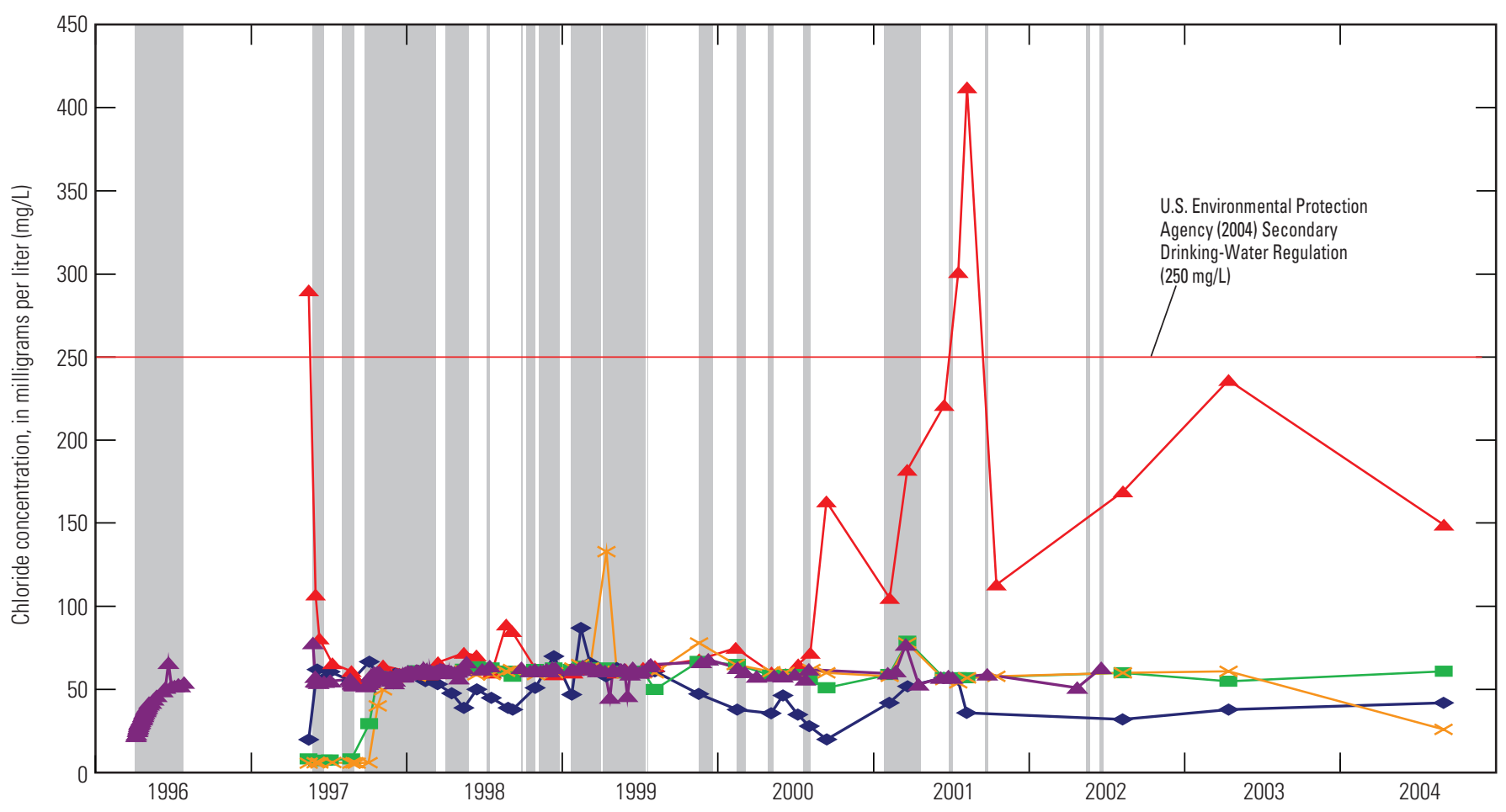

EXPLANATION

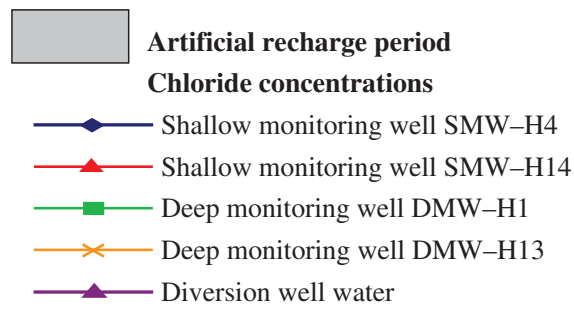

Figure 24. Chloride concentrations in ground-water samples from diversion well at Halstead diversion site and monitoring wells at Halstead recharge, May 1997-December 2004.

geochemical environment related to the injection of recharge water.

The method by which the aquifer is recharged is particularly important with respect to dissolved iron concentrations in the water. Iron in the diversion well water will react with oxygen as evidenced by the precipitation of ferric oxyhydroxides in the spreading basins and trench at the Halstead recharge site. Iron-oxidizing bacteria also could thrive under these conditions and create biofilms that can reduce permeability in well screens or aquifer material. The water from the diversion well contains little oxygen. If it is directly injected through a well, it may have little contact with atmospheric oxygen, and the iron in the recharge water would have little opportunity to oxidize. However, problems could occur if the receiving aquifer water contains oxygen and the injection well provides a source of reduced iron. Diversion well water introduced through spreading basins and trenches becomes oxygenated and then mineral precipitation occurs, possibly mediated by iron-oxidizing bacteria. Mineral precipitation and biofouling eventually could decrease the efficiency of artificial recharge by spreading basins and trenches. In addition, oxygenated water could react in the aquifer by mixing with ground water with large iron concentrations or by direct reaction with reduced iron in the aquifer material.

\section{Geochemical Simulations}

Saturation indices were calculated for water samples from all the monitoring wells at the Halstead recharge site collected during May 1997, May 1998, June 2001, August 2002, and April 2003 (table 4). Artificial recharge activities began at the Halstead recharge site on May 15, 1997; therefore, May 13, 1997, samples are considered pre-recharge samples. The August 2002 and April 2003 samples were collected after the end of the artificial recharge demonstration project and are representative of post-recharge conditions. 


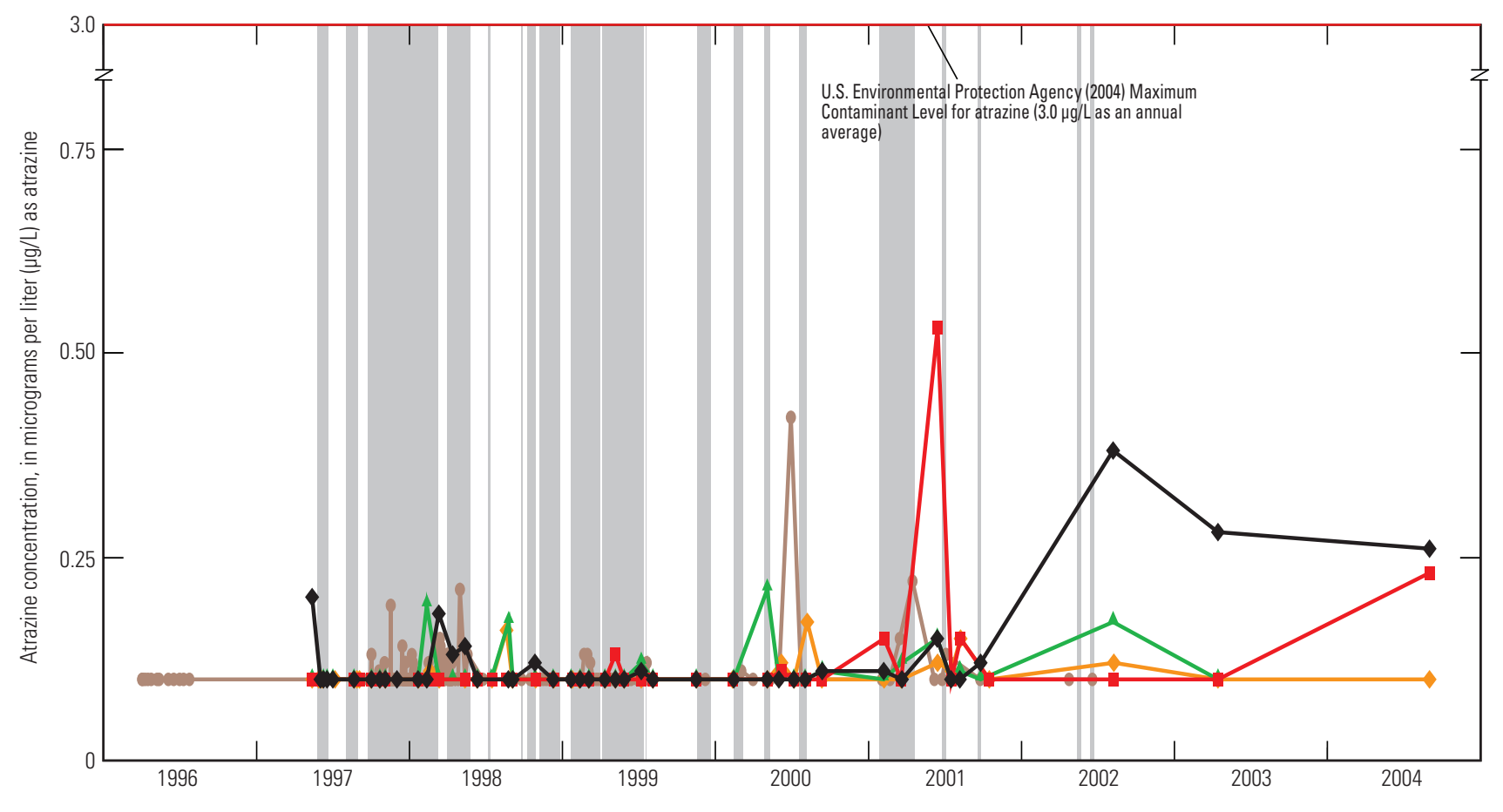

EXPLANATION

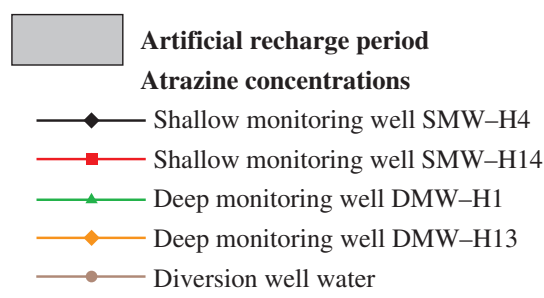

Figure 25. Atrazine concentrations in ground-water samples from diversion well at Halstead diversion site and monitoring wells at Halstead recharge site compared to concentrations in diverted recharge water, May 1997-December 2004.

Saturation indices for calcite in diversion well water samples were negative (-0.15 to -0.80$)$ indicating undersaturation with respect to calcite. Saturation indices for calcite and dolomite in shallow monitoring wells SMW-H4 and SMWH14 were undersaturated throughout the entire study period. Saturation indices increased after artificial recharge began but remained negative. Saturation indices for initial samples indicated undersaturation with respect to calcite and dolomite in deep monitoring wells DMW-H1 (-1.12 and -2.80) and DMW-H13 (-0.65 and -2.01). Saturation indices increased in samples from the deep monitoring wells after injection recharge began, and some saturation indices approached equilibrium; the May 1998 sample was at or near equilibrium with respect to calcite. The initial undersaturation with respect to calcite and dolomite in samples from all wells probably indicates limited carbonate minerals in aquifer sediments; thus, the increase in saturation indices probably is related to changes in water chemistry caused by the mixing of aquifer water with recharge water rather than dissolution of carbonate minerals.

Iron was measurable in one water sample from the shallow monitoring wells and all of the samples from the deep monitoring wells. All saturation indices calculated for these samples indicated supersaturation and the potential for amorphous ferric oxyhydroxide precipitation. Precipitation of amorphous ferric oxyhydroxides is expected to be limited unless oxygen is introduced to the water. Iron oxyhydroxide precipitates on the recharge basin and trench floors at the Halstead recharge site demonstrate that diversion well water, when in contact with oxygen, will precipitate ferric oxyhydroxides.

\section{Geochemical Effects of Artificial Recharge at Sedgwick Recharge Site}

Recharge water at the Sedgwick recharge site was diverted directly from the Little Arkansas River, treated to reduce turbidity and organic compounds, then artificially recharged through surface-spreading recharge basins (fig. 5). The major ion composition of water sampled from the two shallow and two deep monitoring wells on the site as well as 


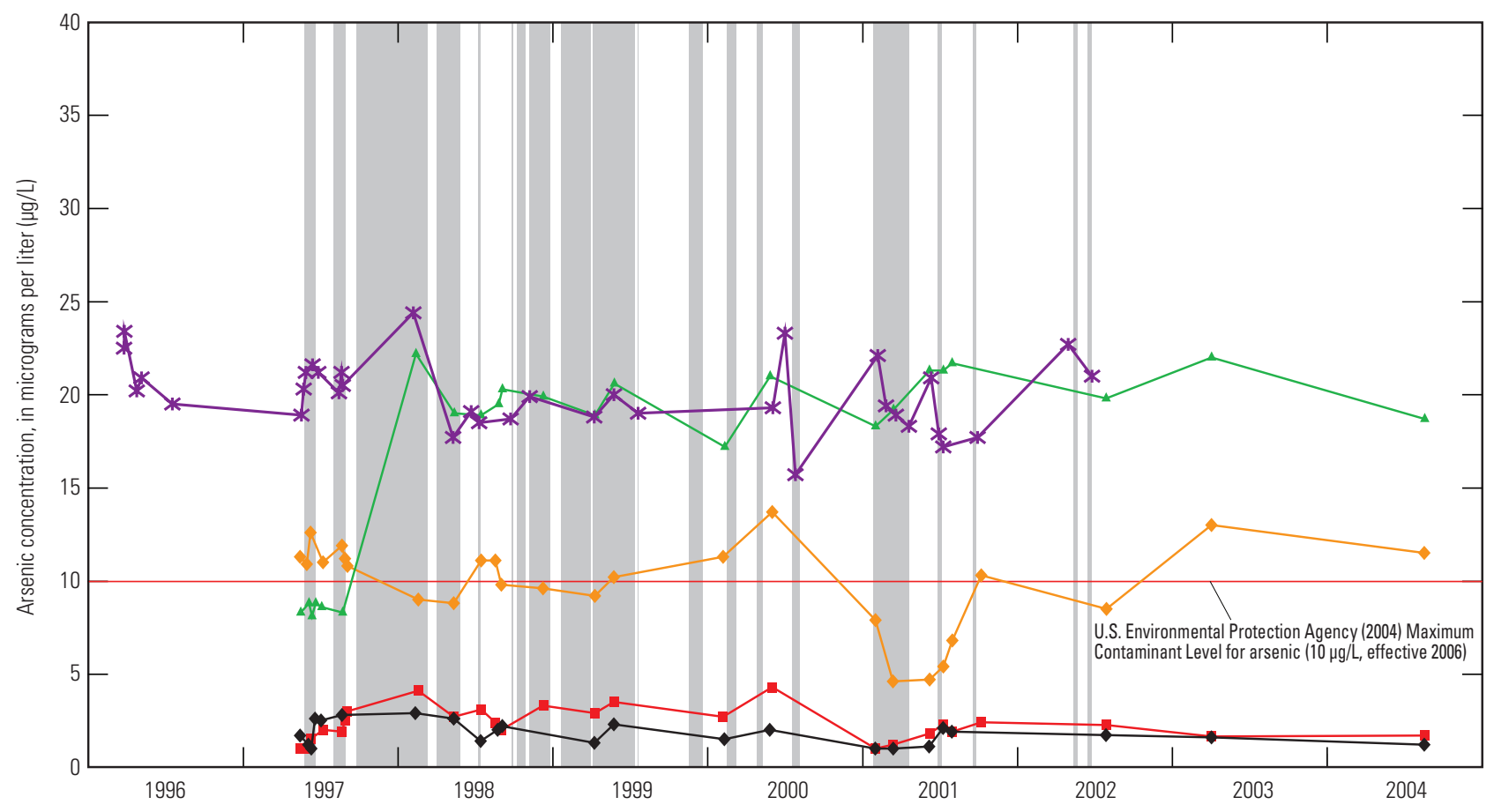

\section{EXPLANATION}

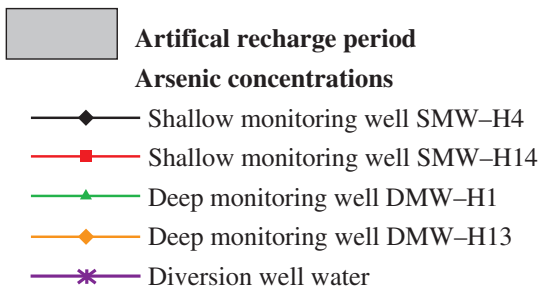

Figure 26. Arsenic concentrations in ground-water samples from diversion well at Halstead diversion site and monitoring wells at Halstead recharge site compared to concentrations in diverted recharge water, May 1997-December 2004.

the treated recharge water was analyzed using Piper diagrams to access the geochemical effects of artificial recharge at this site. Additionally, atrazine, arsenic, and iron concentrations were examined to determine effects of artificial recharge. Saturation indices calculated with respect to calcite, dolomite, and amorphous iron oxide also were examined. Simulations to model injection of treated stream water into the Equus Beds aquifer also were conducted.

\section{Major Ion Chemistry and Tracers of Recharge Water}

Piper diagrams were constructed using major ion chemistry to compare major ion concentrations during artificial recharge activities in water sampled from all monitoring wells at the Sedgwick recharge site, the treated diverted stream water, and the Little Arkansas River. Piper diagrams were constructed using data from July 1997 (fig. 28A), representing water chemistry before recharge; May 1999 (fig. 28B), representing water chemistry during recharge; and August 2002 (fig. 28C), representing the water chemistry after recharge. Piper diagrams show that water samples from the shallow monitoring wells at the Sedgwick recharge site increase in chloride proportion during artificial recharge and then revert to low chloride water types after the end of artificial recharge activities. Water samples from the deep monitoring wells show little variation in the proportions of major cations and anions.

Chloride concentrations in water samples collected from the Little Arkansas River near Sedgwick were variable and ranged from 5 to $305 \mathrm{mg} / \mathrm{L}$ with a median concentration of $70 \mathrm{mg} / \mathrm{L}$ (fig. 29A). Measured chloride concentrations exceeded the USEPA SDWR of $250 \mathrm{mg} / \mathrm{L}$ (U.S. Environmental Protection Agency, 2004) in 2 of 135 samples from 1995 through 2004. Chloride concentrations were estimated for the Little Arkansas River near Sedgwick using the regression model:

$$
C l=-112+0.203 S C+25.7 \log _{10} Q,
$$

where $\mathrm{Cl}$ is chloride concentration in milligrams per liter, $S C$ equal specific conductance in microsiemens per centimeter at 25 degrees Celsius, and $Q$ equals streamflow in cubic feet per 


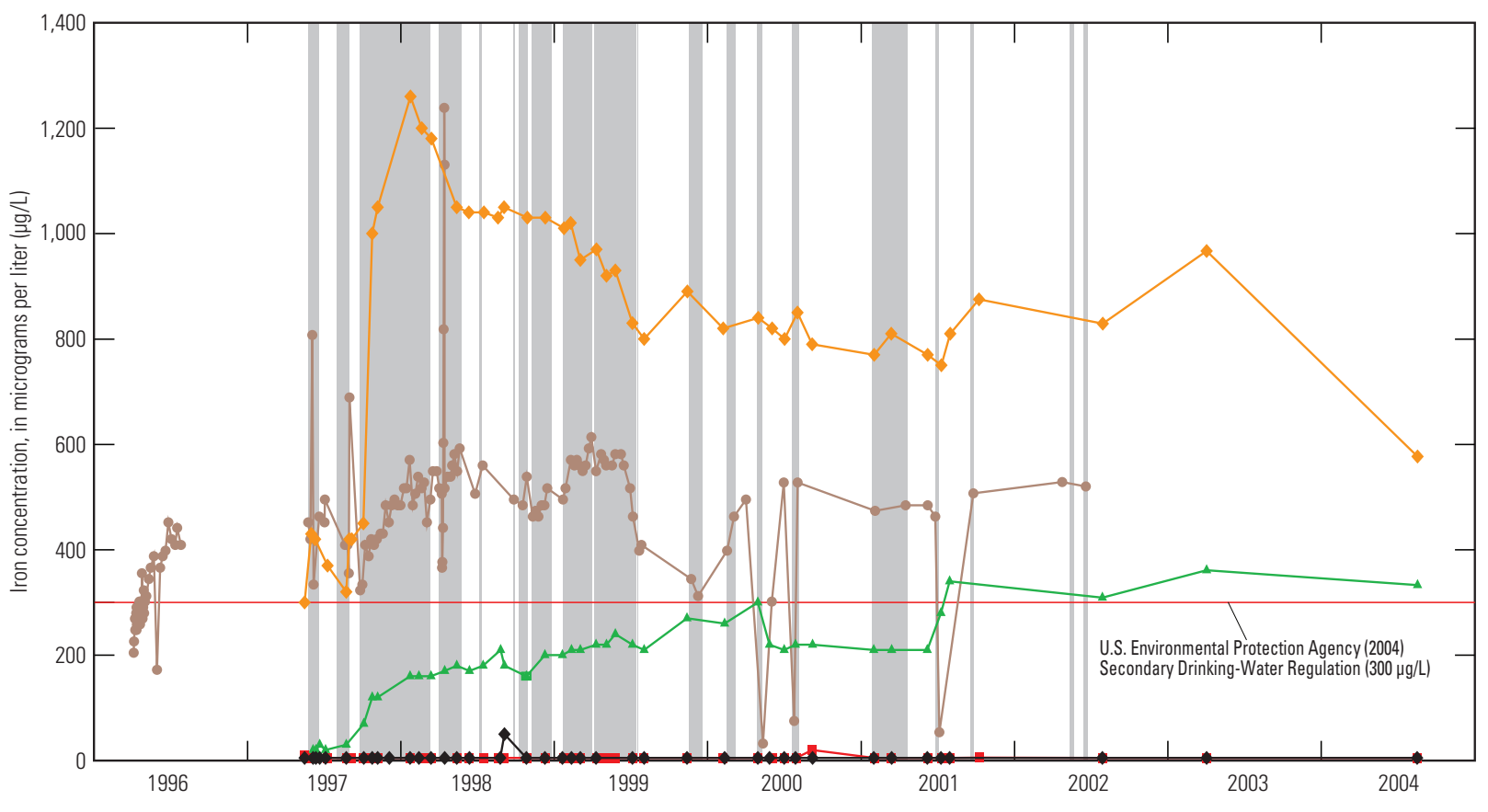

EXPLANATION

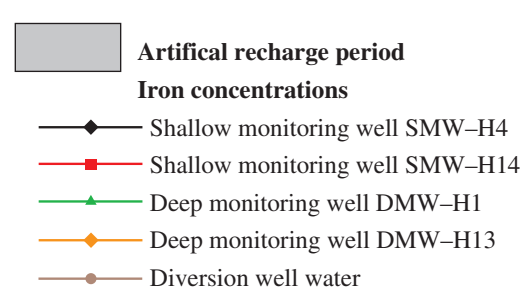

Figure 27. Iron concentrations in ground-water samples from diversion well at Halstead diversion site and monitoring wells at the Halstead recharge site compared to concentrations in diverted recharge water, May 1997-December 2004.

second. The regression has an $\mathrm{R}^{2}$ of 0.94 (Christensen and others, 2003).

Chloride concentrations in the Little Arkansas River near Sedgwick estimated from the regression with specific conductance exceeded the SDWR one time from 1999 through 2004, and the median value was $99 \mathrm{mg} / \mathrm{L}$ (data available on the Web at http://ks.water.usgs.gov/Kansas/rtqw/, accessed December 2006). Chloride concentrations in samples of treated diverted stream water were similar to concentrations found in samples from the stream because treatment did not affect chloride concentrations. Chloride concentrations in treated diverted stream water ranged from 13 to $220 \mathrm{mg} / \mathrm{L}$ with a median concentration of $62 \mathrm{mg} / \mathrm{L}$ (fig. 29). Chloride concentrations in the treated diverted stream water did not exceed the drinkingwater criterion for chloride. However, chloride concentrations in the stream may have exceeded the SDWR of $250 \mathrm{mg} / \mathrm{L}$ between samplings of the treated diverted stream water, and it would be expected that chloride concentrations in the treated diverted stream water also would exceed the SDWR at these times.

Chloride concentrations in water sampled from the deep monitoring wells were larger than concentrations in water sampled from shallow monitoring wells before artificial recharge began at the Sedgwick recharge site in April 1998. Median chloride concentrations in the monitoring wells were $12 \mathrm{mg} / \mathrm{L}$ in well SMW-S11, $11 \mathrm{mg} / \mathrm{L}$ in well SMW-S13, $64 \mathrm{mg} / \mathrm{L}$ in well DMW-S10, and $46 \mathrm{mg} / \mathrm{L}$ in well DMWS14. Chloride concentrations in the shallow monitoring wells were variable during recharge activities (April 1998 through November 2000), ranging from 12 to $156 \mathrm{mg} / \mathrm{L}$. Generally, when large chloride concentrations were detected in samples of treated diverted stream water, large chloride concentrations were detected in the samples from the shallow monitoring wells. Chloride concentrations in the shallow monitoring wells were less than the treated diverted stream water because of mixing with the existing shallow ground water. Chloride concentrations in the shallow monitoring wells never exceeded USEPA SDWR of $250 \mathrm{mg} / \mathrm{L}$ (U.S. Environmental Protection Agency, 2004) during the study period (fig. 29B).

Chloride concentrations in deep monitoring well DMWS10 ranged from 56 to $70 \mathrm{mg} / \mathrm{L}$ with a median concentration of $63 \mathrm{mg} / \mathrm{L}$ and remained relatively stable throughout the demonstration project. Chloride concentrations in monitoring well DMW-S14 ranged from 19 to $52 \mathrm{mg} / \mathrm{L}$ with a median concentration of $23 \mathrm{mg} / \mathrm{L}$. Chloride concentrations in this well decreased after artificial recharge activities began, which may 
Table 4. Saturation indices calculated for ground-water samples collected from monitoring wells at Halstead recharge site and Halstead diversion well, south-central Kansas, May 1997-April 2003.

$[--$, not calculated]

\begin{tabular}{|c|c|c|c|}
\hline \multirow[b]{2}{*}{ Date of sample } & \multicolumn{3}{|c|}{ Mineral (chemical formula) saturation indices } \\
\hline & $\begin{array}{l}\text { Calcite } \\
\left(\mathrm{CaCO}_{3}\right)\end{array}$ & $\begin{array}{c}\text { Dolomite } \\
\left(\mathrm{CaMg}\left(\mathrm{CO}_{3}\right)_{2}\right)\end{array}$ & $\begin{array}{c}\text { Amorphous iron } \\
\left(\mathrm{Fe}(\mathrm{OH})_{3}(\mathrm{a})\right)\end{array}$ \\
\hline \multicolumn{4}{|c|}{ Shallow monitoring well SMW-H4 (fig. 2B) } \\
\hline May 1997 & -2.10 & -4.79 & -- \\
\hline May 1998 & -.40 & -1.41 & -- \\
\hline June 2001 & -.99 & -2.43 & -- \\
\hline August 2002 & -1.22 & -2.88 & -- \\
\hline April 2003 & -1.04 & -2.54 & -- \\
\hline \multicolumn{4}{|c|}{ Shallow monitoring well SMW-H14 (fig. 2B) } \\
\hline May 1997 & -.93 & -2.46 & 0.89 \\
\hline May 1998 & -.47 & -1.58 & -- \\
\hline June 2001 & -.51 & -1.58 & -- \\
\hline August 2002 & -.67 & -1.90 & -- \\
\hline April 2003 & -.46 & -1.50 & -- \\
\hline \multicolumn{4}{|c|}{ Deep monitoring well DMW-H1 (fig. 2B) } \\
\hline May 1997 & -1.12 & -2.80 & .71 \\
\hline May 1998 & 0 & -.60 & 2.50 \\
\hline June 2001 & -.27 & -1.14 & 2.43 \\
\hline August 2002 & -.28 & -1.15 & 2.51 \\
\hline April 2003 & -.11 & -.81 & 2.75 \\
\hline \multicolumn{4}{|c|}{ Deep monitoring well DMW-H13 (fig. 2B) } \\
\hline May 1997 & -.65 & -2.01 & 2.63 \\
\hline May 1998 & -.03 & -.73 & 3.25 \\
\hline June 2001 & .01 & -.59 & 2.73 \\
\hline August 2002 & -.26 & -1.14 & 2.98 \\
\hline April 2003 & -.09 & -.80 & 3.17 \\
\hline \multicolumn{4}{|c|}{ Diversion well (fig. 2) } \\
\hline May 1997 & -.80 & -- & -.42 \\
\hline May 1998 & -.35 & -- & -.87 \\
\hline June 2001 & -.15 & -- & 1.42 \\
\hline
\end{tabular}

indicate the displacement of deep aquifer water with water from the shallow part of the aquifer.

Atrazine concentrations in the Little Arkansas River near Sedgwick ranged from 0.10 to $41 \mu \mathrm{g} / \mathrm{L}$ with an average concentration of $4.0 \mu \mathrm{g} / \mathrm{L}$ (fig. 30A), which exceeds the USEPA MCL of $3.0 \mu \mathrm{g} / \mathrm{L}$ as an annual average. The regression model is:

$$
\begin{gathered}
\log _{10} \text { atrazine }=0.237-0.745 \cos \left(\frac{2 \pi D}{365}\right)+ \\
0.504 \sin \left(\frac{2 \pi D}{365}\right)-0.000647 S C,
\end{gathered}
$$

where atrazine is in micrograms per liter, $D$ is the julian day of the year, and $S C$ is specific conductance in microsiemens per centimeter at 25 degrees Celsius. The regression has an $\mathrm{R}^{2}$ of 0.60 (Christensen and others (2000, 2003).

Annual averages calculated from estimated daily atrazine concentrations developed for the Sedgwick recharge site (fig. 30A) from 1999 through 2004 did not exceed the drinking-water criterion. Measured atrazine concentrations in the treated diverted stream water ranged from 0.10 to $6.8 \mu \mathrm{g} / \mathrm{L}$ with an average concentration of $0.30 \mu \mathrm{g} / \mathrm{L}$ (fig. $30 \mathrm{~B}$ ). The maximum concentration of $6.8 \mu \mathrm{g} / \mathrm{L}$ occurred on a day when the PAC treatment malfunctioned (Jerry Blain, Water Supply Projects Administrator, city of Wichita, Water and Sewer Department, written commun., August 2005), demonstrating 


\section{(A) July 1997}

\section{EXPLANATION}

A Monitoring well SMW-S11

$\nabla$ Monitoring well SMW-S13

- Monitoring well DMW-S10

- Monitoring well DMW-S14

+ Treated diverted stream water

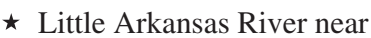
Sedgwick

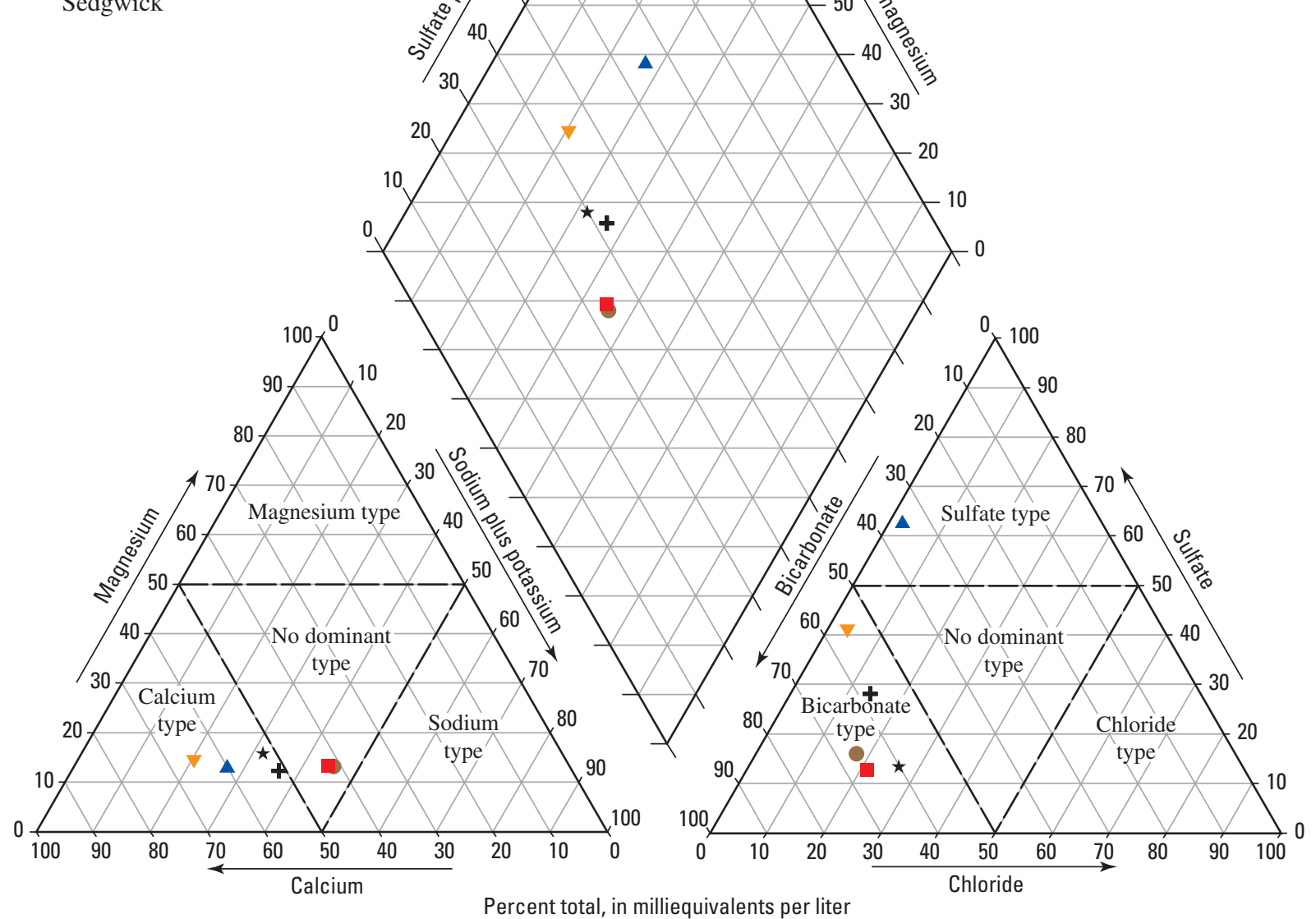

Figure 28. Major ion chemistry in water samples from the Sedgwick recharge site in (A) July 1997, (B) May 1999, and (C) August 2002.

the need for treatment of diverted stream water for atrazine removal. The average atrazine concentration in shallow monitoring well SMW-S11 before artificial recharge began was $0.17 \mu \mathrm{g} / \mathrm{L}$. This well was the only monitoring well where atrazine was detected before artificial recharge began in April 1998. Atrazine concentrations increased in water samples from both shallow monitoring wells after artificial recharge began at the Sedgwick recharge site. The maximum concentration of $1.1 \mu \mathrm{g} / \mathrm{L}$ occurred in a sample from well SMW-S11 in August 1998. Generally larger concentrations of atrazine in the shallow monitoring wells were observed when large concentrations occurred in the treated diverted stream water (fig. 30B). Atrazine concentrations in the treated diverted stream water exceeded USEPA MCL of $3.0 \mu \mathrm{g} / \mathrm{L}$ for drinking water in three discrete samples. However, the annual average concentration in water from the shallow monitoring wells was considerably less than $3.0 \mu \mathrm{g} / \mathrm{L}$. Atrazine was not detected in water samples from the deep monitoring wells at this site.

The increase in chloride and atrazine concentrations in water from the shallow wells after recharge began at the Sedgwick site indicates the presence of treated diverted stream water in the shallow parts of the aquifer; however, the minimal change in the chloride concentrations in water sampled from the deep monitoring wells indicates that the treated diverted stream water did not reach the deeper parts of the aquifer at the Sedgwick recharge site. 


\section{(B) May 1999}

\section{EXPLANATION}

- Monitoring well SMW-S11

$\checkmark$ Monitoring well SMW-S13

- Monitoring well DMW-S10

- Monitoring well DMW-S14

+ Treated diverted stream water

$\star$ Little Arkansas River near Sedgwick

r

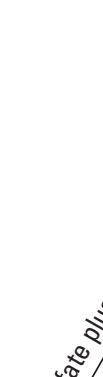

100

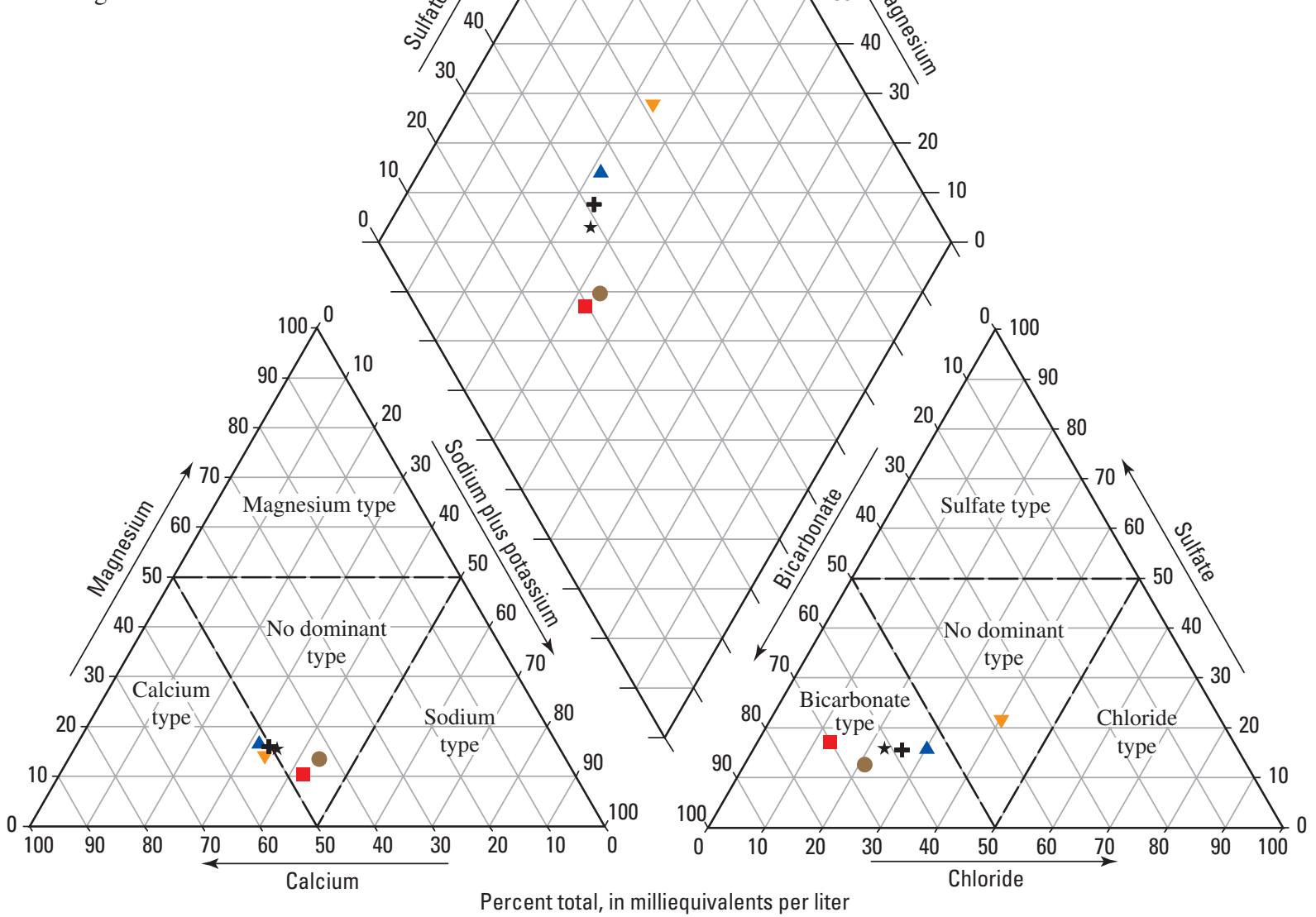

Figure 28. Major ion chemistry in water samples from the Sedgwick recharge site in (A) July 1997, (B) May 1999, and (C) August 2002-Continued.

\section{Selected Trace Metal Chemistry}

At the Sedgwick recharge site, concentrations of arsenic in samples from the treated diverted stream water ranged from 2.1 to $5.9 \mu \mathrm{g} / \mathrm{L}$. The larger concentrations in this range usually corresponded with larger concentrations in water from the Little Arkansas River near Sedgwick, which ranged from 1.1 to $14 \mu \mathrm{g} / \mathrm{L}$. Arsenic concentrations were less than $5.0 \mu \mathrm{g} / \mathrm{L}$ in all water samples from the monitoring wells at the Sedgwick recharge site. However, arsenic concentrations were slightly larger in samples from the deep monitoring wells, ranging from 1.8 to $5.0 \mu \mathrm{g} / \mathrm{L}$, than in the shallow monitoring wells, ranging from less than 1.0 to $2.7 \mu \mathrm{g} / \mathrm{L}$ (fig. 31). The concentrations in all monitoring wells and treated diverted stream water were less than the USEPA MCL of $10 \mu \mathrm{g} / \mathrm{L}$. Arsenic concentrations in ground water did not change substantially during recharge operations, indicating that, if arsenic is present in aquifer material at this site, the artificial recharge process did not mobilize arsenic.

With the exception of a few large concentrations in water samples from monitoring well SMW-S11, dissolved iron concentrations in water samples from all monitoring wells at the Sedgwick recharge monitoring site were small, if detected at all (fig. 32B). Dissolved oxygen concentrations in well SMW-S11 ranged from 3.1 to $6.8 \mathrm{mg} / \mathrm{L}$ in the water samples with the large iron concentrations. These concentrations indicate that the source of the iron is not the aquifer water in the vicinity of well SMW-S11 because dissolved 


\section{(C) August 2002}

\section{EXPLANATION}

A Monitoring well SMW-S11

$\checkmark$ Monitoring well SMW-S13

- Monitoring well DMW-S10

- Monitoring well DMW-S14

+ Treated diverted stream water

$\star$ Little Arkansas River near Sedgwick

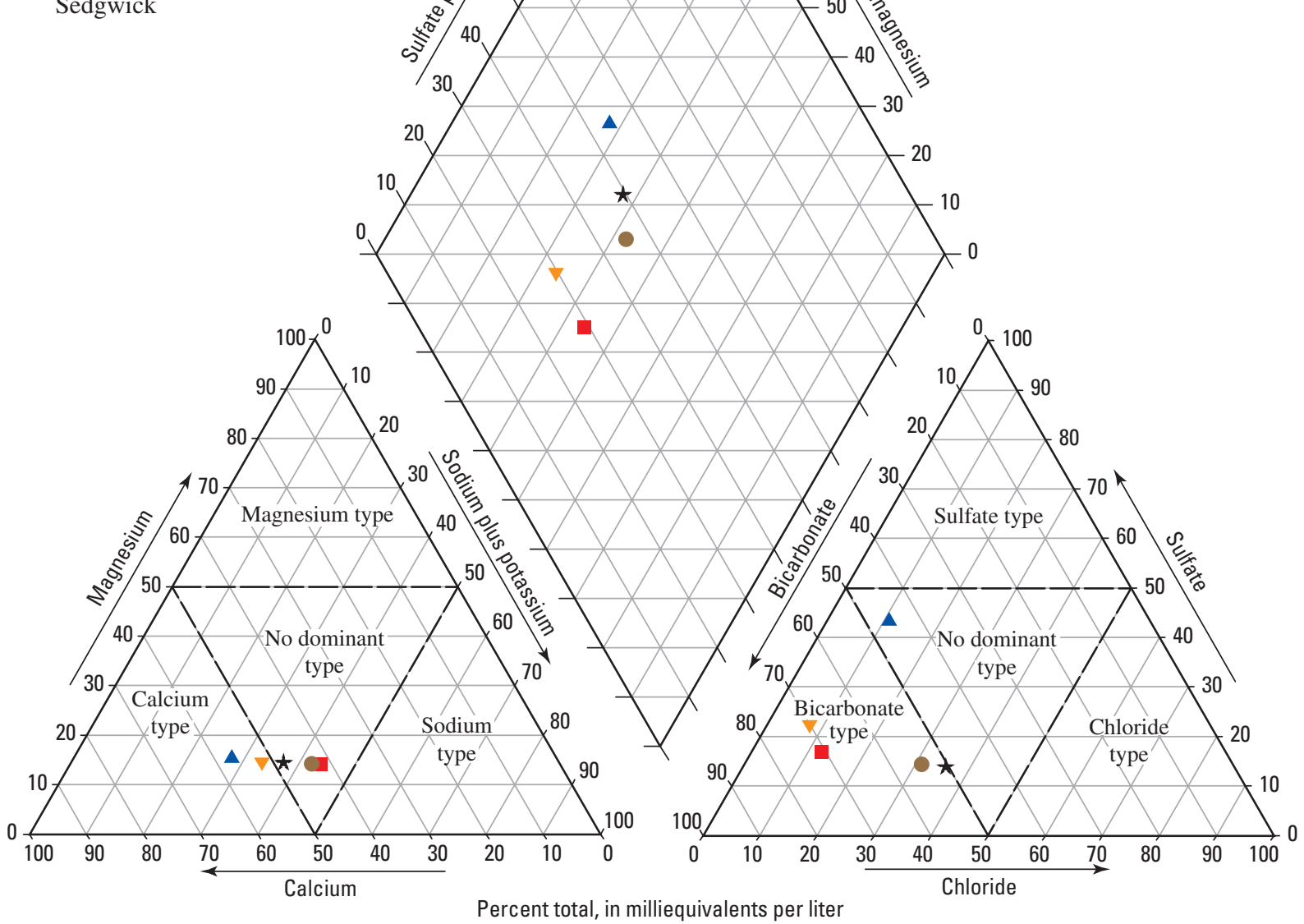

Figure 28. Major ion chemistry in water samples from the Sedgwick recharge site in (A) July 1997, (B) May 1999, and (C) August 2002-Continued.

iron likely would be oxidized and precipitate in the presence of large dissolved oxygen concentrations. The large iron concentrations initially detected in water from the well could be an artifact of insufficient well development. The development of wells before water-quality sampling is necessary to remove the loose sediment in the well that may have been introduced during drilling. Metals, such as iron, can be associated with the sediment that could have been disturbed during well installation. Field notes recorded during the first several samplings at this well indicated large sediment concentrations in the water from well.

\section{Geochemical Simulations}

Saturation indices were simulated for water samples collected during July 1997, May 1999, June 2000, and June 2001 for all monitoring wells at the Sedgwick recharge site as well as the treated diverted stream water (table 5). Artificial recharge activities began at the Sedgwick recharge site in April 1998; therefore, the samples collected during July 1997 were considered representative of pre-recharge conditions.

Calcite and dolomite saturation indices in the treated diverted stream water ranged from -0.54 to 0.21 and from -1.26 to 0 , respectively. For initial water samples from the 


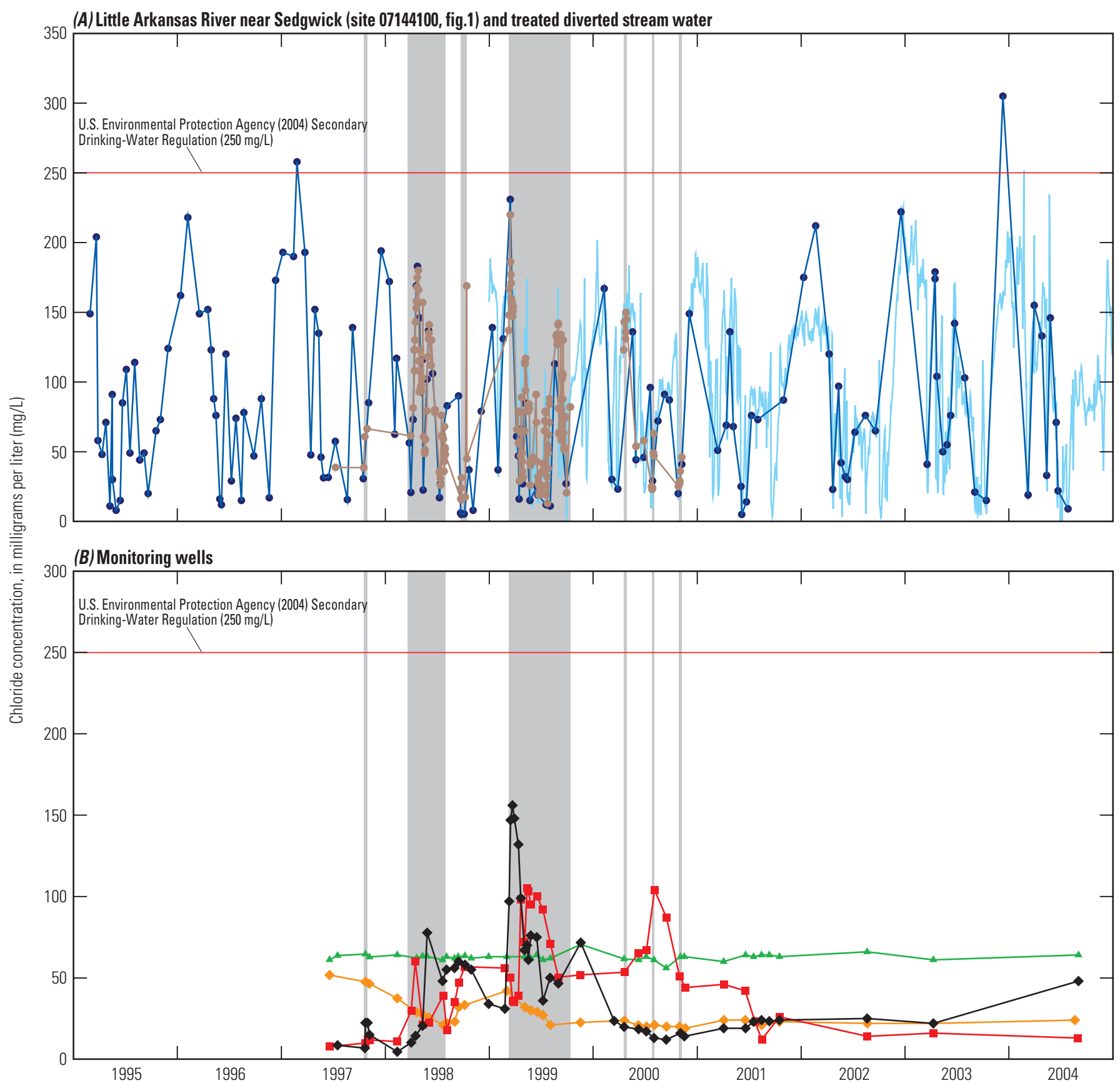

EXPLANATION

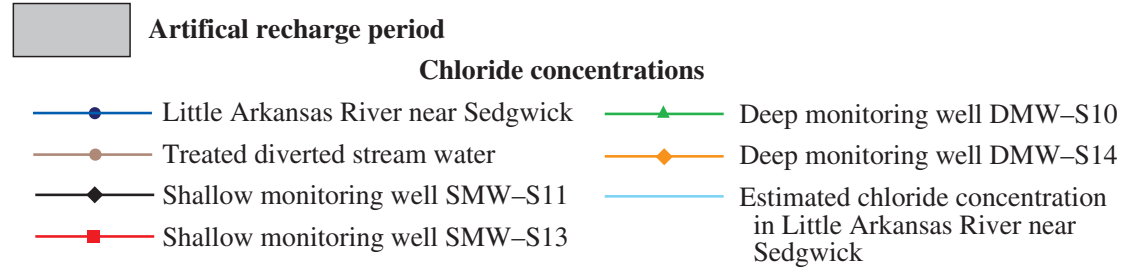

Figure 29. Measured and estimated chloride concentrations in water samples from (A) Little Arkansas River near Sedgwick (site 07144100, fig. 1), treated diverted stream water, and (B) monitoring wells at the Sedgwick recharge site, February 1995December 2004. 


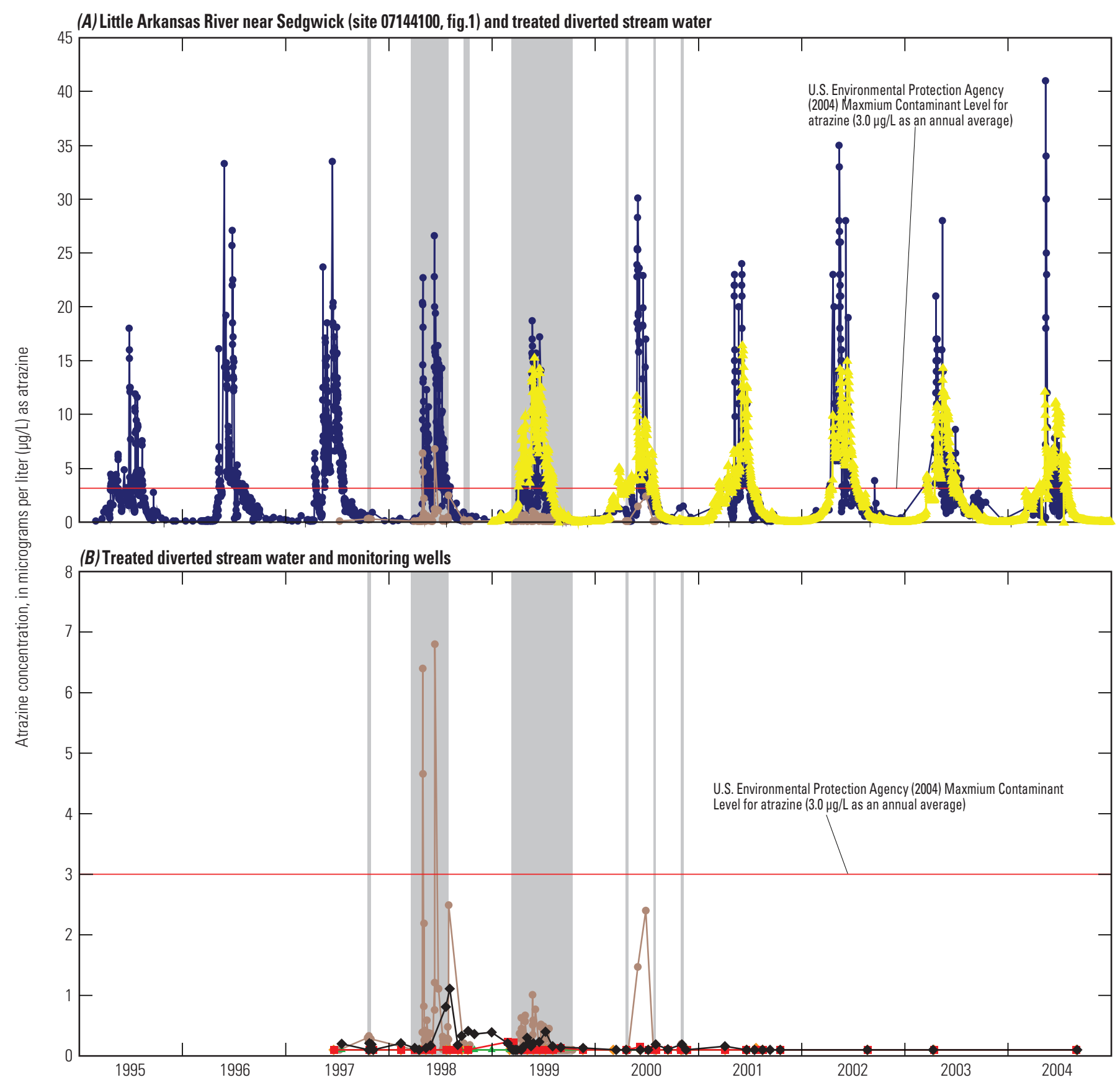

\section{EXPLANATION}

Artificial recharge period

\section{Atrazine concentrations}

$\begin{array}{ll}\longrightarrow \text { Little Arkansas River near Sedgwick } & \text { Deep monitoring well DMW-S10 } \\ \longrightarrow \text { Treated diverted stream water } & \text { Deep monitoring well DMW-S14 } \\ \longrightarrow \text { Shallow monitoring well SMW-S11 } & \text { Estimated continuous atrazine } \\ \text { Shallow monitoring well SMW-S13 } & \text { contrations from Little Arkansas } \\ & \text { River near Sedgwick }\end{array}$

Figure 30. Atrazine concentrations in water samples from (A) Little Arkansas River near Sedgwick, treated diverted stream water, and $(B)$ monitoring wells at the Sedgwick recharge site, February 1995-December 2004. 
shallow monitoring wells, saturation indices for calcite $(-0.46$ and -0.81$)$ and dolomite $(-1.6$ and -2.27$)$ indicated undersaturation. Saturation indices for samples collected from shallow wells during and after artificial recharge also indicated undersaturation, except for one near-zero saturation index for calcite in water from well SMW-S11. Calcite saturation indices indicated slight undersaturation in water sampled from deep monitoring wells DMW-S10 and DMW-S14, whereas dolomite saturation indices indicated undersaturation. The saturation indices for the few samples in which iron was measurable indicated supersaturation with respect to amorphous ferric hydroxide.

The initial negative saturation indices for calcite and dolomite for samples from the shallow monitoring wells indicate that carbonate minerals probably are not present in the shallow aquifer. Similarly dolomite is probably not present in the deeper aquifer, but calcite may be reacting in the deeper aquifer to produce saturation indices that approach equilibrium.
The saturation index for calcite is greater than zero for at least one sample of the treated diverted stream water, which indicates the potential for calcite precipitation. The introduction of oxygen with the treated diverted stream water combined with saturation indices in the aquifer that indicate supersaturation with respect to amorphous ferric hydroxide indicate the possibility of precipitation of ferric oxyhydroxides.

Simulations to model injection of treated stream water into the Equus Beds aquifer were conducted using PHREEQC. The stream water is oxygenated, which when injected into ground water with low dissolved oxygen concentrations, could result in alterations in the redox condition of the ground water. Direct injection of stream water was not tested during the demonstration phase of the Equus Beds Ground-Water Recharge Project. The model simulates mixing the treated stream water from the Sedgwick site (median concentrations) with pre-recharge ground water from deep monitoring well DMW-H13 at the Halstead site.

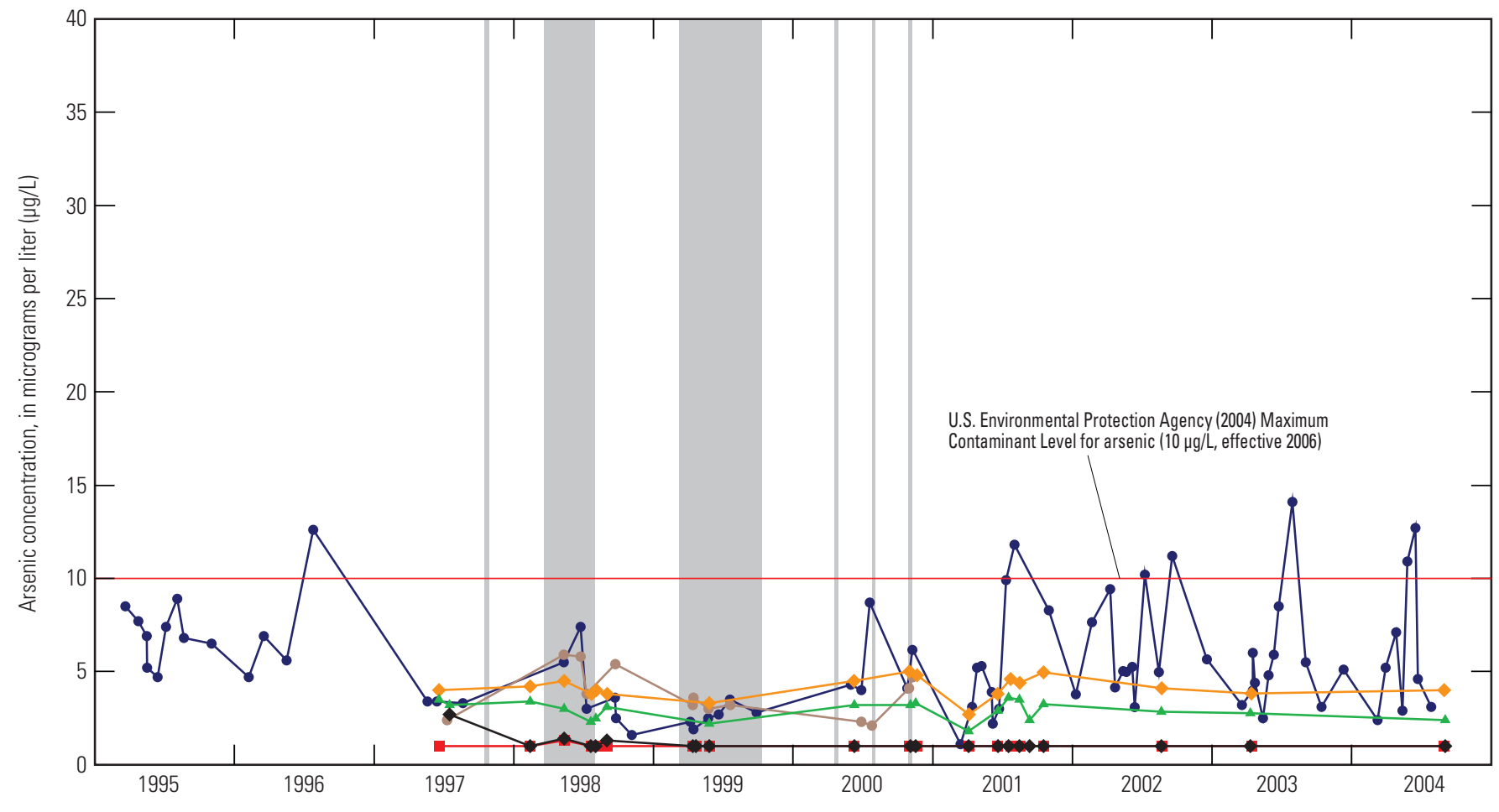

\section{EXPLANATION}

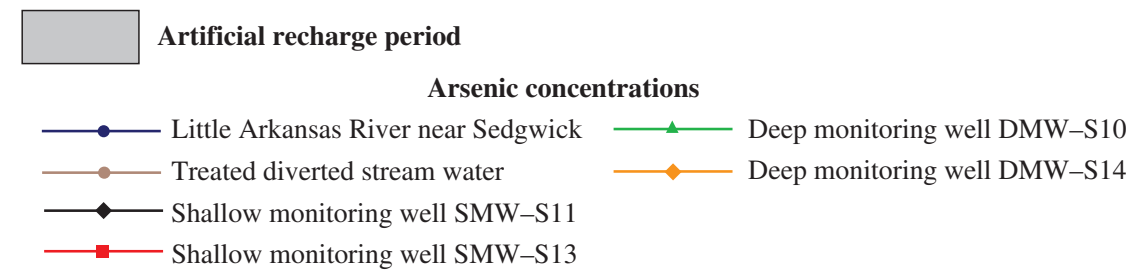

Figure 31. Arsenic concentrations in water samples from Little Arkansas River near Sedgwick, treated diverted stream water, and monitoring wells at the Sedgwick recharge site, February 1995-December 2004. 


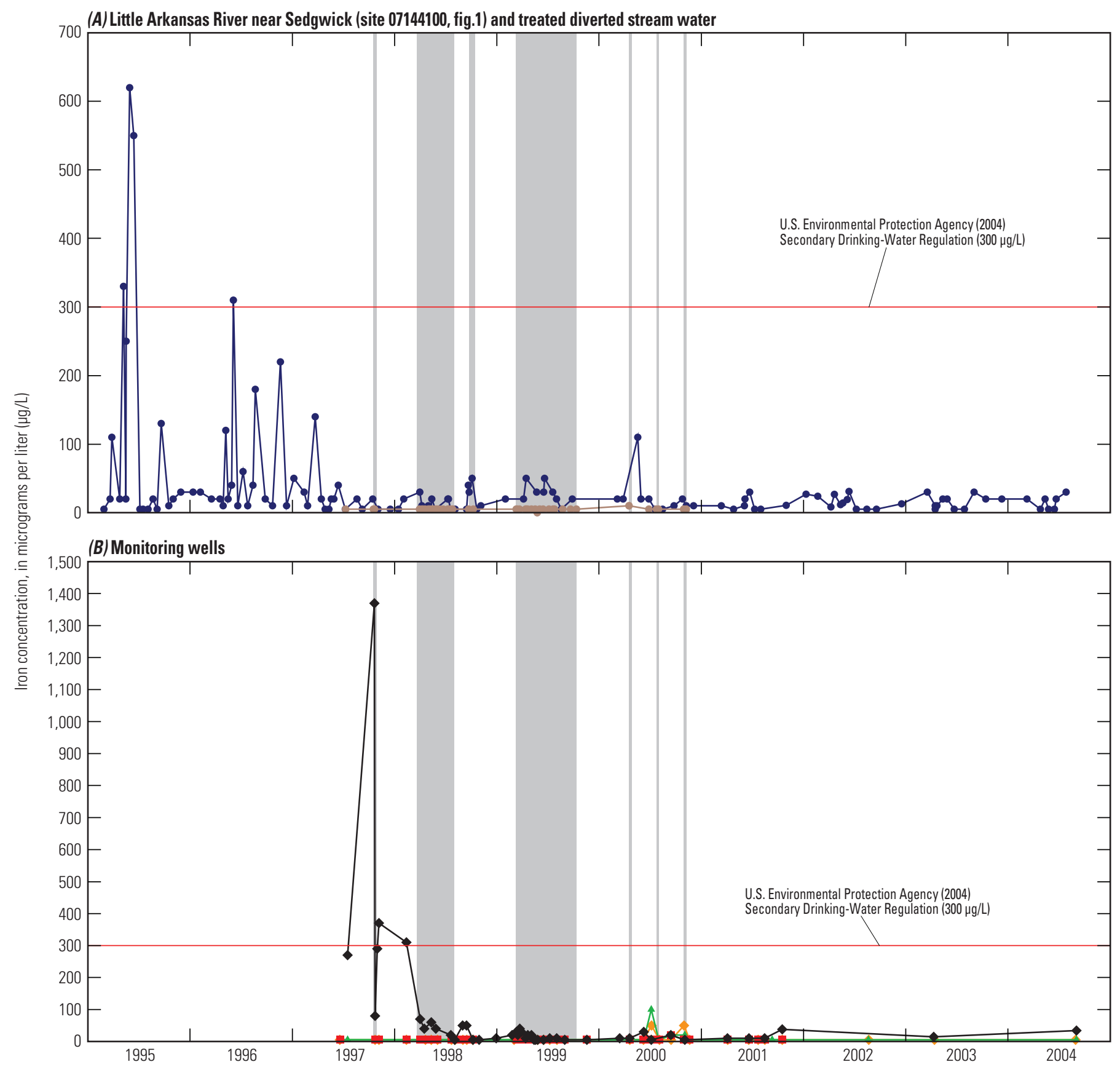

EXPLANATION

Artificial recharge period

Iron concentrations

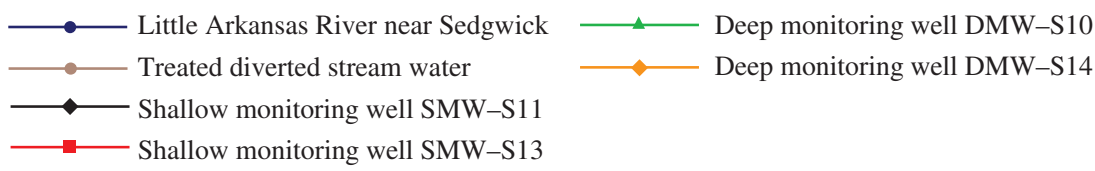

Figure 32. Iron concentrations in water samples from $(A)$ Little Arkansas River near Sedgwick, treated diverted stream water, and $(B)$ monitoring wells at the Sedgwick recharge site, February 1995-December 2004. 
Results of the simulation indicate that calcite oversaturation is likely only in mixtures that are greater than 90 percent treated recharge water from the Little Arkansas River (fig. 33). The treated stream water is oversaturated with respect to calcite, the receiving ground water is undersaturated with respect to calcite, and the calculations indicate it is possible that calcite precipitation may occur. Calcite precipitation could reduce permeability and reduce effectiveness of artificial recharge.

Amorphous iron oxyhyrdoxide may precipitate as oxygenated treated stream water is injected into the ground water, which has small dissolved oxygen concentrations and an average dissolved iron concentration of $845 \mu \mathrm{g} / \mathrm{L}$. Calculations indicate oversaturation for all mixtures of the two waters (fig. 33). In addition, iron bacteria could be a cause for concern for injection of oxygenated water into the aquifer. It is possible that biofouling of the injection well could occur causing increased precipitation of iron and creation of a biofilm associated with iron bacteria activity (Hem, 1992). The precipitation and biofouling could decrease the efficiency of the injection well as well as reduce the permeability of the aquifer material in vicinity of the well.

Table 5. Saturation indices calculated for ground-water samples collected from monitoring wells at Sedgwick recharge site and for samples of treated diverted stream water, south-central Kansas, July 1997-April 2003.

$[--$, not calculated $]$

\begin{tabular}{|c|c|c|c|}
\hline \multirow[b]{2}{*}{ Date of sample } & \multicolumn{3}{|c|}{ Mineral (chemical formula) saturation indices } \\
\hline & $\begin{array}{l}\text { Calcite } \\
\left(\mathrm{CaCO}_{3}\right)\end{array}$ & $\begin{array}{c}\text { Dolomite } \\
\left(\mathrm{CaMg}\left(\mathrm{CO}_{3}\right)_{2}\right)\end{array}$ & $\begin{array}{c}\text { Amorphous iron } \\
\left(\mathrm{Fe}(\mathrm{OH})_{3}(\mathrm{a})\right)\end{array}$ \\
\hline \multicolumn{4}{|c|}{ Shallow monitoring well SMW-S11 (fig. 5) } \\
\hline July 1997 & -0.46 & -1.6 & 2.58 \\
\hline May 1999 & .02 & -.47 & -- \\
\hline June 2000 & -.97 & -2.46 & 1.30 \\
\hline June 2001 & -1.27 & -3.07 & .88 \\
\hline \multicolumn{4}{|c|}{ Shallow monitoring well SMW-S13 (fig. 5) } \\
\hline July 1997 & -.81 & -2.27 & -- \\
\hline May 1999 & -1.12 & -2.79 & -- \\
\hline June 2000 & -.89 & -2.25 & -- \\
\hline June 2001 & -1.16 & -2.81 & -- \\
\hline \multicolumn{4}{|c|}{ Deep monitoring well DMW-S10 (fig. 5) } \\
\hline July 1997 & -.12 & -.74 & -- \\
\hline May 1999 & -.05 & -.60 & -- \\
\hline June 2000 & -.10 & -.66 & -- \\
\hline June 2001 & -.20 & -.90 & -- \\
\hline \multicolumn{4}{|c|}{ Deep monitoring well DMW-S14 (fig. 5) } \\
\hline July 1997 & -.14 & -.76 & -- \\
\hline May 1999 & -.09 & -.67 & -- \\
\hline June 2000 & -.19 & -.85 & -- \\
\hline June 2001 & -.18 & -.82 & -- \\
\hline \multicolumn{4}{|c|}{ Treated diverted water (collected from settling basin, fig. 5) } \\
\hline July 1997 & -.01 & -.55 & -- \\
\hline May 1999 & .21 & 0 & -- \\
\hline June 2000 & -.54 & -1.26 & -- \\
\hline June 2001 & -- & -- & -- \\
\hline
\end{tabular}




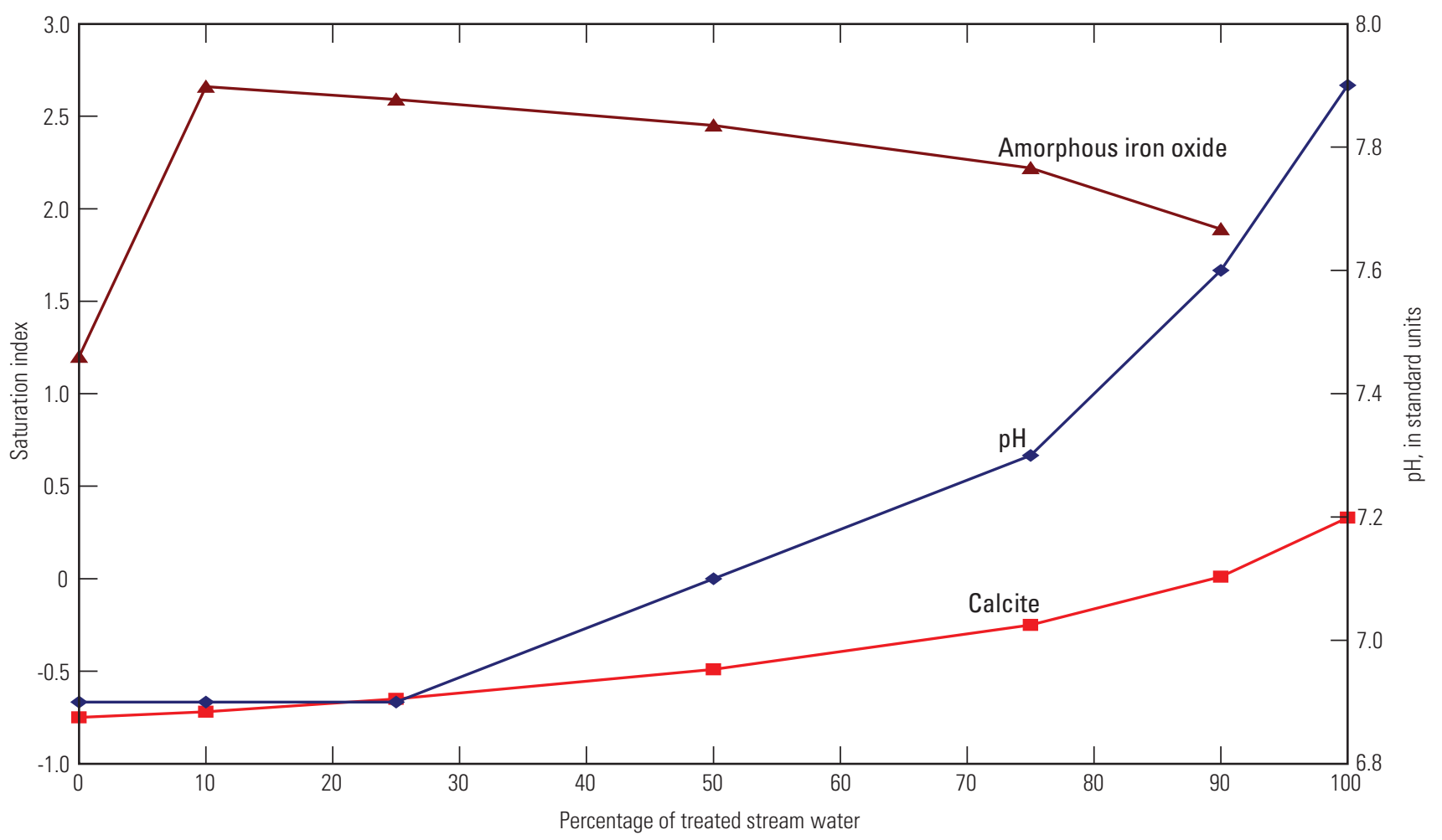

Figure 33. Saturation indices for calcite, amorphous iron oxide, and modeled $\mathrm{pH}$ for the theoretical mixing model of artificial recharge by injection of treated stream water into the Equus Beds aquifer.

\section{Summary and Conclusions}

The Wichita well field, developed in the 1940s in the Equus Beds aquifer, is one of the primary sources of water for the city of Wichita and the surrounding area in south-central Kansas. Historical water use for municipal supply and irrigation had caused water levels in the Equus Beds aquifer to decline more than $30 \mathrm{ft}$ by 1993 in some areas. Water-level declines represent a diminished amount of available water but also may accelerate migration of saltwater from the Burrton oil field to the northwest and from the Arkansas River to the southwest into the freshwater of the Equus Beds aquifer.

Artificial recharge of the Equus Beds aquifer will augment the city of Wichita's future water-supply needs and help to preserve all existing aquifer uses from degradation of the aquifer from saltwater migration by increasing water levels in the aquifer. The Equus Beds Ground-Water Recharge Project is a cooperative effort between the city of Wichita and the U.S. Geological Survey (USGS). Artificial recharge, as a part of the Equus Beds Ground-Water Recharge Demonstration Project, involved capturing flows larger than base flow from the Little Arkansas River and recharging the water to the Equus Beds aquifer by means of infiltration or injection. The project used two methods of stream-water diversion for recharge water and three methods of artificial recharge. The USGS role in the cooperative study is to document changes in historic hydrologic water-quality conditions, to identify the probable causes of the changes in the study area, and to define pre-recharge conditions for evaluating the effects of artificial recharge related to water quantity and water quality.

This report examines the geochemical effects of induced stream-water and artificial recharge activities that were a part of the Equus Beds Ground-Water Recharge Demonstration Project, which was conducted April 1995 through May 2002. Geochemical effects were determined through collection and analysis of hydrologic and water-quality data, application of statistical, mixing, flow, and solute-transport, and geochemical model simulations.

At the Halstead diversion site a pumping well in the aquifer adjacent to the stream was used to capture water for artificial recharge. Water collected at this site was pumped without treatment to the Halstead recharge site.

Estimated chloride concentrations in the Little Arkansas River at Highway 50 near Halstead exceeded the SDWR of $250 \mathrm{mg} / \mathrm{L}$ established by USEPA about 30 percent of the time. Chloride concentrations were slightly smaller than stream concentrations at shallow monitoring wells nearest the stream at the Halstead diversion well site and decreased to background concentrations ( 19 to $32 \mathrm{mg} / \mathrm{L}$ ) in shallow monitoring wells $500 \mathrm{ft}$ or more from the stream. Chloride concentrations in the deep monitoring well (EB-145-PD5) at the Halstead diversion well site increased from background concentrations of $15 \mathrm{mg} / \mathrm{L}$ to a maximum of $130 \mathrm{mg} / \mathrm{L}$ during the pumping phase of the demonstration project and decreased to about $40 \mathrm{mg} / \mathrm{L}$ after pumping ceased. Chloride concentrations in the diversion well increased from 20 to about $60 \mathrm{mg} / \mathrm{L}$ during the pumping phase of the demonstration project. 
The annual average of estimated atrazine concentrations in the Little Arkansas River at Highway 50 was equal to the $3.0 \mu \mathrm{g} / \mathrm{L}$ for 1999 and was smaller than $3.0 \mu \mathrm{g} / \mathrm{L}$ for 2000 through 2004. The USEPA MCL for atrazine is $3.0 \mu \mathrm{g} / \mathrm{L}$ as an annual average. Although atrazine concentrations diminish as the induced stream-water recharge migrates through the aquifer, the removal of atrazine is not complete. Atrazine initially was detected in samples from the diversion well 4 months after pumping began, and atrazine was detected periodically at concentrations up to $0.42 \mu \mathrm{g} / \mathrm{L}$ in the diversion well and the deep monitoring well at the diversion well site. Detections of atrazine degradation products were rare, which indicates decreases in atrazine concentration are more likely because of sorption processes than degradation.

Thirteen percent of the 54 discrete water-quality samples from the Little Arkansas River at Highway 50 near Halstead exceeded the MCL of $10 \mu \mathrm{g} / \mathrm{L}$ for arsenic. Arsenate was the dominant species in surface-water samples. Arsenic concentrations for samples from the three shallow monitoring wells nearest to the stream at the diversion well site generally were near or less than the detection limit. Naturally occurring arsenic concentrations consistently exceeded the MCL in water from shallow monitoring wells more than $500 \mathrm{ft}$ from the stream, the deep monitoring well, and the diversion well, with median concentrations ranging from 16 to $25 \mu \mathrm{g} / \mathrm{L}$. Arsenate was the dominant species in surface-water samples. Arsenic concentrations in water samples from these wells did not change in response to pumping the diversion well.

Dissolved iron concentrations observed in the Little Arkansas River at Highway 50 near Halstead generally were less than the 300- $\mu \mathrm{g} / \mathrm{L}$ SDWR established by the USEPA. The two shallow monitoring wells nearest the stream had large iron concentrations, ranging from 1,600 to $6,250 \mu \mathrm{g} / \mathrm{L}$. Iron concentrations in samples from all other wells increased in response to pumping from less than or equal to $300 \mu \mathrm{g} / \mathrm{L}$ to between 300 and $1,000 \mu \mathrm{g} / \mathrm{L}$.

Saturation indices for calcite and dolomite for water samples from the Halstead diversion site indicate that these minerals probably are not present in the aquifer adjacent to the Little Arkansas River. Saturation indices for amorphous ferric oxyhydroxide indicate the potential for precipitation of the mineral from diversion well water; however, precipitation is expected to be limited in the absence of oxygen.

Piper diagrams indicate that water sampled from the diversion well is a mixture of water from the Little Arkansas River and water in the aquifer adjacent to the stream. Water levels and chemistry indicate that the shallow part of the aquifer adjacent to the stream was constantly recharged by the Little Arkansas River and that the water chemistry of the shallow aquifer was similar to the chemistry of the Little Arkansas River. A simple chloride-based mixing model indicates that water sampled from monitoring well EB-145-A1 was about 80 percent stream water and 20 percent ground water. The estimated mixture of water sampled from the diversion well was about 25 percent water from monitoring well EB-145-A1 and about 75 percent from ground water. Using these percent- ages, an estimated 75 percent of atrazine is sorbed to aquifer sediments, decreasing the need for additional water treatment to remove atrazine before recharge. A flow and solute-transport model was developed to simulate flow of the stream water to the pumping well using water levels and chloride concentrations. Flow and transport-model simulation results indicate that at steady state - after decades - the rate of induced stream-water recharge is about 75 percent of the pumping rate.

Water captured by the diversion well was pumped to the Halstead recharge site and artificially recharged to the aquifer through surface-spreading recharge basins, a recharge trench, or a direct-injection recharge well. The water composition of the recharge (diversion well) water and water from all monitoring wells was a calcium bicarbonate type, except for shallow monitoring well SMW-H14, which contained a sodium chloride type water. The different water type is attributed to the well's proximity to a sewage treatment lagoon. After artificial recharge through the basins and trench began, chloride concentrations in water from the shallow monitoring wells approximated the chloride concentration in recharge (diversion well) water $(60 \mathrm{mg} / \mathrm{L})$. After artificial recharge through the basins and trench ended, chloride concentrations in water from shallow monitoring well SMW-H14 increased to greater than pre-recharge concentrations. The effects of artificial recharge were not evident in water from the deep monitoring wells until artificial recharge through the direct injection well began, after which chloride concentrations increased to about $60 \mathrm{mg} / \mathrm{L}$, and remained at that concentration for the duration of the study.

The average atrazine concentration in recharge (diversion well) water for the Halstead recharge site was less than $0.1 \mu \mathrm{g} / \mathrm{L}$. Atrazine concentrations in all water samples from monitoring wells were considerably less than the USEPA MCL of $3.0 \mu \mathrm{g} / \mathrm{L}$ as an annual average. After artificial recharge through the basins and trench began, atrazine concentrations in water from the shallow monitoring wells at the Halstead recharge site were similar to concentrations in the recharge water, generally $0.15 \mu \mathrm{g} / \mathrm{L}$ or less, but occasionally were between 0.25 and $0.50 \mu \mathrm{g} / \mathrm{L}$. Atrazine concentrations in water from the deep monitoring wells increased when artificial recharge by injection began. Concentrations were variable, occasionally in the range of 0.1 to $0.2 \mu \mathrm{g} / \mathrm{L}$.

The median arsenic concentration in the recharge (diversion well) water for the Halstead recharge site was $20 \mu \mathrm{g} / \mathrm{L}$. Arsenic concentrations in water samples from the shallow monitoring wells did not increase because of artificial recharge despite the large arsenic concentrations in the recharge water. Ferric oxyhydroxide precipitates observed in the recharge basins and recharge trench may have sorbed or co-precipitated arsenic. Arsenic concentrations in samples from deep monitoring well DMW-H13 remained relatively constant (approximately $10 \mu \mathrm{g} / \mathrm{L}$ ) with no apparent change because of recharge activities. Arsenic concentrations in samples from deep monitoring well DMW-H1 increased to about $20 \mu \mathrm{g} / \mathrm{L}$ after injection recharge began, which was attributed to conservative transport of arsenic in the injected recharge (diversion well) water. 
Iron concentrations in water samples from the shallow monitoring wells at the Halstead recharge site were substantially less than the USEPA SDWR of $300 \mu \mathrm{g} / \mathrm{L}$. Iron concentrations in water samples from deep monitoring well DMW$\mathrm{H} 1$ increased steadily to larger than $200 \mu \mathrm{g} / \mathrm{L}$ after artificial recharge by direct injection began and is attributed to conservative transport of iron in the injected recharge (diversion well) water. Iron concentrations in the water sampled from deep monitoring well DMW-H13 increased after injection recharge began to levels substantially larger than iron concentrations in the recharge water. This mobilization of iron could be caused by reduction of ferric oxyhydroxides, increased bacterial activity, or some other change in the geochemical environment related to the injection of recharge water.

Saturation indices for calcite and dolomite for prerecharge water samples from monitoring wells at the Halstead recharge site indicate limited carbonate minerals in the aquifer sediments at the site; therefore, increases in saturation indices probably were related to changes in water chemistry caused by mixing of the aquifer water with the recharge water rather than dissolution of carbonate minerals. Ferric oxyhydroxide precipitates on the recharge basin and trench floors at the Halstead recharge site demonstrate that the recharge (diversion well) water, when contacted by oxygen from the atmosphere, will precipitate ferric oxyhydroxides.

Direct diversion of water from the Little Arkansas River was used to capture flows greater than base flow for the Sedgwick recharge system. The stream water was treated to reduce turbidity and organic compounds and piped to the Sedgwick recharge site for artificial recharge through surface-spreading recharge basins.

Chloride concentrations in water samples from the shallow monitoring wells at the Sedgwick recharge site increased after artificial recharge operations began. Chloride concentrations in one deep monitoring well did not change because of artificial recharge activities, whereas chloride concentrations decreased in the other deep monitoring well, which may indicate the displacement of deep aquifer water by shallow aquifer water as water in the shallow aquifer is in turn displaced by recharge water.

Annual averages calculated from estimated daily atrazine concentrations for the Little Arkansas River at Sedgwick did not exceed the USEPA MCL of $3.0 \mu \mathrm{g} / \mathrm{L}$ (as an annual average) from 1999 through 2004. Atrazine concentrations in the treated diverted stream water exceeded $3.0 \mu \mathrm{g} / \mathrm{L}$ in three discrete samples. At the Sedgwick recharge site, atrazine concentrations increased in water sampled from both shallow monitoring wells after artificial recharge began. Atrazine was not detected in water sampled from the deep monitoring wells at this site.

Arsenic concentrations were less than $5.0 \mu \mathrm{g} / \mathrm{L}$ in all water samples from the monitoring wells at the Sedgwick recharge site. Arsenic concentrations did not change during recharge operations, indicating that the artificial recharge did not mobilize arsenic. Iron concentrations were small in water sampled from all monitoring wells at the Sedgwick recharge site.

Saturation indices calculated for water sampled from the shallow monitoring wells at the Sedgwick recharge site indicate carbonate minerals probably are not present in the shallow part of the aquifer. However, calcite may be reacting in the deeper part of the aquifer to produce saturations indices that approach equilibrium.

Simulations to model injection of treated stream water into the Equus Beds aquifer were conducted using PHREEQC. These simulations examined the effects of mixing treated stream water with deep ground water on the saturation indices of calcite and amorphous ferric oxyhydroxide. Results of the simulations indicate that calcite oversaturation is likely only for mixtures that are greater than 90 percent recharge water. Calcite precipitation could reduce permeability and reduce effectiveness of artificial recharge. Amorphous ferric oxyhydroxide oversaturation is possible in all mixtures of the two waters. In addition, iron bacteria could be a cause for concern for injection of oxygenated water into the aquifer. It is possible that biofouling of the injection well could occur causing increased precipitation of iron and creation of a biofilm associated with iron bacteria activity. The precipitation and biofouling could decrease the efficiency of the injection well as well as reduce the permeability of the aquifer material in vicinity of the well.

\section{References Cited}

Aucott, W.R., Myers, N.C., and Dague, B.J., 1998, Status of ground-water levels and storage in the Wichita well field area, south-central Kansas, 1997: U.S. Geological Survey Water-Resources Investigations Report 98-4095, 15 p.

Burns and McDonnell, 1996, Equus Beds Groundwater Recharge Demonstration Project: Kansas City, Missouri, Burns and McDonnell Engineering Consultants, prepared for the city of Wichita Water and Sewer Department, various pagination.

Christensen,V.G., Jian, Xiaodong, and Ziegler, A.C., 2000, Regression analysis and real-time water-quality monitoring to estimate constituent concentrations, loads, and yields in the Little Arkansas River, south-central Kansas, 1995-99: U.S. Geological Survey Water-Resources Investigations Report 00-4126, 36 p.

Christensen, V.G., Ziegler, A.C., Rasmussen, P.P., and Jian, Xiaodong, 2003, Continuous real-time water-quality monitoring of Kansas streams, in Proceedings of 2003 Spring Specialty Conference on Agricultural Hydrology and Water Quality, May 12-14, 2003, Kansas City, Missouri: Middleburg, Virginia, American Water Resources Association, AWRA Technical Publication Series No. TPS-03-1, compact disc. 
Drever, J.L., 1997, The geochemistry of natural waters-surface and groundwater environments (3rd ed.): Upper Saddle River, New Jersey, Prentice Hall, 436 p.

Fetter, C.W., 1994, Applied hydrogeology: Englewood Cliffs, New Jersey, Prentice Hall, 517 p.

Fischer, H.B., List, E.J., Koh, R.C.Y., Imberger, J., and Brooks, N.H., 1979, Mixing in inland and coastal waters: New York, Academic Press, Inc., 483 p.

Garbarino, J.R., Bednar, A.J., and Burkhardt, M.R., 2002, Methods of anaysis by the U.S. Geological Survey National Water Quality Laboratory-arsenic speciation in naturalwater samples using laboratory and field methods: U.S. Geological Survey Water-Resources Investigations Report 02-4144, 47 p.

Guo, T.Z., DeLaune, R.D., and Patrick, W.H., 1997, The influence of sediment redox chemistry on chemically active forms of arsenic, cadmium, chromium, and zinc in estuarine sediment: Environmental International v. 23, p. 305-316.

Hansen, C.V., 1991, Estimates of freshwater storage and potential natural recharge for principal aquifers in Kansas: U.S. Geological Survey Water-Resources Investigations Report 87-4230, 100 p.

Hansen, C.V., and Aucott, W.R., 2004, Status of ground-water levels and storage volume in the Equus Beds aquifer near Wichita, Kansas, January 2000-January 2003: U.S. Geological Survey Water-Resources Investigations Report 03-4298, 36 p.

Helsel, D.R., and Hirsch, R.M., 1992, Statistical methods in water resources: New York, Elsevier, 522 p.

Hem, J.D., 1992, Study and interpretation of chemical characteristics of natural water ( 3 rd ed.): U.S. Geological Survey Water-Supply Paper 2254, 263 p.

Hinkle, S.R., and Polette, D.J., 1999, Arsenic in ground water of the Willamette Basin, Oregon: U.S. Geological Survey Water-Resources Investigations Report 98-4205, 29 p.

Juracek, K.E., and Hansen, C.V., 1995, Digital maps of the extent, base, top, and 1991 potentiometric surface of the High Plains aquifer in Kansas: U.S. Geological Survey Open-File Report 95-758, map scales 1:500,000 and $1: 100,000$.

Koterba, M.T., Wilde, F.D., and Lapham, W.W., 1995, Ground-water data-collection protocols and procedures for the National Water-Quality Assessment Program—collection and documentation of water-quality samples and related data: U.S. Geological Survey Open-File Report 95-399, 113 p.
Myers, N.C., Haragadine, G.D., and Gillespie, J.B., 1996, Hydrologic and chemical interactions of the Arkansas River and the Equus Beds aquifer between Hutchinson and Wichita, south-central Kansas: U.S. Geological Survey Water-Resources Investigations Report 95-4191, 100 p.

National Oceanic and Atmospheric Administration, 1998, Climatological data, annual summary, Kansas, 1997: Asheville, North Carolina, v. 111, no. 13, 35 p.

National Oceanic and Atmospheric Administration, 1999, Climatological data, annual summary, Kansas, 1998: Asheville, North Carolina, v. 112, no. 13, 31 p.

National Oceanic and Atmospheric Administration, 2000, Climatological data, annual summary, Kansas, 1999: Asheville, North Carolina, v. 111, no. 13, 35 p.

National Oceanic and Atmospheric Administration, 2001, Climatological data, annual summary, Kansas, 2000: Asheville, North Carolina, v. 114, no. 13, 33 p.

National Oceanic and Atmospheric Administration, 2002, Climatological data, annual summary, Kansas, 2001: Asheville, North Carolina, v. 115, no. 13, 36 p.

National Oceanic and Atmospheric Administration, 2003, Climatological data, annual summary, Kansas, 2002: Asheville, North Carolina, v. 116, no. 13, 32 p.

National Oceanic and Atmospheric Administration, 2004, Climatological data, annual summary, Kansas, 2003: Asheville, North Carolina, v. 117, no. 13, 32 p.

National Oceanic and Atmospheric Administration, 2005a, Climatological data, annual summary, Kansas, 2004: Asheville, North Carolina, v. 118, no. 13, 32 p.

National Oceanic and Atmospheric Administration, 2005b, Daily precipitation data for United States cooperative and National Weather Service sites: Asheville, North Carolina, North Climatic Data Center, accessed February 21, 2006, at http://www.ncdc.noaa.gov/oa/climate/stationlocator.html

Parkhurst, D.L., and Appelo, C.A.J, 1999, User's guide to PHREEQC (version 2) - a computer program for speciation, batch-reaction, one-dimensional transport, and inverse geochemical calculations: U.S. Geological Survey WaterResources Investigations Report 99-4259, 312 p.

Parkhurst, D.L., Engesgaard, P., and Kipp, K.L., 1995, Coupling the geochemical model PHREEQC with a 3D multicomponent solute-transport model, in V.M. Goldschmidt Conference, State College, Pennsylvania: Program and Abstracts, p. 77-78. 
Parkhurst, D.L., and Kipp, K.L., 2002, Parallel processing for PHAST - a three-dimensional reactive-transport simulator, in Hassanizadeh, S.M., Schotting, R.J., Gray, W.G., and Pinder, G.F., eds., Developments in water science-computational methods in water resources: Amsterdam Elsevier, no. 47 , v. 1 , p. $711-718$.

Parkhurst, D.L., Kipp, K.L., Engesgaard, P., and Charlton, S.R., 2004, PHAST - a program for simulating groundwater flow, solute transport, and multicomponent geochemical reactions: U.S. Geological Survey Techniques and Methods, book 6, chap. A8, 154 p.

Piper, A.M., 1944, A graphic procedure in the geochemical interpretation of water analyses: American Geophysical Union Transactions, v. 25, p. 914-923.

Poeter, E.P., and Hill, M.C., 1998, Documentation of UCODE, a computer code for universal inverse modeling: U.S. Geological Survey Water-Resources Investigations Report 98-4080, 116 p.

Poeter, E.P., Hill, M.C., Banta, E.R., Mehl, Steffen, and Christensen, Steen, 2005, UCODE_2005 and six other computer codes for universal sensitivity analysis, calibration, and uncertainty evaluation: U.S. Geological Survey Techniques and Methods, book 6, chap. A11, 283 p.

Puls, R.W., and Barcelona, M.J., 1996, Low-flow (minimal drawdown) ground-water sampling procedures: U.S. Environmental Protection Agency, Ground Water Issue, EPA 540/S-95/504, April 1996, 12 p.

Ross, J.A., compiler, 1991, Geologic map of Kansas: Kansas Geological Survey Map M-23, 1 sheet, scale 1:500,000.

Smedley, P.L., and Kinniburgh, D.G., 2002, A review of the source, behavior, and distribution of arsenic in natural waters: Applied Geochemistry, v. 17 no. 5, p. 517-568.

U.S. Department of Agriculture, 2002a, 2002 Census of agriculture county profile, Harvey, Kansas: U.S. Department of Agriculture, National Agricultural Statistics Service, information available on Web, accessed June 16, 2005, at http://www.nass.usda.gov/census/census02/profiles/ks/ cp20079.PDF

U.S. Department of Agriculture, 2002b, 2002 Census of agriculture county profile, Sedgwick, Kansas: U.S. Department of Agriculture, National Agricultural Statistics Service, information available on Web, accessed June 16, 2005, at http://www.nass.usda.gov/census/census02/profiles/ks/ cp20173.PDF

U.S. Environmental Protection Agency, 2004, 2004 edition of the drinking water standards and health advisories: U.S. Environmental Protection Agency, Report EPA 822-R04-005, winter 2004, information available on the Web, accessed July 10, 2005, at http://www.epa.gov/waterscience/ drinking/standards/dwstandards.pdf
U.S. Geological Survey, 2006, U.S. Geological Survey Standard Reference Sample Project-Performance Evaluation of Analytical Labortories: U.S. Geological Survey, Branch of Quality Systems, information available on Web, accessed on August 21, 2006, at http://bqs.usgs.gov/srs/FactSheet.htm

Wagner, R.J., Mattraw, H.C., Ritz, G.F., and Smith, B.A., 2000, Guidelines and standard procedures for continuous water-quality monitors - site selection, field operation, calibration, record computation, and reporting: U.S. Geological Survey Water-Resources Investigations Report 2000-4252, $53 \mathrm{p}$.

Ward, J.R., and Harr, C.A., eds., 1990, Methods for collection and processing of surface-water and bed-material samples for physical and chemical analysis: U.S. Geological Survey Open-File Report 90-140, 79 p.

Warren, D.R., Blain, G.T., Shorney, F.L, and Klein, L.J., 1995, IRP - a case study from Kansas: Journal of the American Water Works Association, June 1995, p. 57-71.

Welch, A.H., Westjohn, D.B., Helsel, D.R., and Wanty, R.B., 2000, Arsenic in ground water of the United States - occurrence and geochemistry: Ground Water, v. 38, no. 4, p. 589-604.

Wilde, F.D., and Radke, D.B., eds., 1998, Field measurements, in National field manual for the collection of water-quality data: U.S. Geological Survey Techniques of Water-Resource Investigations, book 9, chap. A6, p. 3-20.

Williams, C.C., and Lohman, S.W., 1949, Geology and ground-water resources of a part of south-central Kansas with special reference to the Wichita municipal water supply: Kansas Geological Survey Bulletin 79, 455 p.

Wood, W.W., 1976, Guidelines for collection and field analysis of ground-water samples for selected unstable constituents: U.S. Geological Survey Techniques of Water-Resources Investigations, book 1, chap. D2, 24 p.

Ziegler, A.C., Christensen, V.G., and Ross, H.C., 1999, Baseline water-quality and preliminary effects of artificial recharge on ground water, south-central Kansas, 1995-98: U.S. Geological Survey Water-Resources Investigations Report 99-4250, 74 p.

Ziegler, A.C., and Combs, L.J., 1997, Baseline data-collection and quality control protocols and procedures for the Equus Beds Ground-Water Recharge Demonstration Project near Wichita, Kansas, 1995-96: U.S. Geological Survey OpenFile Report 97-235, 57 p.

Ziegler, A.C., Ross, H.C., Trombley, T.J., and Christensen, V.G., 2001, Effects of artificial recharge on water quality in the Equus Beds aquifer, south-central Kansas, 1995-2000: U.S. Geological Survey Fact Sheet 096-01, 4 p. 
Prepared by Lawrence Publishing Service Center. Edited by Lanna Combs.

Graphics by Jeff Hartley and Michael Kemppainen. Layout and design by Michael Kemppainen.

For more information concerning the research described in this report, contact:

U.S. Geological Survey

4821 Quail Crest Place

Lawrence, KS 66049

(785) 842-9909

http://ks.water.usgs.gov 


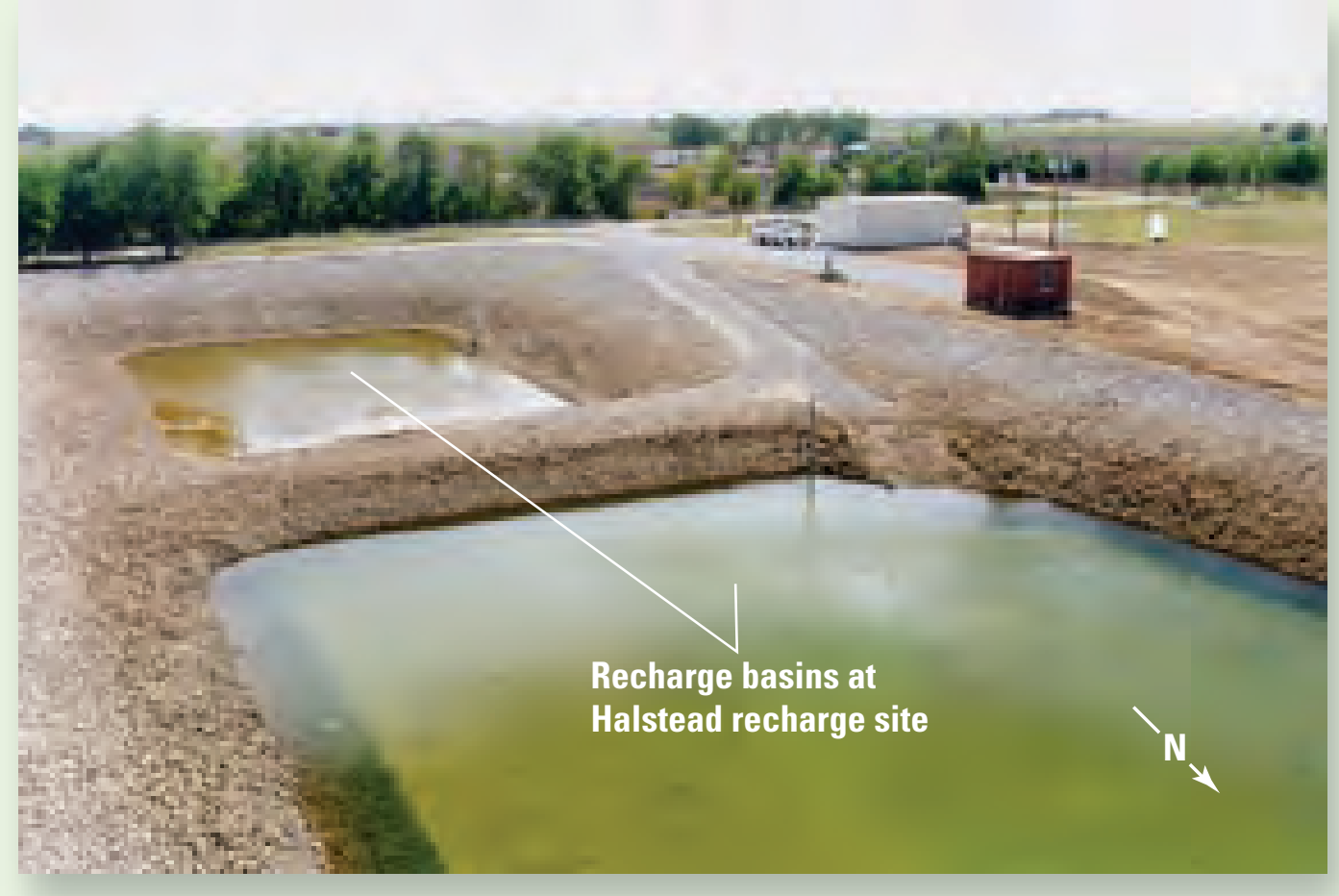

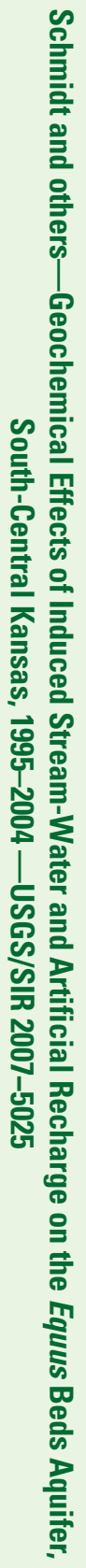

9 Printed on recycled paper 